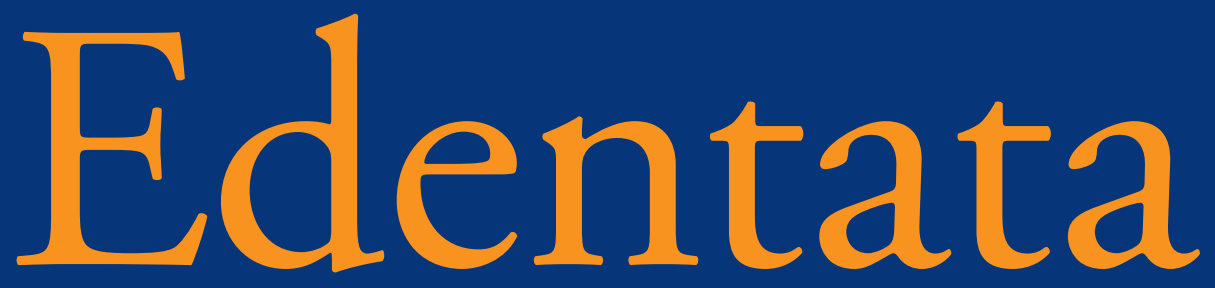

The Newsletter of the IUCN/SSC Anteater, Sloth and Armadillo Specialist Group

December $2021 \bullet$ Number 22
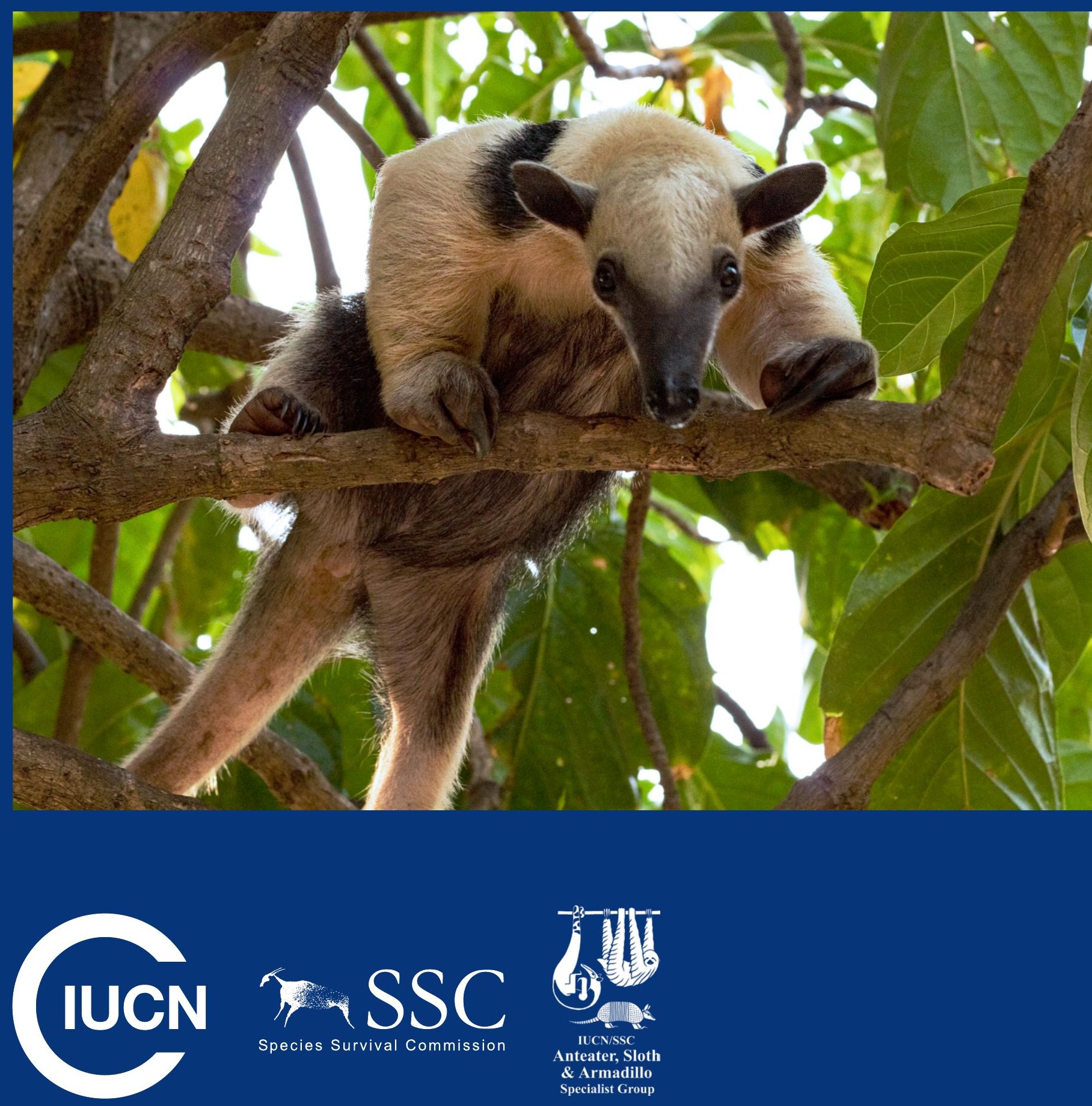

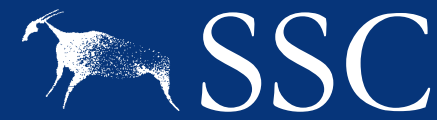

Species Survival Commission

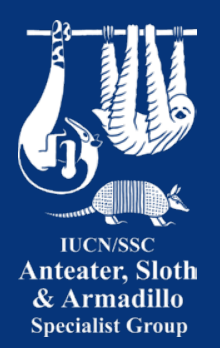




\section{Edentata}

The Newsletter of the IUCN/SSC Anteater, Sloth and Armadillo Specialist Group

ISSN 1413-4411 (print version)

ISSN 1852-9208 (electronic version)

http://www.xenarthrans.org

Editors:

Mariella Superina, IMBECU, CCT CONICET Mendoza, Mendoza, Argentina.

Nadia de Moraes-Barros, Centro de Investigação em Biodiversidade e Recursos Genéticos, Universidade de Porto, CIBIO-InBIO, Porto, Portugal.

Agustín M. Abba, Centro de Estudios Parasitológicos y de Vectores, CCT CONICET La Plata-UNLP, La Plata, Argentina.

Associate editors:

W. Jim Loughry, Valdosta State University, Valdosta, GA, USA.

Roberto F. Aguilar, Adjunct Senior Lecturer-Wildbase-Massey University, New Zealand (ret.).

Editorial assistance:

Alessandra Bertassoni, Universidade Federal de Goiás, Brazil.

IUCN/SSC Anteater, Sloth and Armadillo Specialist Group Chair

Mariella Superina

IUCN/SSC Anteater, Sloth and Armadillo Specialist Group Deputy Chair

Nadia de Moraes-Barros

\section{Layout:}

Gabriela F. Ruellan, Designer in Visual Communication.

The editors wish to thank all reviewers for their collaboration.

Front Cover image:

Southern Tamandua (Tamandua tetradactyla), Parnaíba, Piauí, Brazil.

Photo: Karina Theodoro Molina, Instituto Tamanduá.

Please direct all submissions and other editorial correspondence to:

Mariella Superina

IMBECU, CCT CONICET Mendoza

Casilla de Correos 855, Mendoza (5500), Argentina

Tel. +54 261-5244160

Fax +54 261-5244001

E-mail: edentata@xenarthrans.org

IUCN/SSC Anteater, Sloth and Armadillo Specialist Group logo courtesy of Stephen D. Nash, 2009.
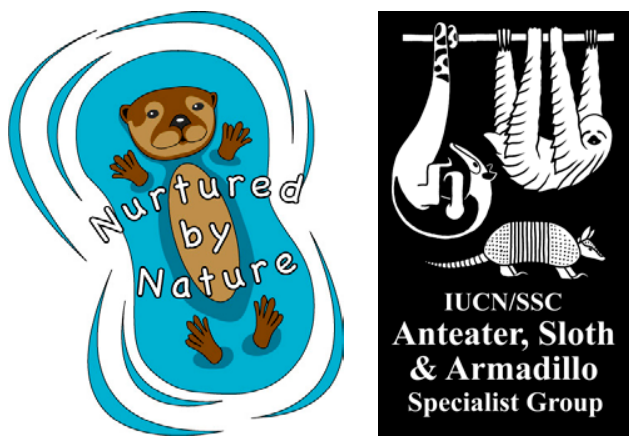


\section{Table of Contents}

Letter from the Editors

\section{ARTICLES}

Diversity and variation of dorsal carapace structures in the giant armadillo Priodontes maximus (Kerr, 1792) and their potential use for individual identification

Daniel Barasoain, Pedro Cuaranta \& Romina Adela Mauriño

First estimates of potential lifespan of giant armadillo (Priodontes maximus) in the wild 9

Arnaud Leonard Jean Desbiez, Duston Larsen, Gabriel Favero Massocato, Nina Attias, Danilo Kluyber \& Damián I. Rumiz

Distribution, ecology, and conservation of Xenarthra in Bolivia - update to 2021

Enzo Aliaga-Rossel, Carmen Julia Quiroga, Ximena Velez-Liendo, Alfredo Romero-Muñoz, Zulia Porcel, Robert Benedict Wallace, Guido Marcos Ayala, María Estela Viscarra, Erika Cuéllar Soto, Teresa Tarifa \& Andrew Noss

\section{SHORT COMMUNICATIONS}

Novo registro de Myrmecophaga tridactyla Linnaeus, 1758 (Mammalia: Xenarthra) no estado do Rio Grande do Sul, Brasil

Karyne Fayes Sharara, Lucas Adriano Pachla, Marthoni Vinicius Massaro \& David Augusto Reynalte-Tataje

First records of the seven-banded armadillo (Dasypus septemcinctus) and the six-banded armadillo (Euphractus sexcinctus) in northwestern Bolivia.

Guido Marcos Ayala, María Estela Viscarra \& Robert Benedict Wallace

Primeiro registro de Myrmecophaga tridactyla (Pilosa, Myrmecophagidae) na região norte do Paraná, Brasil.... 47 Marcelo Okamura Arasaki, Alan Deivid Pereira, Marcelo Hideki Shigaki Yabu, Cleber Gustavo de Góes \& Eduardo Issberner Panachão

Record of the silky anteater (Cyclopes didactylus; Xenarthra: Cyclopedidae) in the Atlantic Forest of Rio Grande do Norte state, northeastern Brazil .

Paulo Henrique Dantas Marinho, Luiz Yoshihiro Garcia de Lima Hagi, Bruno Rodrigo de Albuquerque França \& Liana Mara Mendes de Sena

News 


\section{Letter from the Editors}

\section{Dear readers,}

Welcome to a new edition of our Journal and Newsletter! Edentata 22 features three full articles and four short communications. It includes a great review of the distribution, ecology, and conservation of Xenarthra in Bolivia; first estimates of the potential lifespan of giant armadillos; and a description of the variations of dorsal carapace structures in giant armadillos that can be useful for their individual identification. You will also find new distribution records for armadillos in northwestern Bolivia, giant anteaters in southern Brazil, and silky anteaters in northeastern Brazil.

The News section is packed with interesting information, including the announcement of a new partnership our Specialist Group has entered with the Foundation for International Aid to Animals (FIAA). Following the IUCN's focus on increasing diversity among SSC members, we have decided to prioritize the inclusion of new members from countries that were not yet represented in our Specialist Group. We are excited that we found excellent candidates from seven underrepresented range countries!

This year we also initiated several subcommittees. You will find a detailed description of the criteria our taxonomy subcommittee has established to evaluate newly proposed changes in xenarthran taxonomy, as well as a list of topics on which our education/outreach subcommittee is focusing. In this context, we are happy to inform you that we are on Instagram (huge thanks to Alessandra Bertassoni for taking care of our social media!), and that we have set up a website for the Pygmy sloth conservation project.

The News section also includes sad news about the passing away of two great researchers, our long-time Specialist Group member Teresa Cristina da Silveira Anacleto and François Catzeflis. Both were dedicated, inspiring researchers. Teresa and François will sorely be missed.

We would like to take the opportunity to thank all our members for their tireless work and enthusiasm, and our partner institutions Nurtured by Nature and FIAA for their continuing support. 


\section{IUCN SSC Anteater, Sloth and Armadillo Specialist Group Members 2021-2025}

\section{Chair}

Mariella Superina, Dr.med.vet., Ph.D. in

Conservation Biology

Research Scientist CONICET

Associate Researcher Fundación Omacha

IMBECU, CCT CONICET Mendoza

Casilla de Correos 855

Mendoza (5500)

Argentina

E-mail:mariella@superina.ch

\section{Deputy Chair}

Nádia de Moraes-Barros, Ph.D. in Biology

(Genetics)

CiBIO - Centro de Investigação em

Biodiversidade e Recursos Genéticos/InBIO

Laboratório Associado

Universidade do Porto

Campus Agrário de Vairão

Rua Padre Armando Quintas

4485-661 Vairão

Portugal

E-mail: nadiabarros@cibio.up.pt

\section{Red List Authority}

Agustín M. Abba, Doctor in Natural Science

Research Scientist CONICET

Centro de Estudios Parasitológicos y Vectores (CEPAVE)

CCT - CONICET La Plata - UNLP

Bv. 120 S/N entre Avenida 60 y Calle 64

La Plata (1900)

Argentina

E-mail:abbaam@yahoo.com.ar
Members

Agustín M. Abba, Argentina

Roberto Aguilar, Mexico

Adriana Aguilar Borbón, Costa Rica

Enzo Aliaga-Rossel, Bolivia

María Clara Arteaga, Mexico

Alessandra Bertassoni, Brazil

Adriano Chiarello, Brazil

Benoit De Thoisy, French Guyana

Frédéric Delsuc, France

Erin Earl, Guyana

Gustavo A. B. da Fonseca, USA

Enrique Gonzalez, Uruguay

Jutta Heuer, Germany

Rachel Hoffmann, United Kingdom

Jim Loughry, USA

Colleen McDonough, USA

Dennis A. Meritt Jr., USA

Flávia Miranda, Brazil

Nadia Moraes-Barros, Brazil/Portugal

Andrew Noss, USA

Rominna Pasutti, Chile

Tinka Plese, Colombia

Monique Pool, Suriname

Virgilio G. Roig, Argentina

Ilona Schappert, Germany

Diorene Smith, Panama

Paul Smith, Paraguay

Mariella Superina, Argentina

Manfredo Turcios, Honduras

Sergio F. Vizcaíno, Argentina

Bryson Voirin, USA 


\title{
Diversity and variation of dorsal carapace structures in the giant armadillo Priodontes maximus (Kerr, 1792) and their potential use for individual identification
}

\author{
Daniel Barasoain $^{\text {A,1 }}{ }^{\text {, Pedro Cuaranta }}{ }^{\mathrm{A}, \mathrm{B}}$ \& Romina Adela Mauriño ${ }^{\mathrm{B}}$
}

\author{
A Laboratorio de Evolución de Vertebrados y Ambientes Cenozoicos, \\ Centro de Ecología Aplicada del Litoral (UNNE-CONICET) y Cátedra de Paleontología, \\ Facultad de Ciencias Exactas, Naturales y Agrimensura, Universidad Nacional del Nordeste, RP5, 3400, Corrientes, Argentina

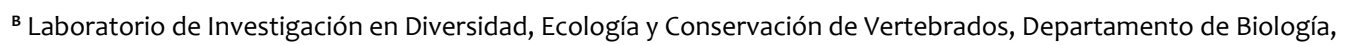 \\ Facultad de Ciencias Exactas, Naturales y Agrimensura, Universidad Nacional del Nordeste, \\ Av. Libertad 5470, 3400, Corrientes, Argentina \\ E-mail: cuaranta2004@yahoo.com.ar (PC); romina.maurio@yahoo.com (RAM) \\ ${ }^{1}$ Corresponding author \\ E-mail: danielbarasoain@gmail.com
}

\begin{abstract}
Dorsal carapace and osteoderm morphological features have traditionally been widely used in both extinct and extant armadillo systematics. However, the intraspecific variability at the carapace level represents a little studied aspect. In this contribution, we analyzed several dorsal carapaces of Priodontes maximus with the purpose of recording such variability. As a result, we describe a total of seven structures concerning the dorsal carapace osteoderm configuration, including distinct terminations of the osteoderm rows, and the most frequent aberrant shapes of the osteoderms. Though the same type of structure can be usually found in several specimens, its frequency and precise location within the carapace are unique to each individual. In this sense, besides improving anatomical descriptions, the identification of these structures can be potentially implemented as a complementary method to help recognize specific individuals being tracked. Moreover, it can represent a very effective recognition method even a long time after death. Given the general decreasing trend of P. maximus populations, it is important to develop as many monitoring tools as possible, in order to support conservation programs for this species.
\end{abstract}

Keywords: Cingulata, osteoderms, morphology, variability

Diversidad y variación de estructuras en la coraza dorsal del armadillo gigante Priodontes maximus (Kerr, 1792) y su potencial uso para la identificación de individuos

Resumen Las características morfológicas de la coraza dorsal y de los osteodermos han sido tradicionalmente muy utilizadas en la sistemática de armadillos, tanto extintos como actuales. Sin embargo, la variabilidad intraespecífica a nivel de coraza ha sido muy poco tratada en la literatura. En este trabajo se analiza una serie de corazas dorsales pertenecientes a Priodontes maximus con el objetivo de registrar dicha variabilidad. Como resultado, se describen un total de siete estructuras presentes en la configuración de osteodermos que conforman la coraza dorsal, incluyendo distintas terminaciones de las hileras de osteodermos, y las formas de osteodermos aberrantes más frecuentes. A pesar de que el mismo tipo de estructura puede estar presente en distintos ejemplares, su frecuencia y localización en la coraza son únicas de cada individuo. De esta manera, además de mejorar las descripciones anatómicas, la identificación de estas estructuras puede ser potencialmente implementada como un método complementario para reconocer individuos a los que se esté realizando un seguimiento. Además, también puede suponer un método de reconocimiento efectivo incluso pasado un largo tiempo tras la muerte del individuo. Dada la tendencia general a la disminución de las poblaciones de P. maximus, resulta importante desarrollar el mayor número posible de herramientas de monitoreo que puedan ayudar a los programas de conservación de esta especie.

Palabras clave: Cingulata, morfología, osteodermos, variabilidad 


\section{INTRODUCTION}

The giant armadillo Priodontes maximus (Kerr, 1792) of the subfamily Tolypeutinae (Xenarthra, Cingulata, Chlamyphoridae), has a wide distribution over most of South America, including habitats that range from tropical forests to open savannas (Abba \& Superina, 2010). However, despite having such a wide geographical distribution, it is rare even in environments considered as "pristine" (Meritt, 2006), and is currently classified as Vulnerable by the IUCN Red List of Threatened Species (Anacleto et al., 2014).

As reflected by its common name, it is the largest living representative of the order Cingulata ("armored xenarthrans"), reaching a total length of $150 \mathrm{~cm}$ and a body weight of up to $50 \mathrm{~kg}$ (Emmons \& Feer, 1997; Nowak, 1999; Carter et al., 2016; Desbiez et al., 2019). It is a very efficient burrower with mainly nocturnal habits (Noss et al., 2004; Silveira et al., 2009), and its diet predominantly consists of

TABLE 1. List of specimens analyzed in this work.

\begin{tabular}{|c|c|c|c|}
\hline Museum/collection & Specimen & Anatomical element & Geographic provenance \\
\hline $\begin{array}{l}\text { American Museum of Natural History, } \\
\text { New York, United States }\end{array}$ & AMNH-147493 & Complete dorsal carapace & - \\
\hline $\begin{array}{c}\text { Colección Mamíferos, } \\
\text { Facultad de Ciencias Naturales }\end{array}$ & CML-06228 & $\begin{array}{l}\text { Complete skull and dorsal } \\
\text { carapace }\end{array}$ & Chaco Province, Argentina \\
\hline $\begin{array}{c}\text { e Instituto Miguel Lillo, } \\
\text { San Miguel de Tucumán, Argentina }\end{array}$ & CML-00137 & Complete dorsal carapace & Chaco Province, Argentina \\
\hline $\begin{array}{l}\text { Museo Municipal de Ciencias Naturales } \\
\text { Carlos Darwin, Punta Alta, Argentina }\end{array}$ & MD- & Complete dorsal carapace & - \\
\hline \multirow{15}{*}{$\begin{array}{l}\text { Museo Ciencias Naturales } \\
\text { Augusto Schulz, Resistencia, Argentina }\end{array}$} & - & Taxidermy specimen & Chaco province, Argentina \\
\hline & - & Taxidermy specimen & Chaco province, Argentina \\
\hline & - & Taxidermy specimen & Chaco province, Argentina \\
\hline & - & $\begin{array}{c}\text { Partial skeleton and complete } \\
\text { dorsal carapace }\end{array}$ & Chaco Province, Argentina \\
\hline & - & Complete dorsal carapace & Chaco Province, Argentina \\
\hline & - & Complete dorsal carapace & Chaco Province, Argentina \\
\hline & - & Complete dorsal carapace & Chaco Province, Argentina \\
\hline & - & Complete dorsal carapace & Chaco Province, Argentina \\
\hline & - & Complete dorsal carapace & - \\
\hline & - & Complete dorsal carapace & - \\
\hline & - & Complete dorsal carapace & - \\
\hline & - & Complete dorsal carapace & - \\
\hline & - & Complete dorsal carapace & - \\
\hline & - & Complete dorsal carapace & - \\
\hline & - & Complete dorsal carapace & - \\
\hline $\begin{array}{l}\text { Laboratorio de Paleontología de Verte- } \\
\text { brados (CECOAL-UNNE-CONICET), } \\
\text { Corrientes, Argentina }\end{array}$ & LPV-CO-56 & $\begin{array}{c}\text { Dessicated specimen, partially } \\
\text { complete skeleton and complete } \\
\text { dorsal carapace }\end{array}$ & Chaco Province, Argentina \\
\hline
\end{tabular}


ants and termites (Redford, 1985; Eisenberg \& Redford, 1999). Each individual carapace presents a unique dark to light color pattern (Noss et al., 2004), and is composed of a scapular and a pelvic shield separated by a variable number (11-13) of mobile bands (Nowak, 1999).

The dorsal carapace composed by hundreds of osteoderms is the main morphological feature that characterizes all cingulates (Gaudin \& McDonald, 2008), and is believed to have strongly influenced the evolutionary history of the group (Superina \& Loughry, 2012). As is the case with P. maximus, the carapace of all current armadillos can be divided into the same three well-differentiated portions (a scapular and a pelvic shield separated by a variable number of mobile bands), which provide greater limb and body flexibility. However, extinct cingulates developed a huge variety of carapace configurations. Among them, Eutatini armadillos (Euphractinae) are characterized by presenting a very rudimentary pseudo-scapular shield (Krmpotic et al., 2009), and some extinct euphractine armadillos such as those belonging to the genus Prozaedyus Ameghino (1891) even developed a dorsal carapace that was composed just by mobile bands and a pelvic shield (Barasoain et al., 2020). In turn, glyptodonts (Glyptodontidae) developed an undivided and rigid dorsal carapace composed by fixed osteoderms only (Zurita et al., 2016).

The study of the dorsal carapace and osteoderm features has been traditionally considered as a valuable tool in both extinct and extant armadillo systematics. Moreover, the development in each species of a unique ornamentation pattern on the exposed surface of both the fixed and mobile osteoderms that compose the carapace has generated specific terminology that applies to each morphological character at the osteoderm level (Soibelzon et al., 2010).

Intraspecific morphological variation at the carapace level has, however, not been studied. Our observations suggest that a high percentage of $P$. maximus individuals present a series of distinctive structures in the osteoderm configuration that compose their dorsal carapace. The purpose of this contribution is to compile, describe, and illustrate the main types of these structures present over a sample of carapaces belonging to the extant $P$. maximus. The proper characterization of these structures will serve to guide more comprehensive anatomical descriptions of both fossil and extant armadillo individuals. Moreover, given that carapaces can persist for a long time in natural environments, the previous documentation of these structures may provide a useful tool for the identification of specific individuals being monitored or under study even a long time after death.

\section{MATERIALS AND MethodS}

This study is based on the analysis of several dorsal carapaces and taxidermy individuals belonging to the species Priodontes maximus, housed in several museums (TABLE 1). Each kind of structure identified is named, described in detail, and illustrated.

Since most of the samples consist of isolated carapaces with no available information on whether they belonged to a male or female individual or about their geographic provenance, these variables were not taken into consideration. In order to describe the structures, we consider as complete those rows of osteoderms that originate at one lateral border of the carapace and extend without interruption until they reach the opposite border. In turn, we consider as incomplete those rows of osteoderms that originate at one lateral border of the carapace and do not reach the opposite border, or that do not originate on either of the two lateral borders.

\section{RESULTS}

After a detailed morphological analysis carried out on the scapular shield, mobile bands, and pelvic shield of the dorsal carapace of a total of 23 $P$. maximus adult individuals, we identified a total of seven distinct structures (FIG. 1).

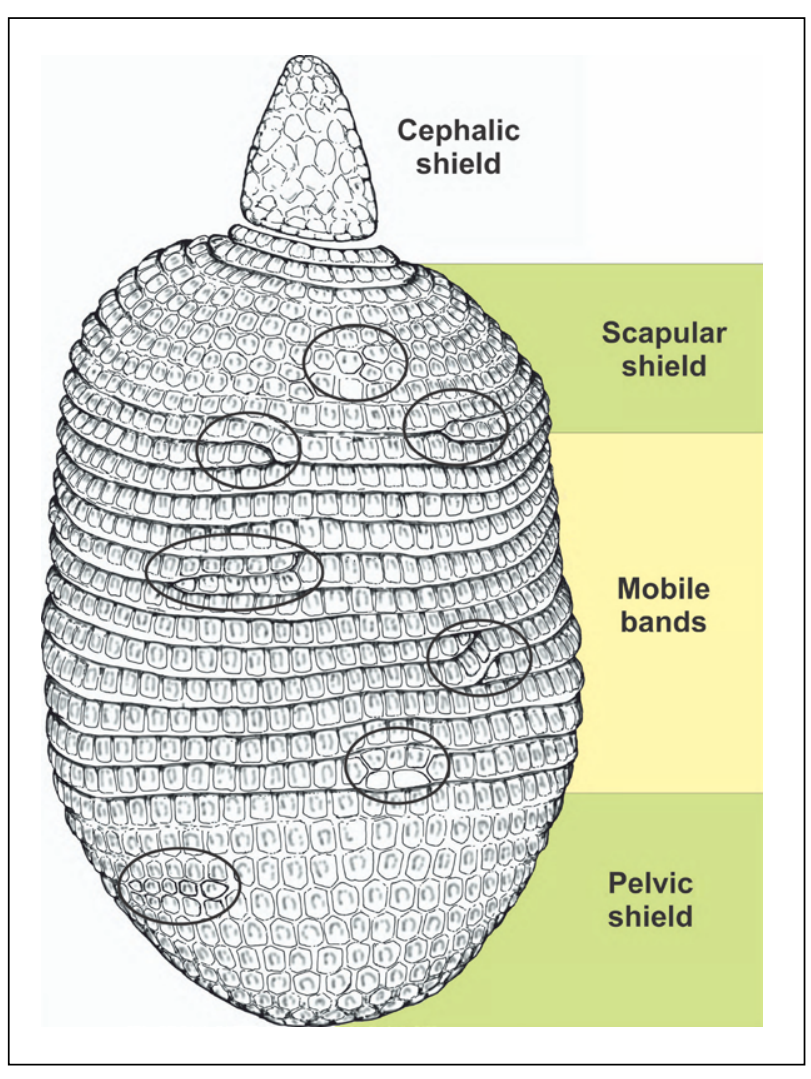

FIGURE 1. Division of the dorsal carapace of Priodontes maximus. Black ovals indicate examples of the structures identified. 

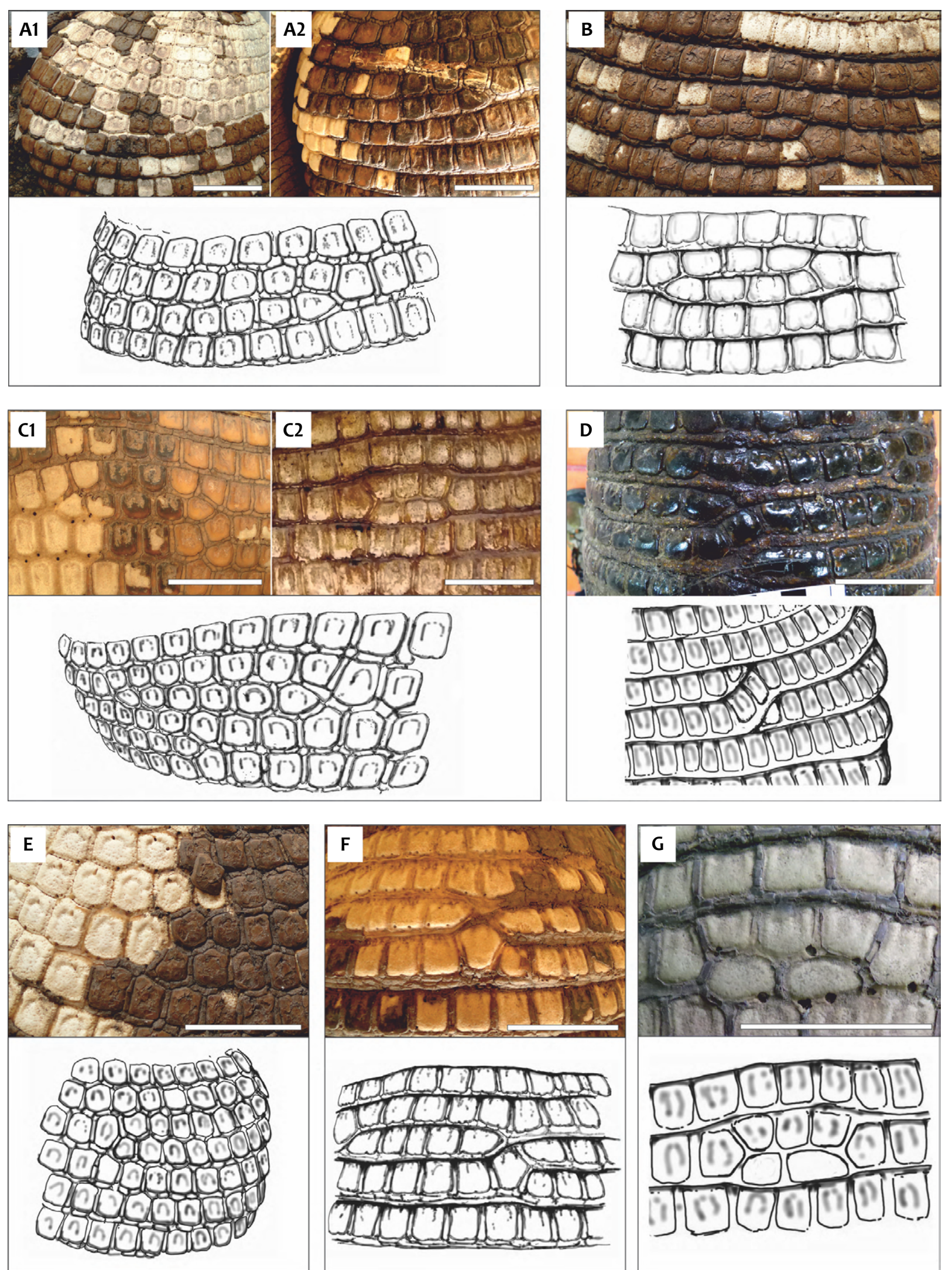

FIGURE 2. Structures identified together with schematic representations. A. Lateral wedging; A1. fixed osteoderms; A2. mobile osteoderms. B. Double lateral wedging. C. Isolated row; C1. fixed osteoderms; C2. mobile osteoderms. D. Crossed row. E. Confluent rows. F. Oversized osteoderm. G. Isolated osteoderms. Scale bars equivalent to $5 \mathrm{~cm}$. 


\section{Structures identified}

Lateral wedging. A row of osteoderms originates from one of the lateral borders of the carapace, and as it extends towards the dorsal area it is laterally wedged between the adjacent rows, becoming an incomplete row. The terminal osteoderm of the row can be identified as it develops a characteristic triangular or "wedged" shape. This wedging can occur at any point between the lateral border of the carapace where the row originates and the most dorsal area, but without reaching the opposite half of the carapace. This structure has been recorded for both the scapular and pelvic shield, and in the mobile bands (FIG. 2A).

Double lateral wedging. This structure is a special case of lateral wedging. Two consecutive rows of osteoderms originate from each lateral border of the carapace respectively, and as they extend towards the dorsal area they are wedged between each other and the adjacent rows, becoming incomplete rows. As it happens with the simple case of lateral wedging, the terminal osteoderms of the two wedged rows develop a triangular shape. However, unlike the simple case, this structure has only been recorded for the mobile bands, and not for the scapular and pelvic shields (FIG. 2B).

Isolated row. This structure consists of a row of osteoderms of variable extension that does not reach any of the lateral borders of the carapace. This happens as both endings of the row are laterally wedged between the adjacent rows. As in other wedged structures, terminal osteoderms from both sides of the row develop a triangular shape. The development of this incomplete row produces a deformation in the adjacent rows, with osteoderms reduced in size and displaced in order to adjust to the available space. This structure differs from the double lateral wedging in that it does not originate from any of the lateral margins of the carapace. It has been recorded for both the scapular and pelvic shields and for the mobile bands (FIG. 2C).

Crossed row. This very particular structure consists in a complete row of osteoderms that at some point is diagonally displaced until it occupies the position that would correspond to the immediately superior or inferior row. The osteoderms located at the transition point develop a normal morphology but in a diagonal position, generating the lateral wedging of the adjacent rows at the point where the displacement occurs. This structure has only been recorded for the mobile bands (FIG. 2D).

Confluent rows. This structure involves a total of three incomplete rows of osteoderms. Two consecutive rows extend from one lateral border of the carapace, while a third one extends from the opposite border until encountering the first two. At this point, the osteoderms of the consecutive rows are approximately half the size of those of the opposite row, and both terminal osteoderms of these bands are laterally limited with the terminal osteoderm of the opposite band. Unlike in lateral wedging, terminal osteoderms of the confluent rows maintain their original shape, but are modified in size. This structure has been recorded for both the scapular and pelvic shields (FIG. 2E).

Oversized osteoderm. A random osteoderm of a complete row is greatly oversized, extending either towards the anterior or posterior part of the carapace, and therefore occupying the space that would correspond to two adjacent rows. In turn, this generates the lateral wedging of the affected rows at both sides of the oversized osteoderm, giving place to two incomplete rows. This structure has been recorded for the scapular shield and the mobile bands (FIG. 2F).

Isolated osteoderms. This structure is composed of a variable number of isolated osteoderms that are surrounded by complete rows. This produces a deformation in the adjacent rows, with osteoderms reduced in size and displaced in order to adjust to the available space. Contrary to the isolated row structure, these osteoderms do not compose a defined row, as they develop aberrant morphologies and those on the extremes are not laterally wedged. This structure has only been recorded between the last mobile band and the first row of fixed osteoderms of the pelvic shield (FIG. 2G).

\section{DISCUSSION}

Both extant and extinct armadillos exhibit wide variability in the morphology of their dorsal carapace. Far beyond the evident differences between different species, intraspecific variability is also considerable. Each individual P. maximus that we examined presented a unique carapace pattern. Individual variation has been noted for other extant species such as Zaedyus pichiy (Desmarest, 1804) (see Superina \& Abba, 2014), but has not been analyzed in detail.

Among the structures we identified, some appear to be very common, while others may not be. The simple case of lateral wedging was the most common structure we observed; it was present in all our specimens. Other structures such as confluent rows or oversized osteoderms were common, present in more than half of the sample. In turn, we found isolated rows and isolated osteoderms in less than half of the sample. The rarest structures in our sample are the double lateral wedging, in two individuals, and the crossed row, in just one individual. 

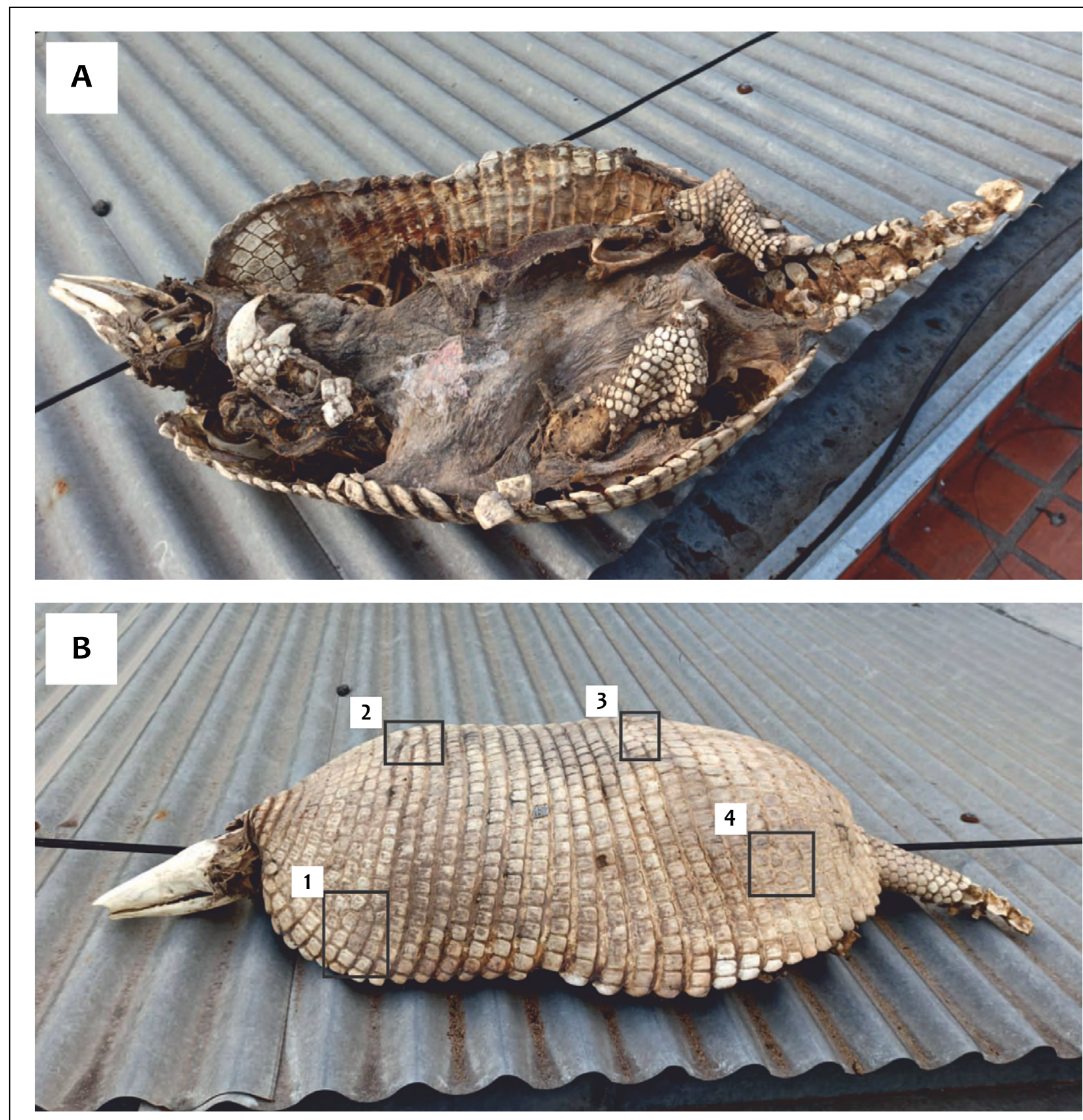

FIGURE 3. Structure identification in a desiccated specimen (LPV-CO-56). A. Ventral view. B. Dorsal view. 1. Lateral wedging in the scapular shield. 2. Confluent rows. 3. Isolated row. 4. Lateral wedging in the pelvic shield.

The precise location and number of times that these structures appear on each carapace is unique to each individual.

According to the principal osteoderm development studies carried out for extant armadillos, osteoderm ossification occurs during the embryonic stage, so the configuration pattern of the osteoderms that compose the dorsal carapace is already defined prior to parturition (Cooper, 1930; Vickaryous \& Hall, 2006). We assume therefore that the structures we identified are already present at birth and are preserved through the individual's entire lifespan.
The structure we describe can help to recognize specific individuals in field studies, particularly when the animals are captured. Recently, Massocato \& Desbiez (2019) published a series of guidelines to help in the identification of $P$. maximus individuals recorded by camera traps, including scale patterns, coloration patterns, and natural marks. Though the recognition of the proposed structures and their variations can be more challenging in camera trap photos because they provide only partial and sometimes distorted views of the animals, our structures can be a complementary method for camera trap studies. The main benefit of documenting these 
structures may reside in the potential recognition of particular individuals even a long time after death (FIG. 3), because the carapace can be preserved for a long time in natural environments even after the decomposition of the soft tissues and the disarticulation of the axial skeleton (Muñoz, 2015).

Priodontes maximus is globally classified as Vulnerable by the IUCN Red List, and the population overall is decreasing. In Argentina, its situation is even worse, and it is classified as Endangered (Di Blanco \& Superina, 2019). In this context, we strongly believe in the importance of implementing as many tools and monitoring strategies as possible, in order to maximize the effectiveness of conservation efforts.

\section{ACKNOWLEDGEMENTS}

We thank R. Pujol and F. Amione (Museo de Ciencias Naturales Augusto Schulz), M. Díaz (Colección Mamíferos, Facultad de Ciencias Naturales e Instituto Miguel Lillo) and R. Caputo (Museo Municipal de Ciencias Naturales "Carlos Darwin") for access to the studied specimens. M. Zaracho and S. Antúnez provided valuable photographs. A.E. Zurita made valuable observations and comments. We also thank the anonymous reviewers and the editors A.M. Abba and M. Superina, whose suggestions greatly improved the manuscript.

\section{REFERENCES}

Abba, A.M. \& M. Superina. 2010. The 2009/2010 armadillo Red List assessment. Edentata 11: 135-184. https://doi.org/10.5537/020.011.0203

Anacleto, T.C.S., F. Miranda, I. Medri, E. Cuellar, A.M. Abba \& M. Superina. 2014. Priodontes maximus. The IUCN Red List of Threatened Species 2014: e. T18144A47442343. https://dx.doi.org/10.2305/IUCN. UK.2014-1.RLTS.T18144A47442343.en. Accessed on 25 October 2020.

Barasoain, D., V.H. Contreras, R.L. Tomassini \& A.E. Zurita. 2020. A new pygmy armadillo (Cingulata, Euphractinae) from the late Miocene of Andean Argentina reveals an unexpected evolutionary history of the singular Prozaedyus lineage. Journal of South American Earth Sciences 100: 102589. https://doi. org/10.1016/j.jsames.2020.102589

Carter, T.S., M. Superina \& D.M. Leslie. 2016. Priodontes maximus (Cingulata: Chlamyphoridae). Mammalian Species 48: 21-34. https://oi.org/10.1093/mspecies/ sew002

Cooper, Z.K. 1930. A histological study of the integument of the armadillo, Tatusia novemcincta. American Journal of Anatomy 45: 1-37. https://doi.org/10.1002/ aja.1000450102

Desbiez, A.L.J., G.F. Massocato, D. Kluyber, C.N. Luba \& N. Attias. 2019. How giant are giant armadillos? The morphometry of giant armadillos (Priodontes maximus Kerr, 1792) in the Pantanal of Brazil. Mammalian Biology 95: 9-14. https://doi.org/10.1016/j. mambio.2018.12.007

Di Blanco, Y.E. \& M. Superina. 2019. Priodontes maximus. In: Categorización 2019 de los mamíferos de Argentina según su riesgo de extinción. Lista Roja de los mamíferos de Argentina. (SAyDS-SAREM, eds.). Digital version: <https://cma.sarem.org.ar/es/especienativa/priodontes-maximus $>$.

Eisenberg, J.F. \& K.H. Redford. 1999. Mammals of the Neotropics, Volume 3. The central Neotropics: Ecuador, Peru, Bolivia, Brazil. University of Chicago Press, Chicago. 609 pp.

Emmons, L.H. \& F. Feer. 1997. Neotropical rainforest mammals: a field guide. University of Chicago Press, Chicago. 307 pp.

Gaudin, T.J. \& H.G. McDonald. 2008. Morphologybased investigations of the phylogenetic relationships among extant and fossil xenarthrans. Pp. 24-36 in: The biology of the Xenarthra (S.F. Vizcaíno \& W. J. Loughry, eds.). University Press of Florida, Gainesville.

Krmpotic, C.M., A.A. Carlini \& G.J. Scillato-Yané. 2009. The species of Eutatus (Mammalia, Xenarthra): Assessment, morphology and climate. Quaternary International 210: 66-75. https://doi.org/10.1016/j. quaint.2009.06.031

Massocato, G.F. \& A.L.J. Desbiez. 2019. Guidelines to identify individual giant armadillos, Priodontes maximus (Kerr, 1792), through camera traps. Edentata 20: 1-16. https://doi.org/10.2305/IUCN.CH.2019. Edentata-20-1.2.en

Meritt, D. A. Jr. 2006. Research questions on the behavior and ecology of the giant armadillo (Priodontes maxi mus). Edentata 7: 30-33. https://doi.org/10.1896/ 1413-4411.7.1.30

Muñoz, A.S. 2015. Observaciones tafonómicas naturalistas sobre restos de armadillos (Dasypodidae) en Patagonia meridional. Archaeofauna 24: 239-251.

Noss, A.J., R. Peña \& D.I. Rumiz. 2004. Camera trapping Priodontes maximus in the dry forests of Santa Cruz, Bolivia. Endangered Species Update 2: 43-52.

Nowak, R.M. 1999. Walker's mammals of the world. The Johns Hopkins University Press, Baltimore and London. 2015 pp.

Redford, K.H. 1985. Food habits of armadillos (Xenarthra: Dasypodidae). Pp. 429-437 in: The evolution and ecology of armadillos, sloths, and vermilinguas (G.G. Montgomery, ed.). Smithsonian Institution Press, Washington and London.

Silveira, L., A. T. de Almeida Jácomo, M.M. Furtado, N.M. Torres, R. Sollmann \& C. Vynne. 2009. Ecology of the giant armadillo (Priodontes maximus) in the grasslands of central Brazil. Edentata 10: 25-34. https:// doi.org/10.1896/020.010.0112

Soibelzon, E., Á.R. Miño-Boilini, A.E. Zurita \& C.M. Krmpotic. 2010. Los Xenarthra (Mammalia) del Ensenadense (Pleistoceno inferior a medio) de la re- 
gión pampeana (Argentina). Revista Mexicana de Ciencias Geológicas 27: 449-469.

Superina, M. \& A.M. Abba. 2014. Zaedyus pichiy (Cingulata: Dasypodidae). Mammalian Species 46(905): 1-10. https://doi.org/10.1644/905.1

Superina, M. \& W.J. Loughry. 2012. Life on the half-shell: consequences of a carapace in the evolution of armadillos (Xenarthra: Cingulata). Journal of Mammalian Evolution 19: 217-224. https://doi.org/10.1007/ s10914-011-9166-x
Vickaryous, M.K. \& B.K. Hall. 2006. Osteoderm morphology and development in the nine-banded armadillo, Dasypus novemcinctus (Mammalia, Xenarthra, Cingulata). Journal of Morphology 267: 1273-1283. https://doi.org/10.1002/jmor.10475

Zurita, A.E., M. Taglioretti, M. De los Reyes, F. Cuadrelli \& D. Poire. 2016. Regarding the real diversity of Glyptodontidae (Mammalia, Xenarthra) in the late Pliocene (Chapadmalalan Age/Stage) of Argentina. Anais da Academia Brasileira de Ciências 88: 809-827. https://doi.org/10.1590/0001-3765201620 150113

Received: 13 November 2020; Accepted: 1 March 2021 


\title{
First estimates of potential lifespan of giant armadillo (Priodontes maximus) in the wild
}

\author{
Arnaud Leonard Jean Desbiez ${ }^{\mathrm{A}, \mathrm{B}, \mathrm{C}, 1}$, Duston Larsen $^{\mathrm{D}}$, Gabriel Favero \\ Massocato $^{\mathrm{A}, \mathrm{C}, \mathrm{E}}$, Nina Attias ${ }^{\mathrm{A}}$, Danilo Kluyber ${ }^{\mathrm{A}, \mathrm{C}, \mathrm{F}}$ \& Damián I. Rumiz ${ }^{\mathrm{C}}$ \\ A Instituto de Conservação de Animais Silvestres (ICAS), CEP 79040-290 Campo Grande, Mato Grosso do Sul, Brasil \\ ${ }^{\text {B }}$ Royal Zoological Society of Scotland (RZSS), Murrayfield, Edinburgh, EH12 6TS, United Kingdom \\ C Instituto de Pesquisas Ecológicas (IPÊ), Nazaré Paulista, CEP 12960-000, São Paulo, Brasil \\ ${ }^{D}$ San Miguelito Jaguar Conservation Ranch, Santa Cruz, Bolivia \\ ${ }^{E}$ Houston Zoo, 6200 Hermann Park Drive, Houston, TX 77030, USA \\ F Naples Zoo at Caribbean Gardens, Naples, FL 34102, USA \\ ${ }^{\mathrm{G}}$ Museo de Historia Natural Noel Kempff Mercado and Fundación Simón I. Patiño, Santa Cruz de la Sierra, Bolivia \\ 1Corresponding author. E-mail: adesbiez@hotmail.com
}

\begin{abstract}
This paper reports on results from two camera trapping initiatives where individual giant armadillos, Priodontes maximus, were identified and monitored over multiple years, thus providing insights into their potential lifespan. One camera trap array was located in the Brazilian Pantanal, in Mato Grosso do Sul, where an adult female was first identified in October 2011 and documented again in January 2021, leading us to estimate her age as at least 17.5 years old. The other camera trap array was located at the border of the Chaco alluvial plains in Santa Cruz, Bolivia, where a female was first registered in June 2004 and then again in January 2019; we estimate her age to be at least 18 years old. While recognizing that these two data points are insufficient to evaluate life expectancy of the species, this paper does provide the first evidence of potential lifespan of wild P. maximus. It also shows that both females were documented in the same area after intervals of 10 and 15 years, providing new clues on long-term site fidelity. This paper highlights the importance of long-term camera trap arrays for the study of cryptic nocturnal mammals that are long lived and occur at low densities.
\end{abstract}

Keywords: Bolivia, Brazil, camera traps, Cingulata, individual identification, maximum lifespan

Primeras estimaciones de longevidad potencial del armadillo gigante (Priodontes maximus) en la naturaleza

Resumen Este artículo informa sobre los resultados de dos iniciativas de fototrampeo en las que se identificaron y monitorearon individuos de armadillo gigante, Priodontes maximus, a lo largo de los años, y que proporcionan información sobre su longevidad potencial. Un conjunto de cámaras trampa se ubicó en el Pantanal brasileño, en Mato Grosso do Sul, donde una hembra adulta fue identificada por primera vez en octubre de 2011 y documentada nuevamente en enero de 2021, por lo que se estima que tiene al menos 17,5 años de edad. El otro conjunto de cámaras trampa se ubicó en el límite de las llanuras aluviales del Chaco en Santa Cruz, Bolivia, donde se registró una hembra por primera vez en junio de 2004 y luego nuevamente en enero de 2019, por lo que su edad se estimó en más de 18 años. Si bien reconocemos que estos dos datos son insuficientes para evaluar la esperanza de vida de la especie, este documento proporciona la primera evidencia de la longevidad potencial de $P$. maximus silvestres. También muestra que ambas hembras fueron documentadas en la misma área después de 10 o 15 años, proporcionando nuevas pistas sobre la fidelidad del sitio a largo plazo. Este artículo destaca la importancia del seguimiento con cámaras trampa a largo plazo para el estudio de mamíferos nocturnos crípticos que tienen una vida larga y se encuentran en densidades bajas.

Palabras clave: Bolivia, Brasil, Cingulata, identificación individual, longevidad máxima, trampas cámara 


\section{INTRODUCTION}

Longevity (life expectancy at birth), maximum lifespan, and reproductive lifespan are key parameters used to describe the population dynamics of wild animal populations (Radchuk et al., 2016; Lacy, 2019). Reproductive lifespan is also employed for estimation of a species generation length, which in turn is used for extinction risk assessment by the IUCN Red List (Fung \& Waples, 2017; IUCN, 2019). While well explored theoretically, these parameters have rarely been documented in wild animals and are often based on estimates (Pe'er et al., 2013; Morrison et al., 2016). Estimates are often guessed or based on animals living under human care, which may artificially inflate the estimates (Pe'er et al., 2013; Lacy, 2019). Long-term studies in the wild are necessary to increase the accuracy of these parameter estimates, especially for species that do not possess morphological and anatomical features that allow age estimation. However, these longterm studies are overall rare and usually focus on animals that can be relatively easily observed (e.g., Breuer et al., 2009).

The giant armadillo Priodontes maximus Kerr, 1792 (Mammalia: Cingulata) is the largest living species of Cingulata, with adults measuring up to $1.5 \mathrm{~m}$ and weighing up to $60 \mathrm{~kg}$ (Carter et al., 2016; Desbiez et al., 2019). This cryptic species is naturally rare, but widely distributed throughout 11 countries in South America, where it occupies habitats ranging from tropical forest to open savanna (Abba \& Superina, 2010). Giant armadillos are myrmecophagous, have extensive home ranges, are solitary, nocturnal, and fossorial, spending all day in their deep burrows (Eisenberg \& Redford, 1999; Silveira et al., 2009; Desbiez \& Kluyber, 2013; Desbiez et al., 2020a; Desbiez et al., 2021). Furthermore, this species is notoriously difficult to capture and study in the wild (Silveira et al., 2009; Carter et al., 2016; Quiroga et al., 2017; Desbiez et al., 2020a). Currently, there are no estimates of maximum lifespan for P. maximus, although it is reported that one captive individual lived 16 years (Carter et al., 2016).

Camera trapping is one of the main tools used to advance P. maximus research (Noss et al., 2004; Porfirio et al., 2012; Desbiez \& Kluyber, 2013; Aya-Cuero et al., 2017; Quiroga et al., 2017; Massocato \& Desbiez, 2017; Esteves et al., 2018; Desbiez et al., 2020b,c; Di Blanco et al., 2020; Fontes et al., 2020). Records obtained by camera traps can allow the individual identification of $P$. maximus if properly examined (Noss et al., 2004; Massocato \& Desbiez, 2019). This paper reports on results from two camera trapping initiatives where giant armadillos were individually identified and monitored over multiple years, providing insights into the potential lifespan of P. maximus.

\section{MATERIALS AND Methods}

Fazenda Baia das Pedras, Brazil. A long-term study on $P$. maximus is being carried out since July 2010 on private cattle ranches $\left(19^{\circ} 16^{\prime} \mathrm{S}, 55^{\circ} 42^{\prime} \mathrm{W}\right)$ in the Brazilian Pantanal (Nhecolândia subregion; Desbiez et al., 2020a) of Mato Grosso do Sul. The study includes the use of both camera trapping and animal capture for the placement of telemetry monitoring devices (see Desbiez et al., 2020c). Camera traps have been installed following two different approaches (Desbiez et al., 2020a,c): (1) Cameras were placed in front of active giant armadillo burrows. This allowed us to detect not only the individuals that built and used the burrows but also passing individuals that often inspected scent marks left in the burrow entrance. (2) Two camera trap arrays were installed in areas known to be used by several telemetry-monitored individuals. From July 2016 to January 2017, we established one array $(\mathrm{n}=75$ camera sites) in an area where a cluster of 12 known individual $P$. maximus had been captured and monitored since the beginning of the project (2010). In 2020, a second array of 10 cameras was placed in the home range of one of the first giant armadillos monitored by the project (TC-04), following the methods used to install the previous array, as described in Desbiez et al. (2020c).

San Miguelito Jaguar Conservation Ranch, Bolivia. This cattle ranch (and tourist lodge) lies at the border of the Chaco alluvial plains and the Precambrian shield, in the lowlands of Santa Cruz. Its owner has hosted wildlife studies since the 1990s at a research camp by the San Julián river $\left(17^{\circ} 05^{\prime} \mathrm{S}\right.$, $\left.61^{\circ} 47^{\prime} \mathrm{W}\right)$, which is surrounded by wetlands, palm savannas, and dry forests (see habitat and fauna description in Rumiz et al., 2002; Rivero et al., 2005). In order to study jaguars and other terrestrial mammals, two 60-day intensive camera trap surveys were conducted around this camp in 2002 and 2004. In addition, a non-systematic monitoring effort has been conducted with a few cameras since 2017 to date. The survey in 2002 (20 September to 20 November; Noss et al., 2004) had 22 camera sites with paired cameras covering a polygon of $24 \mathrm{~km}^{2}$, and produced three records of two female giant armadillos. The survey in 2004 ( 5 June to 8 August; Arispe et al., 2005) had 25 camera sites spread over $54 \mathrm{~km}^{2}$, and resulted in 11 records of three females and two males. The recent records, from 2018 and 2019, allowed us to identify two P. maximus individuals.

\section{Individual identification}

Individual $P$. maximus were identified using morphological characteristics following Massocato \& Desbiez (2019) and Noss et al. (2004). Characteristics included: (1) cephalic scale pattern (the pattern of scales displayed on the animal's head is unique and varies in shape, number, and 
arrangement); (2) tail markings (individuals may have dark scales along the tail interspersed among the lighter scales); (3) flank scale pattern (the number of light scales between the edge of the carapace and the dark scales, as well as indentations and shapes formed by the light and dark scales are often used to identify individuals); (4) lighter scales above the base of the tail (the width and shape of the light band between the base of the tail and the darker scales at the upper part of the carapace varies between individuals); and (5) scale coloration on the hind limbs (some individuals have a dark ankle brace on the upper hind limb that may be of varying shape or size on each side or even absent in some individuals). Natural marks, such as scars, also were used.

\section{RESULTS}

\section{Fazenda Baia das Pedras, Brazil}

TC-04 is an adult female, first captured in October 2011 and later recorded by camera traps in August 2016 and January 2021 (FIG. 1). In 2011, during its first capture examination, TC-04 showed signs of having previously bred, due to her elongated vulva that measured about $7 \mathrm{~cm}$ and teats over $2.5 \mathrm{~cm}$ (Desbiez et al., 2019; Massocato \& Desbiez, 2019). A recent genetic study that is part of our research program showed that another individual (TC-10) captured in an area near hers was her offspring (N.T. Rodrigues, unpublished data). TC-10 was estimated to be between 2.5 and 3.5 years old when captured in June 2013, based on his body
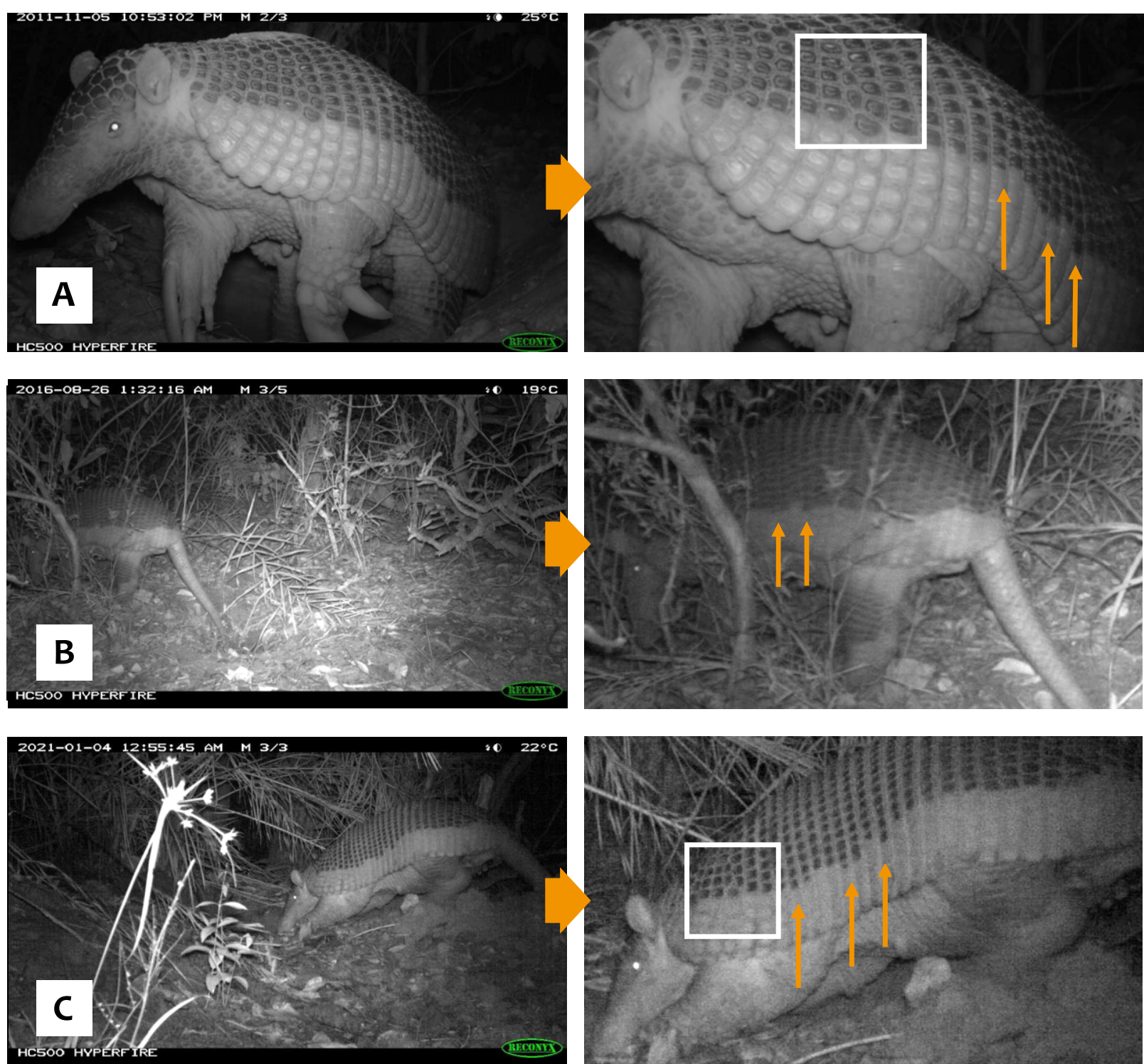

FIGURE 1. Identification of the individual giant armadillo (Priodontes maximus; TC-04) on three occasions at Baia das Pedras ranch, Brazil. On the left are the original camera trap images with the recorded date, and on the right the photos are augmented with arrows and highlighted areas that point to the unique patterns of white and dark scales used for individual identification. A. Photo taken in November, 2011. B. Photo in August, 2016. C. Photo in January, 2021. 
mass and penis size (following Luba et al., 2020). The age estimates for TC-10 are also based on interbreeding interval and length of parental care estimates for the species (Desbiez et al., 2020b). When first captured, TC-04 was intensively monitored with camera traps that were placed in front of all the burrows she was known to use. Nevertheless, TC-10 was never caught in these traps. Hence, we can conclude that TC-04 had given birth to TC-10 more than 18 months before, as cubs are weaned between 11 and 12 months of age and only use their mother's burrows until they are approximately 1.5 years old (Desbiez et al., 2020b). Therefore, the intense parental care period was likely over when we first caught TC-04, because otherwise we would have recorded TC-10 using TC-04's burrows (Desbiez et al., 2020b). Furthermore, P. maximus gestation is five months long (Desbiez et al., 2020b), and individuals are estimated to reach sexual maturity between 6.5 to 8 years of age (Luba et al., 2020). Hence, TC-04 was at least 8.5 to 10 years old when first captured, assuming she reproduced right after achieving sexual maturity and that TC-10 resulted from her first breeding event. If not, then it is possible TC-04 could be even older. TC-04 was recorded alive by our first camera trap array in 2016 (Desbiez et al., 2020c), and recaptured in our new array in January 2021. Based on the foregoing, this latter record leads us to conclude that she is at least 17.5 years old.

\section{San Miguelito Jaguar Conservation Ranch, Bolivia}

The female F1 was first identified on 21 June 2004 and last identified in January 2019 (FIG. 2). It is challenging to gauge the age of F1 when she was first documented in the camera trap because small adults and large subadults can present similar body mass and size (Desbiez et al., 2019). Female adults and sub-adults can be distinguished by the size of teats or vulva (Desbiez et al., 2019) and, while it is generally possible to make these distinctions from camera trap records (Massocato \& Desbiez, 2019), it was not possible to do so for the 2004 record of F1. Therefore, while the image presents an animal with a body resembling that of an adult, this female could have been as young as 3 or 4 years old. However, because this female was registered in the same location after 15 years, we can assume that in 2004 she was already a resident individual. In the Pantanal, the Giant Armadillo Conservation Program has registered two young subadult females (TC-21 and TC-22) that dispersed from their natal areas when they were estimated to be between 4 to 6 years of age. Therefore, a conservative guess for the age of $F 1$ would be that she was at least 4 years old when first recorded in 2004. This would mean that in 2019 she was at least 18 years old.

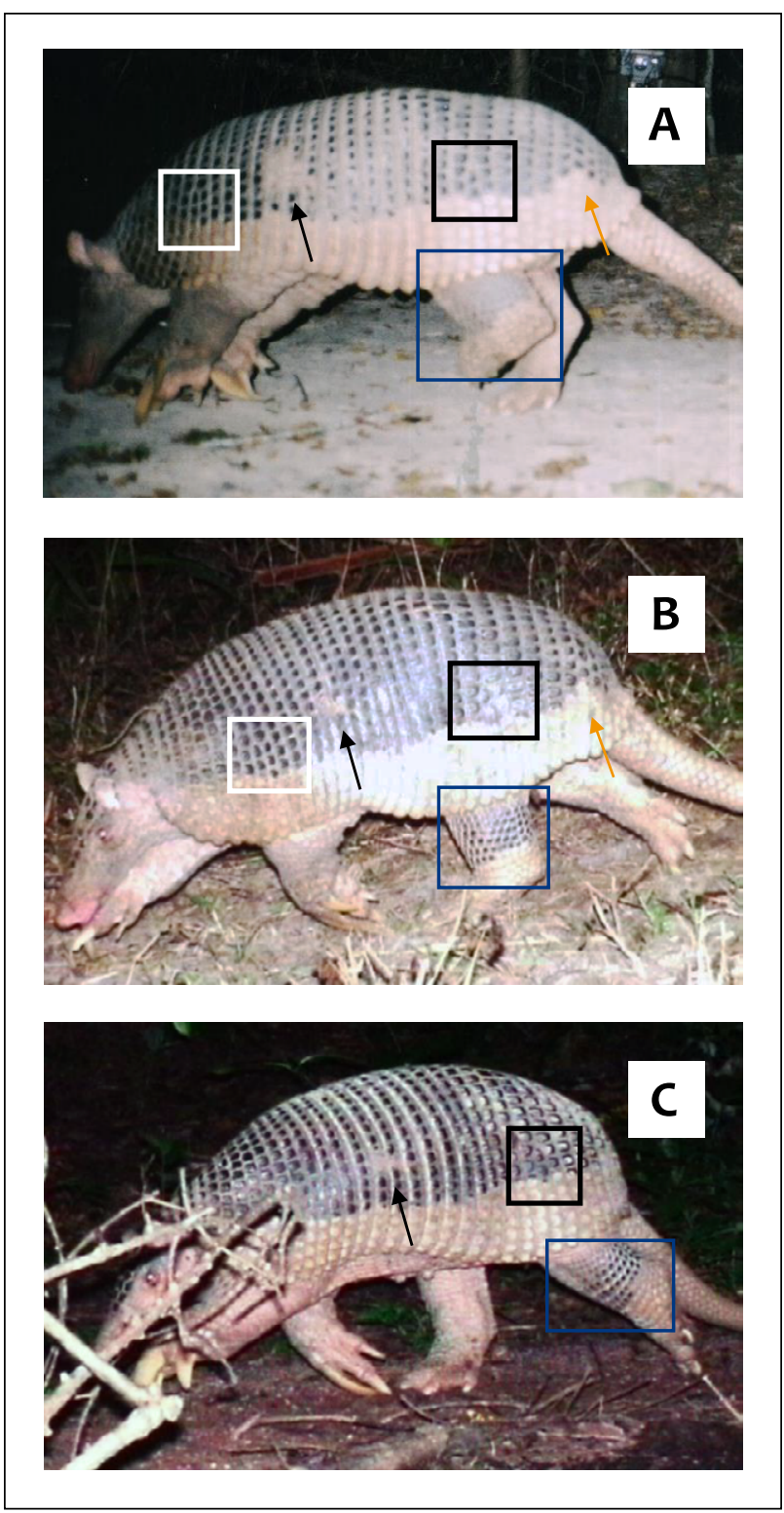

FIGURE 2. Identification of the individual giant armadillo (Priodontes maximus; F1) on three occasions at San Miguelito Jaguar Conservation Ranch, Bolivia. A. Photo in June, 2004. B. Photo in August, 2018. C. Photo in January, 2019. The arrows and highlighted areas point to the characters used for individual identification, which include areas where the armor is discolored, as well as unique patterns of white and dark scales on the armor and hind leg.

\section{DISCUSSION}

Here, we provide the first long-term records of range-resident wild giant armadillos, thus allowing us to estimate their potential lifespan.

To age giant armadillos and gather data on potential lifespan, we must rely on capture/recapture and individual markings. Since 2010, the Giant Armadillo Conservation Program has captured a total of 34 individual giant armadillos and has shown that it is possible to distinguish subadults and adults through morphometric measures (Desbiez 
et al., 2019), as well as by inspecting their genitals (Massocato \& Desbiez, 2019; Luba et al., 2020). However, once animals have reached full adult size and sexual maturity, it is impossible to guess their age based on these morphological characters. During our research, we have re-captured adult animals and, depending on the season, the same animal can present slight physical differences. For example, weight may vary by one to three $\mathrm{kg}$ at different times of the year (Desbiez et al., 2019). In addition, the appearance and impressions of wear on the carapace scales, and even claws, can be different among captures (A. Desbiez, pers. obs.).

Age of mammals is often evaluated through morphological indices such as growth annuli, secondary physical characteristics related to age, and growth models (Eaton \& Link, 2011). Luba et al. (2019) used body mass and penis size to estimate the age of male $P$. maximus until they reached full body size and sexual maturity. Nevertheless, to age adult individuals we currently must rely on recapture events and individual markings. When first captured, we believe TC-04 was at least 8.5 years old, but she could have been 20 years old, based on the tools for age estimation we have today. The same rationale can be applied to $\mathrm{F} 1$. Therefore, our age estimates for TC-04 and F1 are both conservative, but show that giant armadillos can live nearly 20 years in the wild, and likely beyond that.

We recognize that evaluating life expectancy, maximum lifespan or reproductive lifespan requires much more data than these two examples. Mayne et al. (2020) highlight how using point values may inflate estimates due to outliers or, on the contrary, not determine the appropriate age due to undersampling. These authors suggest estimating life expectancy from a population's full dataset, or life table, rather than a point value from a single longlived individual to avoid such problems. However, this implies that a methodology of ageing exists for a particular species, either through individual markings or morphological indices that allow building a life table (Eaton \& Link, 2011), or it requires access to long-term population data, neither of which are currently available for P. maximus.

There are a number of reasons to suspect a long lifespan for P. maximus. First, recent publications on giant armadillos highlight the low population growth rate of the species, with sexual maturity occurring around 6.5 to 8 years of age (Luba et al., 2020), and long parental care; the only documented interbirth interval is three years (Desbiez et al., $2020 \mathrm{~b})$. These traits are usually associated with K-selected species that are typically long-lived (Pianka, 1970). While the $\mathrm{r} / \mathrm{K}$ selection paradigm has been displaced by demographic models, these general traits still hold true. Second, age at maturity also is usually proportional to adult lifespan (Magalhães et al., 2007), and giant armadillos reach sexual maturity late compared to other species of armadillo (Luba et al., 2020). Third, larger animals live longer (Speakman, 2005). Finally, in captivity, species of Xenarthra generally live longer, with records of armadillos (Cingulata) reaching 28 years, anteaters (Pilosa, Vermilingua) 30 years, and sloths (Pilosa, Folivora) 40 years (ZIMS, 2021). For all these reasons, we therefore predict the $P$. maximus lifespan to be $\geq 20$ years.

Another important piece of data revealed by our camera trap images is that both $P$. maximus females were recorded using the same area many years after being first documented. Desbiez et al. (2020a) reported on the spatial ecology of 23 P. maximus and argued that movement patterns of both sexes were indicative of site fidelity. Hence, although we cannot ensure that these individuals remained in these areas during all the years they were not monitored/ detected, the results from this study reinforce the suggestion of long-term site fidelity made by Desbiez et al. (2020a).

While we recognize the limitations of the data presented, these results are unique and important for wild P. maximus. We intend to continue the longterm monitoring of $P$. maximus at Baia das Pedras and the San Miguelito Jaguar Conservation Ranch, and hope to be able to report on TC-04 and F1 over the next five years. Most importantly, we hope to be able to document if they are still breeding. The findings of our study reinforce the view that long-term camera trap studies are essential tools for the study of cryptic nocturnal mammals that are long-lived and occur at low densities. These studies can provide crucial insights into certain life history parameters, so long as individual identification is possible.

\section{ACKNOWLEDGEMENTS}

We are grateful to the owners of the Fazenda Baía das Pedras for their hospitality, generous support, and permission to work on their land. This study is part of the Giant Armadillo Conservation Program, which benefited from multiple grants, mostly from zoos in North America and Europe, listed at https://www.giantarmadillo.org/partners. We want to thank the late Ronald Larsen for encouraging wildlife studies at San Miguelito ranch and the former Wildlife Conservation Society/Museo NKM team (A. Noss, R. Arispe, C. Venegas, S. Angulo, K. Rivero) for sharing the original camera trap pictures for comparison with the most recent surveys. This study was authorized by the Bolivian biodiversity authority in the framework of the jaguar conservation research project by Museo NKM. We are grateful to William J. Loughry and two anonymous reviewers for improving the quality of this manuscript. 


\section{REFERENCES}

Abba, A.M. \& M. Superina. 2010. The 2009/2010 armadillo Red List assessment. Edentata 11: 135-184. https://doi.org/10.5537/020.011.0203

Arispe, R., D. Rumiz \& C. Venegas. 2005. Second camera-trap survey for jaguars (Panthera onca) and other mammals at San Miguelito Ranch. June - August/2004. WCS - Museo NKM Report. Santa Cruz, Bolivia. 22 pp.

Aya-Cuero, C., A. Rodríguez-Bolaños \& M. Superina. 2017. Population density, activity patterns, and ecological importance of giant armadillos (Priodontes maximus) in Colombia. Journal of Mammalogy 98: 770-778. https://doi.org/10.1093/jmammal/gyx006

Breuer, T., M. B. N. Hockemba, C. Olejniczak, R.J. Parnell \& E.J. Stokes. 2009. Physical maturation, life-history classes and age estimates of free-ranging Western Gorillas-insights from Mbeli Bai, Republic of Congo. American Journal of Primatology 71: 106-119. https://doi.org/10.1002/ajp.20628

Carter, T.S., M. Superina \& D. M. Leslie. 2016. Priodontes maximus (Cingulata: Chlamyphoridae). Mammalian Species 48: 21-34. https://doi.org/10.1093/mspecies/ sew002

Desbiez, A.L.J. \& D. Kluyber. 2013. The role of giant armadillos (Priodontes maximus) as physical ecosystem engineers. Biotropica 45: 537-540. https://doi. org/10.1111/btp.12052

Desbiez, A.L.J., G.F. Massocato, D. Kluyber, C.N. Luba \& N. Attias. 2019. How giant are giant armadillos? The morphometry of giant armadillos (Priodontes maximus Kerr, 1792) in the Pantanal of Brazil. Mammalian Biology 95: 9-14. https://doi.org/10.1016/j. mambio.2018.12.007

Desbiez, A.L.J., G.F. Massocato, D. Kluyber, L.G.R. Oliveira-Santos \& N. Attias. 2020a. Spatial ecology of the giant armadillo (Priodontes maximus) in Midwestern Brazil. Journal of Mammalogy 101: 151-163. https://doi.org/10.1093/jmammal/gyz172

Desbiez, A.L.J., G.F. Massocato \& D. Kluyber. 2020b. Insights into giant armadillo (Priodontes maximus Kerr, 1792) reproduction. Mammalia 84: 283-293. https:// doi.org/10.1515/mammalia-2019-0018

Desbiez, A.L.J., G.F. Massocato, N. Attias \& M. Cove. 2020c. Comparing density estimates from a short-term camera trap survey with a long-term telemetry study of giant armadillos (Priodontes maximus). Mastozoología Neotropical 27: 1-18. https://doi.org/10.31687/ saremMN.20.27.2.0.08

Desbiez, A.L.J., D. Kluyber, G.F. Massocato \& N. Attias. 2021. Methods for the characterization of activity patterns of elusive species: the giant armadillo in the Brazilian Pantanal. Journal of Zoology 315: 301-312. https://doi.org/10.1111/jzo.12921

Di Blanco, Y.E., A.L.J. Desbiez, D. di Francescantonio \& M.S. Di Bitetti. 2020. Excavations of giant armadillos alter environmental conditions and provide new re- sources for a range of animals in their southernmost range. Journal of Zoology 311: 227-238. https://doi. org/10.1111/jzo.12782

Eaton, M.J. \& W.A. Link. 2011. Estimating age from recapture data: integrating incremental growth measures with ancillary data to infer age-at-length. Ecological Applications 21: 2487-2497. https://doi. org/10.1890/10-0626.1

Eisenberg, J.F. \& K.H. Redford. 1999. Mammals of the Neotropics, Volume 3. The central Neotropics: Ecuador, Peru, Bolivia, Brazil. The University of Chicago Press, Chicago. 624 pp.

Esteves, C.F., D.H. Homem, R. Bernardo \& E.F. Lima. 2018. Notes on giant armadillo Priodontes maximus (Cingulata: Chlamyphoridae) distribution and ecology in Eucalyptus plantation landscapes in eastern Mato Grosso do Sul State, Brazil. Edentata 19: 47-56. https://doi.org/10.2305/IUCN.CH.2018.Edentata19-1.6.en

Fontes, B.L. et al. 2020. The local extinction of one of the greatest terrestrial ecosystem engineers, the giant armadillo (Priodontes maximus) in one of its last refuges in the Atlantic Forest will be felt by a large vertebrate community. Global Ecology and Conservation 24: e01357. https://doi.org/10.1016/j.gecco.2020.e01357

Fung, H.C. \& R.S. Waples. 2017. Performance of IUCN proxies for generation length. Conservation Biology 31: 883-893. https://doi.org/10.1111/cobi.12901

IUCN Standards and Petitions Committee. 2019. Guidelines for using the IUCN Red List categories and criteria. Version 14. Prepared by the Standards and Petitions Committee. http://www.iucnredlist.org/ documents/RedListGuidelines.pdf. Accessed on 30 March 2021.

Lacy, R.C. 2019. Lessons from 30 years of population viability analysis of wild populations. Zoo Biology 38: 67-77. https://doi.org/10.1002/zoo.21468

Luba, C.N., et al. 2020. Size matters: penis size, sexual maturity and their consequences for giant armadillo conservation planning. Mammalian Biology 100: 621630. https://doi.org/10.1007/s42991-020-00065-3

Magalhães, J.P., J. Costa \& G. M. Church. 2007. An analysis of the relationship between metabolism, developmental schedules, and longevity using phylogenetic independent contrasts. The Journals of Gerontology: Series A 62: 149-160. https://doi.org/10.1093/ gerona/62.2.149

Massocato, G.F. \& A.L.J. Desbiez. 2017. Presença e importância do tatu-canastra, Priodontes maximus (Kerr, 1792), na maior área protegida do leste do Estado de Mato Grosso do Sul, Brasil. Edentata 18: 26-33. https:// doi.org/10.2305/IUCN.CH.2017.Edentata-18-1.4.en

Massocato, G.F. \& A.L.J. Desbiez. 2019. Guidelines to identify individual giant armadillos, Priodontes maximus (Kerr, 1792), through camera traps. Edentata 20: 1-16. https://doi.org/10.2305/IUCN.CH.2019. Edentata-20-1.2.en 
Mayne, B., O. Berry \& S. Jarman. 2020. Redefining life expectancy and maximum lifespan for wildlife management. Austral Ecology 45: 855-857. https://doi. org/10.1111/aec.12931

Morrison, C., C. Wardle \& J. G. Castley. 2016. Repeatability and reproducibility of population viability analysis (PVA) and the implications for threatened species management. Frontiers in Ecology and Evolution 4: 98. https://doi.org/10.3389/fevo.2016.00098

Noss, A.J., R. Peña \& D.I. Rumiz. 2004. Camera trapping Priodontes maximus in the dry forests of Santa Cruz, Bolivia. Endangered Species Update 21: 43-52.

Pe'er, G. et al. 2013. A protocol for better design, application and communication of population viability analyses. Conservation Biology 27: 644-656. https://doi. org/10.1111/cobi.12076

Pianka, E.R. 1970. On r and K selection. The American Naturalist 104: 592-597. https://doi.org/10.1086/282697

Porfírio, G. O. et al. 2012. New records of giant armadillo Priodontes maximus (Cingulata: Dasypodidae) at Serra do Amolar, Pantanal of Brazil. Edentata 13: 72-75. https://doi.org/10.5537/020.013.0110

Quiroga, V.A., Y.E. Di Blanco, A. Noss, A.J. Paviolo \& M.S. Di Bitetti. 2017. The giant armadillo (Priodontes maximus) in the Argentine Chaco. Mastozoología Neotropical 24: 163-175.

Radchuk, V., S. Oppel, J. Groeneveld, V. Grimm \& N. Schtickzelle. 2016. Simple or complex: relative im- pact of data availability and model purpose on the choice of model types for population viability analyses. Ecological Modelling 323: 87-95. https://doi. org/10.1016/j.ecolmodel.2015.11.022

Rivero, K., D.I. Rumiz \& A.B. Taber. 2005. Differential habitat use by two sympatric brocket deer species (Mazama americana and M. gouazoubira) in a seasonal Chiquitano forest of Bolivia. Mammalia 69: 169-183. https://doi.org/10.1515/mamm.2005.015

Rumiz, D.I. et al. 2002. La biodiversidad de la Estancia San Miguelito, Santa Cruz, Bolivia: una justificación para establecer reservas privadas de conservación. Ecología en Bolivia, Documentos, Serie Biodiversidad 1: 1-68.

Speakman, J.R. 2005. Body size, energy metabolism and lifespan. Journal of Experimental Biology 208: 1717-1730. https://doi.org/10.1242/jeb.01556

Silveira, L., A.T.A. Jácomo, M.M. Furtado, N.M. Torres, R. Sollmann \& C. Vynne. 2009. Ecology of the giant armadillo (Priodontes maximus) in the grasslands of Central Brazil. Edentata 8-10: 25-34. https://doi. org/10.1896/020.010.0112

ZIMS - Zoological Information Management System. 2021. Species360 Zoological Information Management System. https://zims.species360.org. Accessed on 31 March 2021.

Received: 19 April 2021; Accepted: 20 May 2021 


\title{
Distribution, ecology, and conservation of Xenarthra in Bolivia - update to 2021
}

\author{
Enzo Aliaga-Rossel ${ }^{\mathrm{A}, \mathrm{B}, 1}$, Carmen Julia Quiroga ${ }^{\mathrm{C}, \mathrm{D}}$, Ximena Velez-Liendo ${ }^{\mathrm{E}, \mathrm{F}}$, \\ Alfredo Romero-Muñoz ${ }^{\mathrm{G}}$, Zulia Porcel ${ }^{\mathrm{H}}$, Robert Benedict Wallace ${ }^{\mathrm{H}}$, \\ Guido Marcos Ayala ${ }^{\mathrm{H}}$, María Estela Viscarra ${ }^{\mathrm{H}}$, Erika Cuéllar Soto ${ }^{\mathrm{I}}$, \\ TERESA TARIFA \& ANDREW NOSS ${ }^{\mathrm{K}, 1}$
}

\footnotetext{
A Instituto de Ecología, Universidad Mayor de San Andrés, Cota Cota Calle 27, Campus Universitario, La Paz, Bolivia

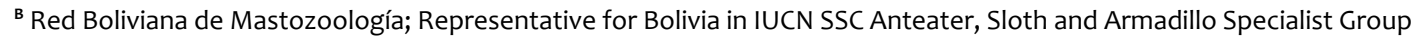

'Museo de Historia Natural «Alcide d'Orbigny», Av. Potosí 1458, Cochabamba, Bolivia

D University of South-Eastern Norway, Gullbringvegen 36, Bo i Telemark, 3800 Norway

E WildCRU, The Recanati-Kaplan Centre, Tubney House, Oxford OX13 5QL, United Kingdom

F Chester Zoo, Cedar House, Upton Chester $\mathrm{CH}_{2}$ 1LH, United Kingdom

${ }^{\complement}$ Geography Department, Humboldt-University Berlin, 10099 Berlin, Germany

${ }^{H}$ Wildlife Conservation Society (WCS) Bolivia, \#340 Gabino Villanueva, Calacoto, La Paz, Bolivia

' Department of Biology, Sultan Qaboos University, Muscat, Oman

J O. J. Smith Museum of Natural History, The College of Idaho, 2112 Cleveland Blvd., Caldwell, ID 83605, United States

${ }^{\mathrm{K}}$ Department of Geography and Center for Latin American Studies, 470 Grinter Hall, PO Box 115560, University of Florida, Gainesville, FL 32611-5560, United States

1 Corresponding authors.

E-mail: ealiagar@hotmail.com (EAR); anoss@ufl.edu (AN)
}

\begin{abstract}
We present an update on the taxonomy, distribution, ecology, threats, and conservation status of Bolivian Xenarthra (orders Cingulata and Pilosa) based on articles published between 2010 and 2021. The Andean hairy armadillo Chaetophractus nationi has been synonymized with the less threatened C. vellerosus. Cabassous squamicaudis has been revalidated for Bolivia. Dasypus kappleri has been divided into three species; D. beniensis is the species present in Bolivia. Cyclopes didactylus was divided into seven species; C. catellus is the species in Bolivia. Chlamyphorus was divided into two genera; Calyptophractus retusus is the species in Bolivia. Recent camera trap and biodiversity surveys extend records of Xenarthra into the dry forests of the central and southern Andes of Bolivia. No comprehensive population assessment or basic ecological studies were undertaken for any Xenarthra species in the country during the period. However, indirectly, armadillos and anteaters have been included in recent studies using camera traps to evaluate effects of forest management, forest fragmentation, agriculture, and hunting on terrestrial mammals. Deforestation is the major threat to Xenarthra, exacerbated by economic pressures, policy changes, and frequent extensive fires in the past decade. The majority of xenarthrans are affected by hunting for subsistence consumption, meat sales, and/or cultural purposes. Overall, the conservation status of Xenarthra species in Bolivia is thought to be relatively stable, with vast protected areas, indigenous territories, and certified forestry concessions where deforestation and hunting are limited. However, outside of protected areas, threats are increasing. Direct research on Bolivian Xenarthra is needed, especially studies on longterm population trends, habitat preferences, and distribution in less-studied and threatened ecosystems such as the Chiquitano Dry Forest and the Bolivian-Tucumán Forest.
\end{abstract}

Keywords: Anteaters, armadillos, sloths, taxonomy, threats 
Resumen Presentamos una actualización sobre la taxonomía, distribución, ecología, amenazas y estado de conservación de los Xenarthra (órdenes Cingulata and Pilosa) en Bolivia, con base en publicaciones entre 2010 y 2021. El armadillo peludo andino (quirquincho) Chaetophractus nationi ha sido sinonimizado con la especie menos amenazada C. vellerosus. Cabassous squamicaudis ha sido revalidado para Bolivia. Dasypus kappleri fue dividido en tres especies; D. beniensis es la especie en Bolivia. Cyclopes didactylus fue dividido en siete especies; C. catellus es la especie en Bolivia. Chlamyphorus fue dividido en dos géneros; Calyptophractus retusus es la especie en Bolivia. Estudios recientes con cámaras trampa y evaluaciones de biodiversidad han extendido la distribución de los Xenarthra a los bosques secos de los Andes centrales y meridionales de Bolivia. No existen evaluaciones poblacionales o estudios ecológicos para ninguna especie de Xenarthra. Indirectamente, los armadillos y osos hormigueros han sido incluidos en recientes estudios con cámaras trampa que evaluaron los efectos del manejo forestal, la fragmentación forestal, la agricultura y la caza de los mamíferos terrestres. La deforestación es la mayor amenaza para las especies de Xenarthra, agravada por la presión económica, los cambios de políticas y los extensos y frecuentes incendios de la última década. La mayoría de las especies están afectadas por la cacería de subsistencia, venta de carne y/o fines culturales. En general, se piensa que el estado de conservación de los Xenarthra en Bolivia es relativamente estable, debido a las vastas áreas protegidas, territorios indígenas y concesiones forestales certificadas donde la deforestación y la caza son aún limitadas. Fuera de las áreas protegidas las amenazas aumentan. Se requiere investigación dirigida hacia los Xenarthra, especialmente evaluaciones de sus tendencias poblacionales, preferencia de hábitat y distribución en ecosistemas menos estudiados y amenazados como los bosques de la Chiquitania y el bosque Boliviano-Tucumano.

Palabras clave: Amenazas, armadillos, osos hormigueros, perezosos, taxonomía

\section{INTRODUCTION}

In Bolivia, the supraorder Xenarthra is one of the least-studied mammal groups. This group consists of two orders, Pilosa and Cingulata, with 16 species recognized in Bolivia: eleven armadillos, two sloths, and three anteaters (Aguirre et al., 2019; Feijó \& Anacleto, 2021; TABLE 1). Noss et al. (2010a, $2010 b)$ published an exhaustive review of the distribution, ecology, and conservation of xenarthrans. Here, we present an update of the research on Xenarthra in Bolivia with focus on their taxonomy, distribution, ecology, threats, and conservation status. We evaluated references published between 2010 and 2021 using the bibliography for armadillos (between 2011 and 2019) on the IUCN SSC Anteater, Sloth \& Armadillo Specialist Group website https://www.xenarthrans.org/armadillo-bibliography/ and all other publications on Bolivian Xenarthra known to the authors.

\section{TAXONOMY}

Although the taxonomy of Cingulata and Pilosa has been stable above the family level, recent analyses using molecular techniques have reorganized the taxonomy of several genera of Bolivian armadillos (Aguirre et al., 2019). The most notable change is the synonymization of the Andean hairy armadillo Chaetophractus nationi (locally called a quirquincho) with the more common screaming hairy armadillo, Chaetophractus vellerosus, based on morphological and molecular analyses of animals from Oruro Department (Abba et al., 2015). Further molecular analyses suggested that C. nationi is a disjunct series of populations of C. vellerosus (Poljak et al., 2018). However, we question the synonymization of $C$. nationi because quirquinchos live exclusively in sand dunes at 4,000 m asl, whereas C. vellerosus are habitat generalists living at lower altitudes, and the two distributions are disjunct.

Analyses for the genus Dasypus by Feijó \& Cordeiro-Estrela (2016) and Feijó et al. (2018, 2019) suggested that the greater long-nosed armadillo D. kappleri was a complex of three species with allopatric distributions, with the Beni greater longnosed armadillo $D$. beniensis being the species that occurs in Bolivia. The genus Cabassous was reviewed by Feijó \& Anacleto (2021), and based on complementary morphological approaches they revalidated the Cerrado naked-tailed armadillo Cabassous squamicaudis which occurs in southern Bolivia. Finally, the genus Chlamyphorus was divided into two genera by Delsuc et al. (2012) and Smith \& Owen (2017), with the genus Calyptophractus replacing Chlamyphorus for the Chacoan fairy armadillo Calyptophractus retusus.

TABLE 1 presents an updated list of the armadillos of Bolivia, with eleven species in six of the eight recognized genera. Only the genera Chlamyphorus and Zaedyus have not been recorded for Bolivia (Aguirre et al., 2019).

In Bolivia, the Order Pilosa includes three species of anteaters: two representatives of the family Myrmecophagidae (the giant anteater Myrmecophaga tridactyla and the southern tamandua Tamandua tetradactyla) and one representative of the family Cyclopedidae (the Amboro silky anteater Cyclopes 
TABLE 1. Current recognized species of Xenarthra in Bolivia following Aguirre et al. (2019) with the exception of Cabassous squamicaudis following Feijó \& Anacleto (2021). Levels of threat follow the IUCN categorization (EN = Endangered; LC = Least Concern; NT = Near Threatened; VU = Vulnerable; DD = Data Deficient), and the Red List for Bolivia (MMAyA, 2009). Cabassous squamicaudis has not yet been evaluated for level of threat.

\begin{tabular}{|c|c|c|c|c|}
\hline Family-subfamily & Species recognized in Bolivia & Synonym & IUCN & Bolivia Red List \\
\hline \multirow{3}{*}{$\begin{array}{l}\text { Dasypodidae / } \\
\text { Dasypodinae }\end{array}$} & Dasypus beniensis & Dasypus kappleri beniensis & LC & NT \\
\hline & Dasypus novemcinctus & Dasypus novemcinctus novemcinctus & LC & LC \\
\hline & Dasypus septemcinctus & & LC & LC \\
\hline \multirow{3}{*}{$\begin{array}{l}\text { Chlamyphoridae / } \\
\text { Euphractinae }\end{array}$} & Chaetophractus vellerosus & $\begin{array}{l}\text { Including former } \\
\text { Chaetophractus nationi }\end{array}$ & LC & $\begin{array}{l}\text { C. vellerosus and C. nationi } \\
\text { are included in the Bolivia } \\
\text { Red List as NT and EN, } \\
\text { respectively }\end{array}$ \\
\hline & Chaetophractus villosus & & LC & NT \\
\hline & Euphractus sexcinctus & Euphractus sexcinctus boliviae & LC & LC \\
\hline \multirow{4}{*}{$\begin{array}{l}\text { Chlamyphoridae / } \\
\text { Tolypeutinae }\end{array}$} & Cabassous unicinctus & Cabassous unicinctus unicinctus & LC & DD \\
\hline & Cabassous squamicaudis & Cabassous unicinctus squamicaudis & - & - \\
\hline & Priodontes maximus & & VU & VU \\
\hline & Tolypeutes matacus & & NT & VU \\
\hline Cyclopedidae & Cyclopes catellus & Cyclopes didactylus catellus & LC & DD \\
\hline \multirow{2}{*}{ Myrmecophagidae } & Myrmecophaga tridactyla & & VU & NT \\
\hline & Tamandua tetradactyla & & LC & LC \\
\hline $\begin{array}{l}\text { Megalonychidae / } \\
\text { Choloepinae }\end{array}$ & Choloepus hoffmanni & & LC & $\mathrm{DD}$ \\
\hline Bradypodidae & Bradypus variegatus & & LC & LC \\
\hline
\end{tabular}

catellus; TABLE 1). The genera Myrmecophaga and Tamandua were studied using the entire mitochondrial genome, but the authors found no changes affecting the species present in Bolivia (Ruiz-García et al., 2021). The genus Cyclopes was revised by Miranda et al. (2018) using mitochondrial and nuclear DNA, species delimitation analysis, skull morphology, and pelage color and structure. They divided C. didactylus into seven species, with $C$. catellus being the species in Bolivia (TABLE 1).

Finally, there have been no changes in the number of sloth species present in Bolivia (TABLE 1). Two species of sloths continue to be recognized, including one representative of Megalonychidae (Hoffmann's two-toed sloth Choloepus hoffmanni) and one representative of Bradypodidae (the brown-throated three-toed sloth Bradypus variegatus) (Aguirre et al., 2019). However, a recent mitochondrial DNA study proposed that the morphological subspecies
B. variegatus boliviensis is invalid and Bolivian specimens belong to B. variegatus infuscatus (Ruiz-García et al., 2020).

\section{DISTRIBUTION}

The most recent evaluation of Bolivian medium and large-sized mammals (Wallace et al., 2010) and associated database (Wallace et al., 2013) updated the distribution records of Xenarthra in Bolivia. Here we combine those records with new records collected since 2012 (ANNEX 1, 2; TABLE 2). All distribution maps show records with high (direct observation, specimen collected, high-quality photographs) and medium taxonomic confidence (footprints, tracks, low quality photographs). New distribution records come from four principal sources: camera trap surveys, biodiversity studies, opportunistic visual records by field biologists, and iNaturalist (TABLE 2). Although the iNaturalist 
TABLE 2. New distributional records for Xenarthra species in Bolivia by method (the first three collected by field biologists).

\begin{tabular}{|c|c|c|c|c|}
\hline Species & Camera trap surveys & Biodiversity studies & $\begin{array}{l}\text { Opportunistic visual } \\
\text { records }\end{array}$ & iNaturalist \\
\hline Dasypus beniensis & 44 & 3 & - & - \\
\hline Dasypus novemcinctus & 276 & 14 & 1 & 7 \\
\hline Dasypus septemcinctus & 2 & 2 & 2 & 1 \\
\hline Chaetophractus vellerosus & - & 1 & 2 & 2 \\
\hline Chaetophractus villosus & - & - & - & - \\
\hline Euphractus sexcinctus & 8 & 11 & 1 & 11 \\
\hline Calyptophractus retusus & - & 2 & 1 & - \\
\hline Cabassous spp. & - & - & - & 2 \\
\hline Cabassous unicinctus & - & - & - & - \\
\hline Cabassous squamicaudis & - & - & - & - \\
\hline Priodontes maximus & 122 & 4 & 1 & 3 \\
\hline Tolypeutes matacus & - & 1 & - & 4 \\
\hline Cyclopes catellus & - & 1 & - & 3 \\
\hline Myrmecophaga tridactyla & 167 & 14 & 1 & 10 \\
\hline Tamandua tetradactyla & 51 & 11 & 5 & 11 \\
\hline Choloepus hoffmanni & - & - & 3 & 8 \\
\hline Bradypus variegatus & - & 3 & - & 29 \\
\hline
\end{tabular}

(https://www.inaturalist.org/) citizen science initiative provided abundant data over the last decade, especially at sites near urban areas, we included only records collected by biologists who use that platform, and after validation by the authors of this publication and other specialists. Below we summarize the new records by species.

\section{Dasypus beniensis \\ (Beni greater long-nosed armadillo)}

New records come from the Wildlife Conservation Society's (WCS) long-term camera trap studies in La Paz Department at Pampas del Heath, Madidi National Park and Integrated Management Area, as well as from the Pilón Lajas Biosphere Reserve and Communal Land in Beni Department (WCS, unpublished data). In addition, specimens collected in Beni Department initially reported as D. kappleri were reviewed and validated as D. beniensis by Feijó \& Cordeiro-Estrela (2016).

\section{Dasypus novemcinctus \\ (nine-banded armadillo)}

New records were obtained from WCS's longterm camera trap study in La Paz Department at Pampas del Heath, Madidi National Park and Integrated Management Area, as well as from the Pilón Lajas Biosphere Reserve and Communal Land in Beni Department (WCS, unpublished data). New records also come from sites in Beni Department along the Yacuma River (WCS, unpublished data), in the Great Tectonic Lakes of Exaltación Municipal Protected Area (Montaño, 2016; Ten et al., 2016; G. Ayala \& R. Wallace, pers. obs.), and at Barba Azul Nature Reserve in Yacuma municipality, that is part of the conservation area of the endemic blue-throated macaw (Ara glaucogularis) (Kingsbury, 2010, 2012). A long-term camera-trap study by the Andean Carnivore Conservation Program (PROMETA \& Museo d'Orbigny, Cochabamba) added new records in the dry forests of the central and southern 
Andes of Bolivia at Iñao National Park, Chuquisaca Department and in the San Lorenzo and Cercado provinces of Tarija Department (Velez-Liendo, pers. comm.). iNaturalist records come from Pando Department near Riberalta, Santa Cruz Department near Santa Cruz city, San Miguelito ranch in San Antonio de Lomerío municipality, San Carlos in Amboró Integrated Management Area, and Beni Department near Santa Rosa del Yacuma.

\section{Dasypus septemcinctus ( seven-banded armadillo)}

New records from Pampas del Heath, La Paz Department, as a result of the WCS's long-term camera trap study (Ayala et al., 2021), extend the known range of the species to northwestern Bolivia. Additional camera trap studies in the Llanos de Moxos in Beni Department provided new localities in the Yata basin (UAGRM \& FAUNAGUA, 2017), and in the Great Tectonic Lakes of Exaltación Municipal Protected Area (G. Ayala \& R. Wallace, pers. obs.). Opportunistic records by WCS researchers and others include photographs in grasslands along the Madidi River (La Paz and Beni Departments). An iNaturalist photo reviewed by Anderson Feijó extends this species' range to Pando Department in the extreme north of the country.

\section{Euphractus sexcinctus \\ ( six-banded armadillo)}

New records for Pampas del Heath, La Paz Department, extend the known range of the species to northwestern Bolivia (Ayala et al., 2021). Additional camera trap studies in the Llanos de Moxos in Beni Department reported new localities in the Great Tectonic Lakes of Exaltación Municipal Protected Area (G. Ayala \& R. Wallace, pers. obs.), and at Barba Azul Nature Reserve in Yacuma municipality that is part of the conservation area of the endemic blue-throated macaw (Ara glaucogularis) (Kingsbury, 2010, 2012). More records were added for the dry forests of the central and southern Andes of Bolivia at Iñao National Park, Chuquisaca Department from the long-term camera-trap study by the Andean Carnivore Conservation Program (Museo d'Orbigny, Cochabamba). iNaturalist records come from Vaca Diez, Yacuma and General José Ballivián provinces in Beni Department and from José Miguel de Velasco province in Santa Cruz Department.

\section{Chaetophractus vellerosus (screaming hairy armadillo)}

New records come from field researchers with the Proyecto Quirquincho (Museo d'Orbigny) in Santiago de Huari and Pampa Aullagas municipalities, Oruro Department (Quiroga \& Huayta, 2017); as well as from the boundary of the Kaa Iya National Park and Integrated Management Areas in Santa Cruz Department (Poma-Urey \&
Salazar-Miserendino, 2014). iNaturalist records come from Colcha " $\mathrm{K}$ " municipality in Nor Lípez province and from Uyuni municipality in Antonio Quijarro province, Potosí Department.

\section{Cabassous unicinctus \\ (southern naked-tailed armadillo); Cabassous squamicaudis \\ (Cerrado naked-tailed armadillo)}

These two species have no new records, and their distribution maps are based on Feijó \& Anacleto (2021), who validated the records for both species in Bolivia. The records published by Wallace et al. (2013) are classified as Cabassous spp. because the data are insufficient to confirm species. iNaturalist records include photos of a carapace of Cabassous without the head, from Riberalta in Pando Department, and from San Miguelito ranch, San Antonio de Lomerío municipality, in Santa Cruz Department.

\section{Calyptophractus retusus (greater fairy armadillo)}

Peñaranda Barrios (2020) reported several new records in the Chaco Dry Forest of Tarija Department from biodiversity studies funded by oil companies in their areas of operation.

\section{Tolypeutes matacus \\ (southern three-banded armadillo)}

New camera-trap records come from Cordillera province in Santa Cruz Department (Kosydar et al., 2018). iNaturalist records come from Charagua municipality and from San Miguelito ranch in San Antonio de Lomerío municipality in Santa Cruz Department; as well as from Gran Chaco province in Tarija Department.

\section{Priodontes maximus (giant armadillo)}

New records were reported at sites in Beni Department along the Yacuma River (WCS, unpublished data), and in the Great Tectonic Lakes of Exaltación Municipal Protected Area (Ten et al., 2016; G. Ayala \& R. Wallace, pers. obs.). iNaturalist records come from Abuná Province in Pando Department, Noel Kempff Mercado National Park (San Ignacio municipality), and San Miguelito ranch (San Antonio de Lomerío municipality) in Santa Cruz Department.

\section{Chaetophractus villosus (large hairy armadillo)}

It is noteworthy that the large hairy armadillo has not been recorded in Bolivia in the last 10 years. This may simply be an artefact of the distribution of recent field efforts, because the species was frequently collected by Isoseño hunters in the sand 
dune grasslands of southern Santa Cruz Department in the past (Noss et al., 2008).

\section{Cyclopes catellus \\ (Amboro silky anteater)}

Gutiérrez et al. (2020) reported two visual records of this species in the Piraí River Metropolitan Ecological Park, Santa Cruz Department. This park constitutes an ecotone between the metropolitan area of Santa Cruz de la Sierra and the remaining habitat for wildlife along the Piraí River. The two individuals were observed about $300 \mathrm{~m}$ from human habitation. iNaturalist records come from sites near Cobija in Pando Department, as well as from the municipality of Riberalta in Beni Department.

\section{Myrmecophaga tridactyla (giant anteater)}

There are new records from camera trap studies in the Llanos de Moxos of Beni Department in the Yata basin (UAGRM \& FAUNAGUA, 2017). New records have been reported at sites along the Yacuma River (WCS, unpublished data), within the Great Tectonic Lakes of Exaltación Municipal Protected Area, Beni Department (Montaño, 2016; G. Ayala \& R. Wallace, pers. obs.), and at Barba Azul Nature Reserve in Yacuma municipality that is part of the conservation area of the endemic blue-throated macaw (Ara glaucogularis) (Kingsbury, 2010, 2012). iNaturalist records come from Germán Busch and José Miguel de Velasco provinces in Santa Cruz Department; as well as from Yacuma, San Javier and General José Ballivián provinces in Beni Department.

\section{Tamandua tetradactyla (southern tamandua)}

There are new localities along the Yacuma River in the Llanos de Moxos in Beni Department (WCS, unpublished data), in the Great Tectonic Lakes of Exaltación Municipal Protected Area (Montaño, 2016; G. Ayala \& R. Wallace, pers. obs.), and at Barba Azul Nature Reserve in Yacuma municipality that is part of the conservation area of the endemic blue-throated macaw (Ara glaucogularis) (Kingsbury, 2010, 2012). Additional new records were added at El Palmar National Park, Lagarpampa-Mollepampa Municipal Protected Area, and in the San Lorenzo and Cercado provinces of Tarija Department from the long-term camera-trap study by the Andean Carnivore Conservation Program (Museo d'Orbigny, Cochabamba) (X. Velez-Liendo, pers. comm.). iNaturalist records include the northernmost location for the species, in Nicolás Suárez province, Pando Department; records from Nuflo de Chaves y Cercado, Santa Cruz Department; and others from Cercado and Yacuma provinces, Beni Department.

\section{Choloepus hoffmanni \\ (Hoffmann's two-toed sloth)}

WCS field staff obtained photographic records of one individual at the Santo Domingo community near Apolo, La Paz Department and another individual rescued by Madidi park guards on the Beni River (La Paz/Beni Departments). iNaturalist records come from Nicolás Suárez and Madre de Dios provinces in Pando Department, as well as from Vaca Díez province in Beni Department.

\section{Bradypus variegatus \\ (brown-throated three-toed sloth)}

Camera trap surveys in Yacuma municipality and the Great Tectonic Lakes of Exaltación Municipal Protected Area, Beni Department provided new records (Ten et al., 2016). iNaturalist records come from Vaca Díez, General José Ballivián, Mamoré and Cercado provinces in Beni Department, with many in and near the city of Trinidad; and also from Nuflo de Chaves, Ignacio Warnes, Sara and Andrés Ibañez provinces in Santa Cruz Department.

\section{ECOLOGY}

\section{Habitat selection}

No comprehensive population assessment or basic ecological study has been undertaken for any Xenarthra species in Bolivia in the past decade. However, recent studies have used camera traps to evaluate the effect of forest management activities on terrestrial mammals, including armadillos and anteaters. Arispe Liaños (2018) used camera traps at an Amazonian forest site in northern Santa Cruz Department to evaluate the effects of Forestry Stewardship Council (FSC) certified forest management on terrestrial mammals, including four armadillos (C. unicinctus, D. beniensis, D. novemcinctus, and P. maximus) and two anteaters (M. tridactyla and T. tetradactyla). However, with less than five records per species, comparative analyses could not be conducted for most of the species. For the two species with more than 10 records, $D$. novemcinctus and T. tetradactyla, the author did not detect any significant differences in abundance across forest blocks harvested recently ( $0-1$ year) versus blocks harvested previously (12-14 years).

Kosydar et al. (2014) combined camera traps with track plots at a Chiquitano Dry Forest site (mosaic of protected forest, cattle ranch, and mechanized agriculture) to evaluate the effects of hunting and forest fragmentation on species abundance and richness. Overall, they recorded four armadillo species (D. novemcinctus, E. sexcinctus, T. matacus, and P. maximus) and two anteater species (M. tridactyla and T. tetradactyla). Only D. novemcinctus provided sufficient records for comparative analysis, and the 
differences were not significant between hunted, fragmented, and protected sites. When grouping the records, the four armadillos had reduced abundance in hunted areas, but the two anteaters did not.

Comparing certified timber extraction operations across four countries-Bolivia, French Guiana, Nicaragua, and Guatemala-Polisar et al. (2016) used systematic camera trap survey data to examine the benefits of certification for jaguar conservation specifically and for other species incidentally. They grouped the Xenarthra together, and for the three Chiquitano Dry Forest concessions in Bolivia, they reported xenarthrans to be most abundant at the site with more hunting, fragmentation, and fires. They went further, and proposed D. novemcinctus as a possible candidate for managed hunting by local communities because of the species' high reproductive rate and generalist habitat preferences, although this recommendation is not specific to the Bolivian sites.

Pérez-Zubieta (2011) conducted a field study of highland C. vellerosus (formerly C. nationi) habitat use in the Altiplano of Oruro Department. He monitored track plots and armadillo signs in three types of plots: cultivated potato (Solanum tuberosum) fields, sand dunes, and grasslands. He found more armadillo foraging activity in cultivated fields and in sand dunes as opposed to grasslands, and more armadillo burrows in sand dunes. Real or perceived crop damage fosters negative feelings from local farmers and the author suggested working with them to design and implement appropriate conservation measures.

Quiroga \& Huayta (2017) built single-season occupancy models for C. vellerosus in the municipalities of Huari, Pampa Aullagas, and Orinoca in Oruro Department. In contrast to Pérez-Zubieta (2011), the models suggested that armadillos avoided cultivated areas and preferred a more mixed environment consisting of sand dunes with the presence of Festuca dolichophylla (Poaceae) and Baccharis incarum (Asteraceae). However, the biggest difference between the two studies was that, in the former, the cultivated fields were dominated by quinoa. This difference might suggest an armadillo preference for certain crops, which could potentially affect the level of conflict, either perceived or real, with farmers.

\section{Predation}

Flores-Turdera et al. (2021) completed a study of food habits of jaguar and puma (Puma concolor) in the lower Tuichi and Hondo Rivers in Madidi National Park and Integrated Management Area and Pilón Lajas Biosphere Reserve. They found that Xenarthra were rare prey species: $M$. tridactyla for jaguar; T. tetradactyla and B. variegatus for puma.
A curious predator-prey relationship was noted by Berkunsky et al. (2012) who found two D. novemcinctus and two E. sexcinctus in the nest of a crowned eagle (Urubitinga coronata) in the Moxos savannas of Beni Department. Armadillos have been reported as prey for this eagle elsewhere (Maceda et al., 2003; Pereyra Lobos et al., 2011), and the authors thought that armadillos may be particularly important prey in the breeding season.

\section{Diet}

Wallace \& Painter (2013) reported frugivory by P. maximus in Amazonian forests of Bolivia. The stomach of an individual killed by a subsistence hunter contained exclusively unidentified figs ( $F i$ cus sp.), while at another site they observed feeding signs of the giant armadillo under fig trees.

\section{Behavior}

To better manage a captive population of $C$. vellerosus, de la Quintana et al. (2017) evaluated agonistic behaviors of 12 individuals in the Municipal Zoo Vesty Pakos in La Paz, Bolivia. Agonistic behaviors among males, when several were housed together, included growling, head-butting or body-slamming, and chasing. The most aggressive male did not tolerate any other male, whereas the other males could be habituated to each other and live in pairs. Females were not aggressive to each other.

A spool-and-thread study of T. matacus in the Chaco provided information on daily displacement, burrow and nest use, and feeding behavior (Noss, 2013). The method provided a maximum of five days of tracking, and the $350 \mathrm{~m}$ daily thread was frequently fully drawn out or broken in a single day. Animals slept in nests of dry leaves, dense bromeliads, or burrows of other animals. Observed signs suggested that animals were feeding principally on insects, including termites, and on plants.

\section{THREATS}

\section{Habitat loss}

As elsewhere, deforestation is a major threat to xenarthrans, especially to sloths. Pressures in the lowlands (Amazon forest, Llanos de Moxos savanna, Chiquitano dry forest, Chaco, and Pantanal) are also increasing as a result of economic pressures, policy changes, and frequent fires in the past decade. The modeling work of Romero-Muñoz et al. (2020, see below) found that habitat destruction was the main driver for the shrinkage of high-quality habitat for xenarthrans. International markets for soy and beef have driven the conversion of forests and savannas to farms and ranches, and the construction and improvement of roads (Fehlenberg et al., 2017). Government policy has further 


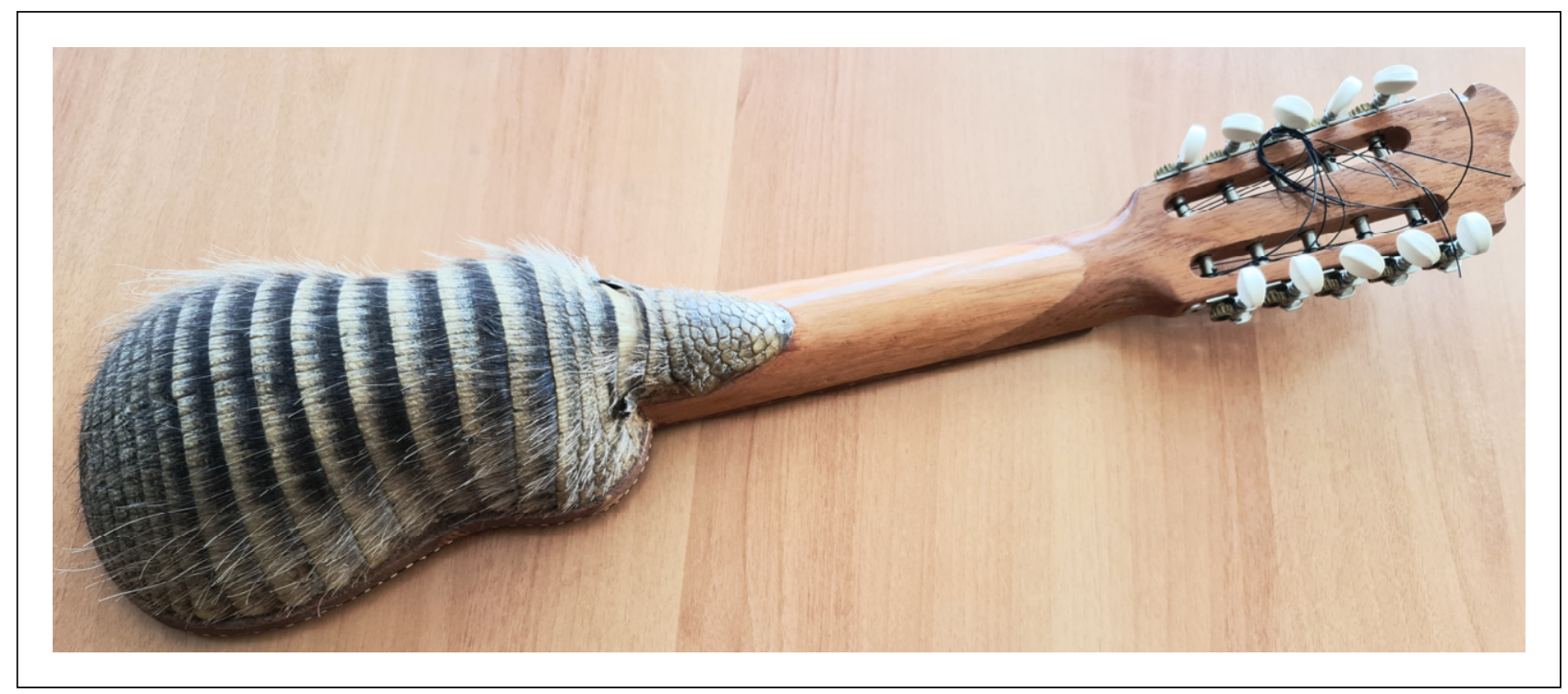

FIGURE 1. Traditional instrument, the charango, using mainly C. vellerosus, formerly C. nationi.

fomented conversion by modifying the ecological zoning from forest land use categories to agriculture. Government policy has also promoted the re-settlement of highland farmers into the lowlands; these colonists clear natural habitats for their settlements and farms (Colque et al., 2019).

Fire is used every year to clear pastures and fields, particularly in savanna formations. However, fires from July to September 2019 were especially severe in Bolivia, with over 5 million ha burned; $74 \%$ of this area was forest as opposed to grasslands. Fires spread into national, departmental, and municipal protected areas, as well as indigenous territories and private lands (Anívarro et al., 2019; NATIVA, 2019a). The severity of the fires was attributed to the coincidence of environmental conditions (drought and winds) with the socio-economic pressures described above (Colque et al., 2019), and the legalization of "controlled burns" in lowland forests (NATIVA, 2019b; Romero-Muñoz et al., 2019). Fires continued to be severe in 2020 and 2021, with unpublished government reports of M. tridactyla, T. tetradactyla, and several species of armadillos burned, and some survivors killed by illegal hunters while escaping the fires (E. Aliaga-Rossel, pers. obs.). Initial analyses of the effects of the fires on wildlife have focused on the jaguar as the umbrella species (Anívarro et al., 2019), but also noted that IUCN Vulnerable species including M. tridactyla and P. maximus were affected (WCS, 2020). News reports also highlighted jaguars, but they did mention anteaters and armadillos among other affected species that were killed or displaced (CE Noticias Financieras, 2019; International Business Times, 2019).

\section{Hunting}

The majority of species of both the Cingulata and Pilosa are affected by hunting. Armadillos, especially Dasypus and Priodontes, are used as a protein source by indigenous and local people throughout their ranges (Noss et al., 2008; Aliaga-Rossel, 2011, ASASG, 2021). Indeed, over the last 30 years, the spatial impact of hunting pressure across the Gran Chaco was as large as that of habitat destruction for xenarthrans (Romero-Muñoz et al., 2020; see below). The law permits subsistence hunting of these species, although some studies show that hunting is not always sustainable (Fragoso et al., 2000; AliagaRossel, 2011), in particular with the acculturation of indigenous people and isolated rural populations. The change from subsistence to commercial armadillo hunting is evident, with armadillos being sold at bus stops in the lowlands along the roads from Cochabamba to Santa Cruz.

In a review of how hunting dogs affect wildlife, Koster \& Noss (2013) re-evaluated hunting records from Isoseño-Guaraní indigenous communities in the Bolivian Chaco. Five armadillo species are commonly hunted for subsistence: $D$. novemcinctus, E. sexcinctus, C. villosus, C. vellerosus, and T. matacus. Dogs were particularly effective at locating the three nocturnal armadillos (D. novemcinctus, C. villosus, T. matacus), and two or more dogs were more effective than a single dog. Although they were not consumed, the anteaters M. tridactyla and T. tetradactyla were occasionally chased and killed by hunting dogs, or killed by the hunters in order to protect the dogs from harm. Researchers here also used local hunters with trained dogs to capture $D$. novemcinctus and T. matacus alive for abundance and health studies (Cuéllar, 2002; Deem et al., 2009). 
Armadillos continue to be hunted for cultural purposes, most importantly quirquincho (C. vellerosus) carapaces for the fabrication of charangos and matracas (Romero-Muñoz \& Pérez-Zubieta, 2008; Fobar, 2019). The charango (FIG. 1) is a small Andean stringed instrument of the lute family, which probably originated by copying guitars during the colonial period. Matracas are rattles used in a traditional dance called the Morenada, performed by hundreds of dancers. Between 2008 and 2009, Porcel (2012) counted over 900 dancers at the Oruro carnival event using matracas made with the carapaces of armadillos. In interviews, many dancers commented that they tend to lose the matracas, break them while dancing, or that they simply have more than one. In a similar study in 2014, Quiroga (2015) counted over 1,500 dancers using matracas.

In order to address this problem, the government made it illegal in 2015 to sell or possess a new matraca (Fobar, 2019). Therefore, in 2016 the Oruro Folklore Groups Association (Asociación de Conjuntos Folklóricos de Oruro or ACFO) declared to the General Biodiversity and Protected Areas Directorate the use of 2,084 matracas (F. Suárez, pers. comm.). Under Administrative Resolution VMABCCGDF No. 004/18 (MMAyA, 15 January 2018) and Inter-Institutional Agreement No. 163 between ACFO, the Ministry of Environment and Water (MMAyA), and the Ministry of Cultures and Tourism, matracas were registered for all dancers in 2019. The agreement seeks to prevent, catalog, regulate, replace, and eliminate the use of wildlife specimens and products in all cultural activities in which ACFO participates. Although the laws forbid and regulate illegal trafficking, the deep-rooted cultural meaning of this species, especially for people living in the High Andes, in addition to a lack of enforcement, make quirquincho hunting a challenge that needs more creative thinking. Quiroga (2015) found that quirquinchos were still widely available in small markets, as they are also used as good luck charms, and to date we do not know whether the demand for these products has decreased or continues. In the lowlands, D. novemcinctus tails are sold as key chains.

\section{Synergistic effects of habitat destruction and hunting}

An expansive modeling study, in both geographic and temporal scales, evaluated the effects of habitat destruction and hunting, acting separately and synergistically, on mammals across the three-nation Gran Chaco region from 1985 to 2015 (Romero-Muñoz et al., 2020). Covering 1.1 million $\mathrm{km}^{2}$, the Gran Chaco became a global hotspot of deforestation due to the expansion of beef and soy agriculture (Hansen et al., 2013). The study combined habitat suitability with hunting-pressure models to map the change in the footprints of both threats, and the consequent change in high-quality habitat over three decades for 48 medium and large-sized mammals with sufficient data to produce reliable habitat models, including eight armadillo and two anteater species. Among sloth species, only B. variegatus reaches the Chaco, but only marginally, and was excluded from the analysis due to insufficient records. On average, xenarthran species lost 3.5\% \pm 25.4 SD of their high-quality habitat between 1985 and

TABLE 3. Percent change in threats affecting Xenarthra in the Gran Chaco region from 1985 to 2015. Major threats were loss of high-quality habitat, hunting pressure, habitat destruction, and the combined effect of hunting pressure and habitat destruction. Source: Romero-Muñoz et al. (2020).

\begin{tabular}{ccccc}
\hline Species & High-quality habitat & Hunting & Habitat destruction & Both threats \\
\hline Dasypus novemcinctus & -17.3 & 5.7 & 118.3 & 110.7 \\
Chaetophractus vellerosus & 40.7 & 39.5 & -27.3 & 3.6 \\
Chaetophractus villosus & 6.4 & 17.2 & 2.9 & 11.0 \\
Euphractus sexcinctus & -1.6 & 0.6 & 10.0 & 23.8 \\
Calyptophractus retusus & 31.6 & 17.9 & 20.9 & 29.7 \\
Priodontes maximus & -55.9 & 43.4 & -10.4 & 47.0 \\
Tolypeutes matacus & -5.1 & 18.1 & 15.3 & 94.8 \\
Myrmecophaga tridactyla & -6.5 & 12.9 & 56.2 & 21.7 \\
Tamandua tetradactyla & -10.8 & 8.2 & 6.6 & \\
\hline
\end{tabular}


2015 (TABLE 3). This value is somewhat misleading because three species-C. vellerosus, $C$. villosus, and Cal. retusus-gained high-quality habitat. However, for the remaining seven species that lost high quality habitat the average loss was $16 \%$. Priodontes maximus lost the most high-quality habitat (55\%), followed by $D$. novemcinctus ( $17 \%$ loss), while M. tridactyla and T. tetradactyla lost $6.5 \%$ and $10.8 \%$ of their habitat, respectively (TABLE 3). On average for all xenarthrans, the footprint of habitat destruction increased by $17 \%$ over this period, that of hunting by $22 \%$, and that of both threats acting together by $42 \%$.

\section{Roadkills}

The construction of new paved roads and the paving of dirt roads, for example the new San Ignacio-Trinidad and San Borja-Yucumo roads in Beni Department, have increased the number of armadillos, sloths, and anteaters killed by vehicles (E. Aliaga-Rossel, pers. obs.). Also, as mentioned previously, animals fleeing forest fires were hit by vehicles. Precise figures for this mortality are not available, but the problem requires further investigation.

\section{Conservation Status}

The recent Supreme Decree 4489 (April 2021) forbids any form of sport hunting in the country, as well as activities related to trade, trafficking, or keeping wild animals as pets. However, the lack of enforcement and public dissemination of the law reduces the effectiveness of this Supreme Decree.

Overall, the conservation status for Xenarthra species in Bolivia is thought to be relatively stable, with vast protected areas (national, departmental, municipal, and private), indigenous territories, and certified forestry concessions where deforestation and hunting are limited. However, some ecoregions are especially threatened. For example, less than $4 \%$ of the inter-Andean Dry Valleys are under some form of protection. Similarly, the vast Llanos de Moxos savannas are poorly represented by national protected areas. Outside of protected areas, the threats are those described above for all species, especially habitat destruction and road kills, as well as hunting of some armadillos for subsistence purposes. It is not currently possible to quantify the increasing number of wildlife killed by fires, traffic, and illegal hunting. In an attempt to model the potential scenarios for the Bolivian Amazon under future land cover change and climate change, Osipova \& Sangermano (2016) used T. tetradactyla, the jaguar, and the lowland tapir (Tapirus terrestris) as a multi-species umbrella, projecting losses of between $70 \%$ and $83 \%$ of their ranges by 2050 .

A positive response to the pressures described above is the creation of new protected areas, most notably Ñembi Guasu (1.2 million ha) and
Guajukaka $(285,000$ ha) by the indigenous municipality of Charagua (Santa Cruz Department). Charagua Iyambae is Bolivia's first legally recognized Autonomous Indigenous Native Campesino municipality, established by the Guaraní indigenous people. The two new protected areas in the Bolivian Chaco connect Otuquis and Kaa-Iya National Parks in Bolivia with Paraguay's Héroes del Chaco Departmental Reserve. These new areas extend legal protection to all the Chaco Xenarthra, with T. tetradactyla, M. tridactyla, and P. maximus cited as vulnerable species that benefit from the new protected areas (Arnold \& Brown, 2018; NATIVA, 2019a,b; Sierra Praeli, 2019a,b). Sadly, to date more than 250,000 hectares of forest in Nembi Guasu were burned and destroyed in the fires described above, affecting all the wildlife present (NATIVA, 2019b).

\section{CONCLUSIONS}

Few researchers in Bolivia are working directly with Xenarthra species, and efforts should be made to encourage the design of field research focused on the new protected areas mentioned above. Records that are by-catch data from studies focused on other species do not provide adequate ecological data to guide effective site-specific conservation measures for Xenarthra in Bolivia. Therefore, specific longterm field studies on habitat preference, distribution, and population trends should be prioritized.

Because C. nationi is no longer recognized as a species endemic to the Bolivian Andes, having been lumped with a more widespread species, it is no longer considered threatened (Vulnerable) by the IUCN. As a result, researchers will face increased difficulties in obtaining funding and generating interest to study this species (Foban, 2019). Officially, the Red List of Vertebrates of Bolivia (MMAyA, 2009) still considers the Andean hairy armadillo (C. nationi) to be endangered, and government legislation focuses specifically on reducing quirquincho exploitation for cultural purposes. The Red List is also over a decade old, and should be updated with systematic evaluations of threats facing each species of Xenarthra today.

Support from government agencies and national and international NGOs to implement protected areas and landscape management activities continue. These efforts, although they benefit Xenarthra in general, focus on emblematic species such as jaguars or threatened habitats, and are not specifically directed to Xenarthra.

New records of Xenarthra were obtained from lesser known or neglected ecosystems such as the Inter-Andean Dry Forests and the Bolivian-Tucumán Forest. The number of threatened ecosystems is increasing, and some are more vulnerable to recurrent forest fires as well as to continuous and frequent 
droughts, such as the High Andean Sand Dunes, Chiquitano Dry Forest, and Bolivian-Tucumán Forest. Further research and conservation efforts should be focused in these ecosystems.

Future research priorities for xenarthrans in Bolivia should include further distribution studies because recent taxonomic changes and known global distributions suggest that at least four additional species could possibly occur in the country. For Cingulata, given nearby records in northern Argentina, it seems probable that the Yungas lesser long-nosed armadillo (Dasypus mazzai) may be present in the extreme south of Bolivia in Tarija Department (Wallace \& Porcel, 2010). Similarly, in the southern portion of the Bolivian Chaco it is very possible that, if Cabassous is present, then the species would be the Chacoan naked-tailed armadillo C. chacoensis, based on Paraguayan records (Wallace \& Porcel, 2010; Smith \& Rios, 2018). For Pilosa, the recent taxonomic revision for Cyclopes (Miranda et al., 2018) is likely to yield additional species for Bolivia. For example, unconfirmed photographic records suggest that the red silky anteater $C$. rufus and Thomas' silky anteater $C$. thomasi may both be present in the north of the country (RAI, 2018).

Finally, the COVID-19 pandemic has changed lives as well as worldwide views on biodiversity, given the possible zoonotic origin of the virus. Preserving biodiversity should be a public health priority. As conservationists, we must increase knowledge and protection of Xenarthra species and their habitats. Our efforts can also benefit from coordination with global initiatives like the UN Decade of Ecosystem Restoration in order to prevent, halt, and reverse the degradation of our ecosystems.

\section{ACKNOWLEDGEMENTS}

We thank all the National Park rangers, in their far-flung and isolated posts, who are committed to protect the biodiversity of the country. We thank Eric Yensen for reading the draft of the manuscript and providing suggestions. We also thank Anderson Feijó for reviewing Dasypus septemcinctus photos. We thank Jim Loughry, Paul Smith, and an anonymous reviewer for their thoughtful revisions.

\section{REFERENCES}

Abba, A.M., et al. 2015. Systematics of hairy armadillos and the taxonomic status of the Andean hairy armadillo (Chaetophractus nationi). Journal of Mammalogy 96: 673-689. https://doi.org/10.1093/jmammal/ gyv082

Aguirre, L.F., et al. 2019. Lista actualizada y comentada de los mamíferos de Bolivia/Updated and annotated check list of mammals from Bolivia. Ecología en Bolivia 54: 107-147.
Aliaga-Rossel, E. 2011. The cascading effect of mammal species defaunation on seed and seedling survivorship as a result of hunting. Doctoral dissertation, University of Hawaii, Manoa. 148 pp.

Anívarro, R., H. Azurduy, O. Maillard, A. Markos \& A. Barrero. 2019. Diagnóstico por teledetección de áreas quemadas en la Chiquitanía. Informe Técnico. Observatorio Bosque Seco Chiquitano, FCBC, Santa Cruz, Bolivia. 70 pp.

Arispe Liaños, M. R. 2018. Efecto en el tiempo del manejo forestal: la respuesta de una comunidad de mamíferos terrestres en un bosque certificado de Bolivia. MSc thesis, Universidad Autónoma Gabriel René Moreno, Santa Cruz, Bolivia. 52 pp.

Arnold, I. \& A. Brown. 2018. Evaluación del Gran Chaco americano. NATIVA, Tarija, Bolivia. 148 pp.

ASASG-Anteater, Sloth \& Armadillo Specialist Group. 2021. Armadillos. https://www.xenarthrans.org/species/armadillos-2/ Accessed on 4 November 2021.

Ayala, G.M., M.E. Viscarra \& R.B. Wallace. 2021. First records of the seven-banded armadillo (Dasypus septemcinctus) and the six-banded armadillo (Euphractus sexcinctus) in northeastern Bolivia. Edentata 22: 42-46. https://doi.org/10.2305/IUCN.CH.2021. Edentata-20-1.6.en

Berkunsky, I., et al. 2012. Records of the crowned eagle (Urubitinga coronata) in Moxos plains of Bolivia and observations about breeding behavior. Revista Brasileira de Ornitologia 20: 447-450.

CE Noticias Financieras. 2019. Species such as jaguar, in the shadow of death. CE Noticias Financieras. 15 September 2019.

Colque, G., E. Tinta, A. Moy, S. Muiba, S. Velasco \& F. Alcons. 2019. Fuego en Santa Cruz: balance de los incendios forestales 2019 y su relación con la tenencia de la tierra. Informe Especial. Fundación Tierra, La Paz, Bolivia. 96 pp.

Cuéllar, E. 2002. Census of the three-banded armadillo Tolypeutes matacus using dogs, southern Chaco, Bolivia. Mammalia 66: 448-451.

de la Quintana, P., G. Ledezma \& L.F. Pacheco. 2017. Evaluación del comportamiento agonista de quirquinchos (Chaetophractus vellerosus) en el Zoológico Municipal Vesty Pakos, La Paz, Bolivia. Edentata 18: 34-41. https://doi.org/10.2305/IUCN.CH.2017. Edentata-18-1.5.en

Deem, S.L., A.J. Noss, C.V. Fiorello, A. L. Manharth, R. G. Robbins \& W.B. Karesh. 2009. Health assessment of free-ranging three-banded (Tolypeutes matacus) and nine-banded (Dasypus novemcinctus) armadillos in the Gran Chaco, Bolivia. Journal of Zoo and Wildlife Medicine 40: 245-256. https://doi. org/10.1638/2007-0120.1

Delsuc, F., M. Superina, M.K. Tilak, E.J. Douzery \& A. Hassanin. 2012. Molecular phylogenetics unveils the ancient evolutionary origins of the enigmatic fairy armadillos. Molecular Phylogenetics and 
Evolution 62: 673-680. https://doi.org/10.1016/j. ympev.2011.11.008

Fehlenberg, V., M. Baumann, N.I. Gasparri, M. Piquer-Rodrigueza, G. Gavier-Pizarrod \& T. Kuemmerle. 2017. The role of soybean production as an underlying driver of deforestation in the South American Chaco. Global Environmental Change 45: 24-34. https:// doi.org/10.1016/j.gloenvcha.2017.05.001

Feijó A. \& T.C. Anacleto. 2021. Taxonomic revision of the genus Cabassous McMurtrie, 1831 (Cingulata: Chlamyphoridae), with revalidation of Cabassous squamicaudis (Lund, 1845). Zootaxa 4974: 47-78. https://doi.org/10.11646/zootaxa.4974.1.2

Feijó A. \& P. Cordeiro-Estrela. 2016. Taxonomic revision of the Dasypus kappleri complex, with revalidations of Dasypus pastasae (Thomas, 1901) and Dasypus beniensis Lönnberg, 1942 (Cingulata, Dasypodidae). Zootaxa 4170: 271-297. https://doi.org/10.11646/ zootaxa.4170.2.3

Feijó, A., B.D. Patterson \& P. Cordeiro-Estrela. 2018. Taxonomic revision of the long-nosed armadillos, Genus Dasypus Linnaeus, 1758 (Mammalia, Cingulata). PLoS One 13: e0195084. https://doi.org/10.1371/ journal.pone.0195084

Feijó, A., et al. 2019. Phylogeny and molecular species delimitation of long-nosed armadillos (Dasypus: Cingulata) supports morphology-based taxonomy. Zoological Journal of the Linnean Society 186: 813825. https://doi.org/10.1093/zoolinnean/zly091

Flores-Turdera, C., G. Ayala, M. Viscarra \& R. Wallace. 2021. Comparison of big cat food habits in the Amazon piedmont forest in two Bolivian protected areas. Therya 12: 75-83. https://doi.org/10.12933/ therya-21-1024

Fobar, R. 2019. Bolivia: armadillos en peligro de extinción utilizados como instrumentos musicales de carnaval. National Geographic LA Newsletter. https://www. nationalgeographicla.com/animales/2019/02/ bolivia-armadillos-en-peligro-de-extincion-utilizados-como-instrumentos-musicales. Accessed on 19 October 2021.

Fragoso, J.M.V., K. M. Silvius \& M. Villa-Lobos, M. 2000. Wildlife management at the Rio das Mortes Xavante Reserve, MT, Brazil: integrating indigenous culture and scientific method for conservation. World Wildlife Fund - Brazil, Brasilia, Brazil. Vol. 4. 68 pp.

Gutiérrez, E.K., D. García, M.A. Pinto-Viveros \& E. Caballero. 2020. Registro de dos ositos de oro (Cyclopes Gray, 1821) en el Cordón Ecológico del Río Piraí, Santa Cruz de la Sierra (Bolivia) y aportes para su conservación. Kempffiana 16: 35-46.

Hansen, M.C., et al. 2013. High-resolution global maps of $21^{\text {st }}$-century forest cover change. Science 342 : 850-853. https://doi.org/10.1126/science.1244693

International Business Times. 2019. More than 2 million animals perish in Bolivia wildfires. International Business Times [U.S. ed.], 26 Sept. 2019, p. NA. Gale Academic OneFile. https://link.gale.com/apps/doc/
A600760912/AONE?u=gain40375\&sid=AONE \& $x-$ $\mathrm{id}=\mathrm{d} 6175008$. Accessed 16 September 2020.

Kingsbury, J. 2010. Bolivia 2010 Expedition report, a joint Glasgow University \& Bolivian expedition to the Beni Savannahs of Bolivia. Informe Técnico. Glasgow University Exploration Society. 110 pp.

Kingsbury, J. 2012. Bolivia 2012 Expedition report, a joint Glasgow University \& Bolivian expedition to the Beni Savannahs of Bolivia. Informe Técnico. Glasgow University Exploration Society. 114 pp.

Koster, J. \& A. Noss. 2013. Hunting dogs and the extraction of wildlife as a resource. Pp. 265-285 in: Free-ranging dogs and wildlife conservation (M.E. Gompper, ed.). Oxford University Press, Oxford. https://doi. org/10.1093/acprof:osobl/9780199663217.003.0011

Kosydar, A.J., D.I. Rumiz, L.L. Conquest \& J.J. Tewksbury. 2014. Effects of hunting and fragmentation on terrestrial mammals in the Chiquitano forests of Bolivia. Tropical Conservation Science 7: 288-307. https://doi.org/10.1177/194008291400700209

Maceda, J.J., J.H. Sarasola \& M.E. María Pessino. 2003. Prey consumed by the Crowned Eagle (Harpyhaliaetus coronatus) in the southern limits of its range in Argentina. Ornitología Neotropical 14: 419-422.

Miranda, F. R., D.M. Casali, F. A. Perini, F.A. Machado \& F.R. Santos. 2018. Taxonomic review of the genus Cyclopes Gray, 1821 (Xenarthra: Pilosa), with the revalidation and description of new species. Zoological Journal of the Linnean Society 183: 687-721. https://doi.org/10.1093/zoolinnean/zlx079

MMAyA - Ministerio de Medio Ambiente y Agua. 2009. Libro Rojo de la fauna silvestre de vertebrados de Bolivia. MMAyA, La Paz, Bolivia. 572 pp.

Montaño, R.R. 2016. Estudio técnico científico para el conocimiento y la consolidación del APM-ANMI Grandes Lagos Tectónicos de Exaltación, provincia Yacuma, departamento del Beni, Bolivia. CIBIOMA \& Universidad Autónoma Gabriel René Moreno, Santa Cruz de la Sierra. 90 pp.

NATIVA. 2019a. El Chajá No 74: Especial Incendios. Revista Informativa sobre Medio Ambiente y el Trabajo de NATIVA. Tarija, Bolivia. 43 pp.

NATIVA. 2019b. El Chajá No 72. Revista Informativa sobre Medio Ambiente y el Trabajo de NATIVA. Tarija, Bolivia. 22 pp.

Noss, A. J. 2013. Seguimiento del corechi (Tolypeutes matacus) por medio de carreteles de hilo en el Chaco boliviano. Edentata 14: 15-22. https://doi.org/10.5537/ 020.014.0103

Noss, A.J., R.L. Cuéllar \& E. Cuéllar. 2008. Exploitation of xenarthrans by the Guaraní-Isoseño indigenous people of the Bolivian Chaco: comparisons with hunting by other indigenous groups in Latin America, and implications for conservation. Pp. 244-254 in: The biology of the Xenarthra (S.F. Vizcaíno and W.J. Loughry, eds.). University of Florida Press, Gainesville. 
Noss, A., E. Cuéllar, H. Gómez, T. Tarifa \& E. AliagaRossel. 2010a. Dasypodidae. Pp. 173-212 in: Distribución, ecología y conservación de los mamíferos medianos y grandes de Bolivia (R. B. Wallace, H. Gómez, Z. R. Porcel \& D. I. Rumiz, eds.). Centro de Ecología Difusión Simón I. Patiño, Santa Cruz, Bolivia.

Noss, A., E. Cuéllar, H. Gómez, T. Tarifa, J. Vargas \& E. Aliaga-Rossel. 2010b. Myrmecophagidae Cyclopedidae - Bradypodidae - Megalonychidae. Pp. 213-234 in: Distribución, ecología y conservación de los mamíferos medianos y grandes de Bolivia (R.B. Wallace, H. Gómez, Z.R. Porcel \& D.I. Rumiz, eds.). Centro de Ecología Difusión Simón I. Patiño, Santa Cruz, Bolivia.

Osipova, L. \& F. Sangermano. 2016. Surrogate species protection in Bolivia under climate and land cover change scenarios. Journal for Nature Conservation 34: 107-117. https://doi.org/10.1016/j.jnc.2016.10. 002

Peñaranda Barrios, E.M. 2020. Nuevos registros del pichiciego mayor, Calyptophractus retusus (Cingulata: Dasypodidae), en el Chaco tarijeño de Bolivia. Acta Zoológica Lilloana 64: 58-64. https://doi.org/10. 30550/j.azl/2020.64.1/5

Pereyra Lobos, R., F.J. Santander, S. Alvarado Orellana, P. A. Ramírez, L. Muñoz \& D. Fernández Bellón. 2011. Diet of the Crowned Eagle (Harpyhaliaetus coronatus) during the breeding season in the Monte Desert, Mendoza, Argentina. Journal of Raptor Research 45: 180-183. https://doi.org/10.3356/JRR-10-36.1

Pérez-Zubieta, J.C. 2011. Intensidad de uso de hábitat del Quirquincho Andino (Chaetophractus nationi) en zonas aledañas a asentamientos humanos de la Provincia Sur Carangas, Oruro, Bolivia. Edentata 12: 28-35. https://doi.org/10.5537/020.012.0105

Polisar, J., et al. 2016. Using certified timber extraction to benefit jaguar and ecosystem conservation. Ambio 46: 588-603. https://doi.org/10.1007/s13280-0160853-y

Poljak, S., A.M. Ferreiro, M.B. Chiappero, J. Sánchez, M. Gabrielli \& M.S. Lizarralde. 2018. Phylogeography of screaming hairy armadillo Chaetophractus vellerosus: successive disjunctions and extinctions due to cyclical climatic changes in southern South America. PLoS One 13: e0190944. https://doi.org/ 10.1371/journal.pone.0190944

Poma-Urey, J.L. \& R.S. Miserendino-Salazar. 2014. Avistamientos de una peji (Euphractus sexcinctus Linnaeus, 1758) llevando su cría. Edentata 15: 66-68. https://doi.org/10.5537/020.015.0110

Porcel, Z.R. 2012. Estimación de la tasa de extracción del quirquincho andino (Chaetophractus nationi) y su red de suministro y comercialización en el Departamento de Oruro. Tesis de Licenciatura, Universidad Mayor de San Andrés, La Paz, Bolivia. 46 pp.

Quiroga, C.J. 2015. Converting cultural value to conservation value: Finding a conservation "niche" for the Andean hairy armadillo. Master's thesis, University of Kent, Canterbury, United Kingdom. 36 pp.
Quiroga, C.J. \& G. Huayta. 2017. Cacería, conflicto o pérdida de hábitat. Qué está causando el declive en la población de Quirquinchos (Chaetophractus nationi). Informe Técnico. Museo de Historia Natural "Alcide d'Orbigny", Cochabamba, Bolivia. 13 pp.

RAI - Red Ambiental de Información. 2018. Descubren dos nuevas especies de osos oro en la Amazonía boliviana. http://www.raibolivia.org/descubren-dosnuevas-especies-de-ositos-oro-en-la-amazonia/. Accessed on 15 October 2021.

Romero-Muñoz, A., et al. 2020. Increasing synergistic effects of habitat destruction and hunting on mammals over three decades in the Gran Chaco. Ecography 43: 954-966. https://doi.org/10.1111/ecog.05053

Romero-Muñoz, A., M. Jansen, A. M. Nuñez, M. Toledo, R. Vides Almonacid \& T. Kuemmerle. 2019. Fires scorching Bolivia's Chiquitano forest. Science 29 Nov 2019: 1082. https://doi.org/10.1126/science.aaz7264

Romero-Muñoz, A. \& J.C. Pérez-Zubieta. 2008. Evaluación preliminar del comercio y uso de mamíferos silvestres en el mercado La Pampa de la ciudad de Cochabamba, Bolivia. Mastozoología Neotropical 15: 253-259.

Ruiz-García, M., D. Chacón, T. Plese \& J. M. Shostell. 2020. Molecular phylogenetics of Bradypus (Three-toed sloth, Pilosa: Bradypodidae, Mammalia) and phylogeography of Bradypus variegatus (Brown-throated three-toed sloth) with mitochondrial gene sequences. Journal of Mammalian Evolution 27: 461-482. https://doi.org/10.1007/s10914-019-09465-w

Ruiz-García, M., D. Pinilla-Beltrán, O.E. Murillo-García, C.M. Pinto, J. Brito \& T.M. Shostell. 2021. Comparative mitogenome phylogeography of two anteater genera (Tamandua and Myrmecophaga, Myrmecophagidae, Xenarthra): Evidence of discrepant evolutionary traits. Zoological Research 42: 525-547. https://doi.org/10.24272/j.issn.2095-8137.2020.365

Sierra Praeli, Y. 2019a. Nembi Guasu: Huge new conservation area in Bolivia's Gran Chaco. https://news. mongabay.com/2019/05/nembi-guasu-huge-newconservation-area-in-bolivias-gran-chaco/. Accessed on 15 September 2020.

Sierra Praeli, Y. 2019b. Bolivia y Paraguay se unen para proteger al guanaco. https://es.mongabay.com/2019/ 06/bolivia-paraguay-proteger-guanaco/. Accessed on 15 September 2020.

Smith, P., \& R.D. Owen. 2017. Calyptophractus retusus (Cingulata: Dasypodidae). Mammalian Species 49: 57-62. https://doi.org/10.1093/mspecies/sex005

Smith, P. \& S. D. Ríos. 2018. Distribution and status of Paraguayan Xenarthra: towards a better understanding. Edentata 19: 1-29. https://doi.org/10.2305/IUCN. CH.2018.Edentata-19-1.2.en

Ten, S., J. A. Díaz-Luque, U. Lombardo \& A. Montejo. 2016 APM Grandes Lagos Tectónicos de Exaltación, un aporte a su conocimiento. Informe Técnico. Consultoría, CIBIOMA - UAB, Beni, Bolivia. 79 pp.

UAGRM - Universidad Autónoma Gabriel René Moreno \& FAUNAGUA. 2017. Levantamiento de biodiversi- 
dad en la región de los Lagos del Rogaguado, sitio Ramsar cuenca Yata, en el complejo de humedales de los Llanos de Moxos-Beni, Bolivia. Informe Final, Proyecto OE 49. 70 pp.

Wallace, R. B. \& R. L.E. Painter. 2013. Observations on the diet of the giant armadillo (Priodontes maximus Kerr, 1792). Edentata 14: 85-86. https://doi. org/10.5537/020.014.0112

Wallace, R.B. \& Z.R. Porcel. 2010. Interrogantes taxonómicas y posibles adiciones para los mamíferos medianos y grandes de Bolivia. Pp. 831-850 in: Distribución, ecología y conservación de los mamíferos medianos y grandes de Bolivia (R.B. Wallace, H. Gómez, Z.R. Porcel \& D.I. Rumiz, eds.). Centro de Ecología Difusión Simón I. Patiño, Santa Cruz de la Sierra, Bolivia. 906 pp.
Wallace, R. B., H. Gómez, Z.R. Porcel \& D.I. Rumiz (eds.). 2010. Distribución, ecología y conservación de los mamíferos medianos y grandes de Bolivia. Centro de Ecología Difusión Simón I. Patiño, Santa Cruz de la Sierra, Bolivia. 906 pp.

Wallace, R.B., H. Lopez-Strauss, N. Mercado \& Z.R. Porcel. 2013. Base de datos sobre la distribución de los mamíferos medianos y grandes de Bolivia. DVD Interactivo. Wildlife Conservation Society, La Paz, Bolivia.

WCS - Wildlife Conservation Society. 2020. Valores de conservación en riesgo por la ocurrencia de focos de calor. Boletín No 1 . WCS - Bolivia, La Paz, Bolivia. $35 \mathrm{pp}$.

Received: 19 October 2021; Accepted: 9 December 2021 


\section{ANNEX 1}

Distribution of the species of armadillos in Bolivia (modified from Wallace et al., 2010, 2013) with new records since 2012. MEDIUM CONFIDENCE: tracks or low-quality photographs; HIGH CONFIDENCE: direct observation, specimen collected, or high-quality photographs. All records since 2012 had a high confidence level.
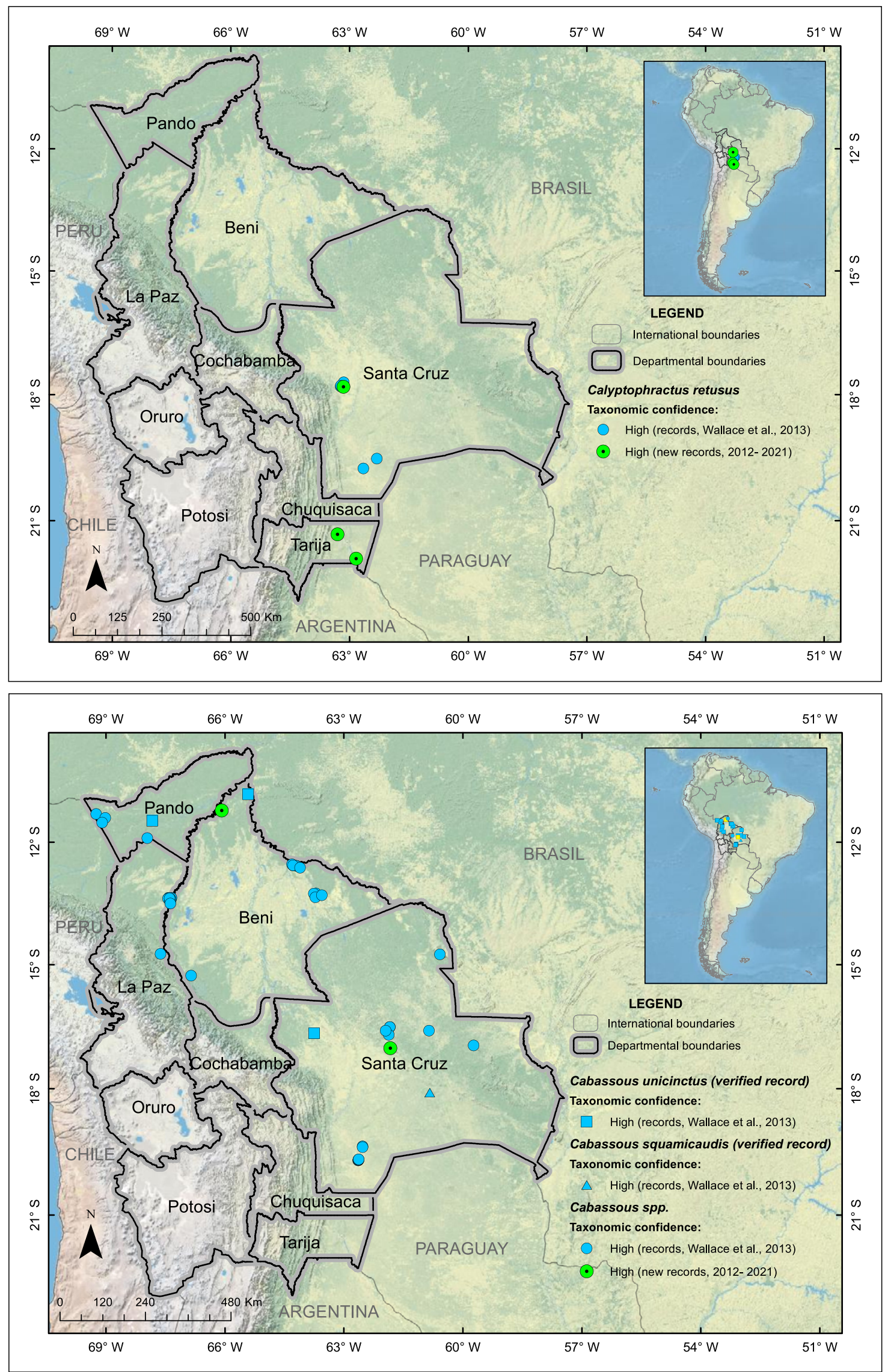

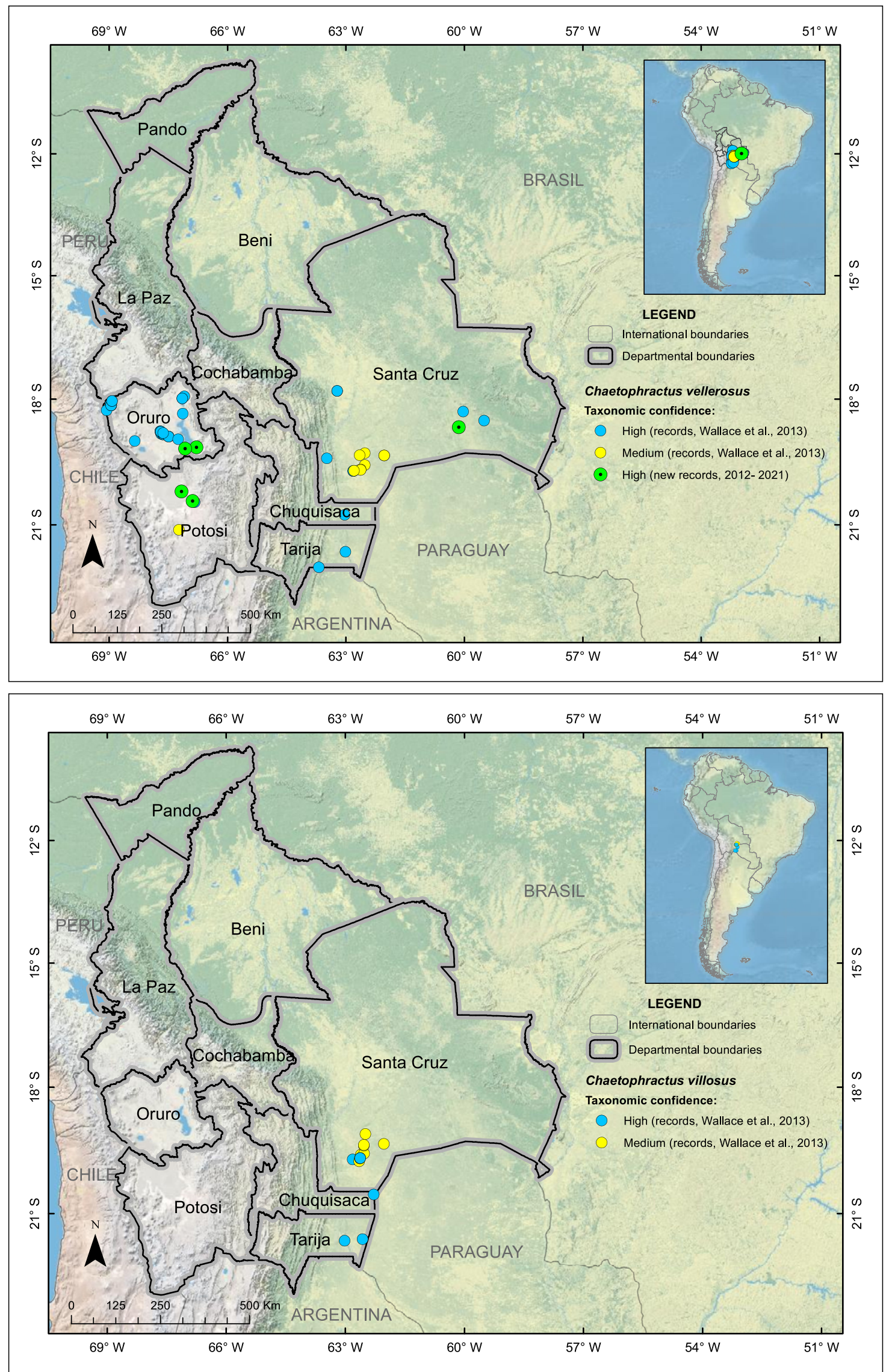

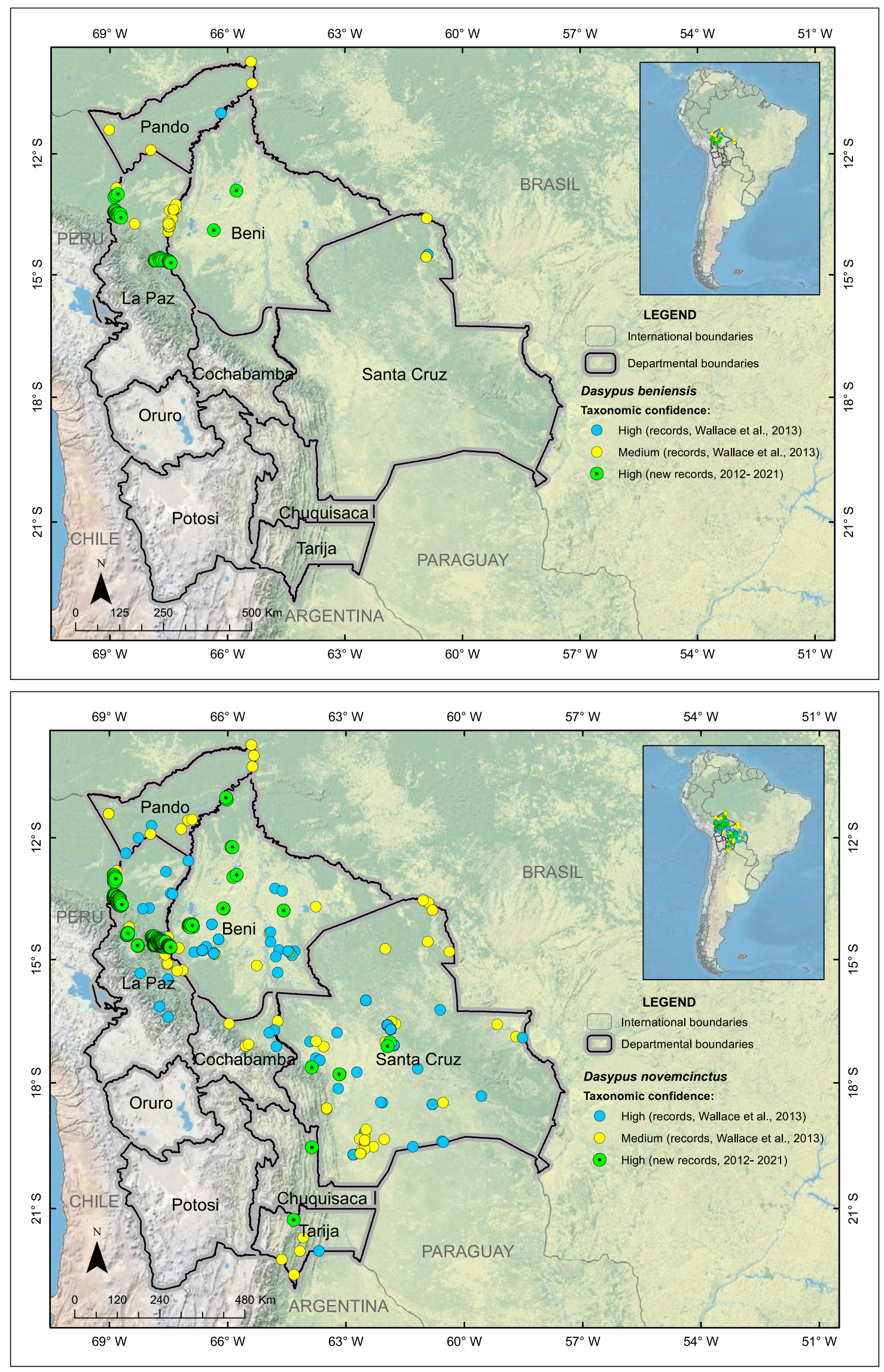

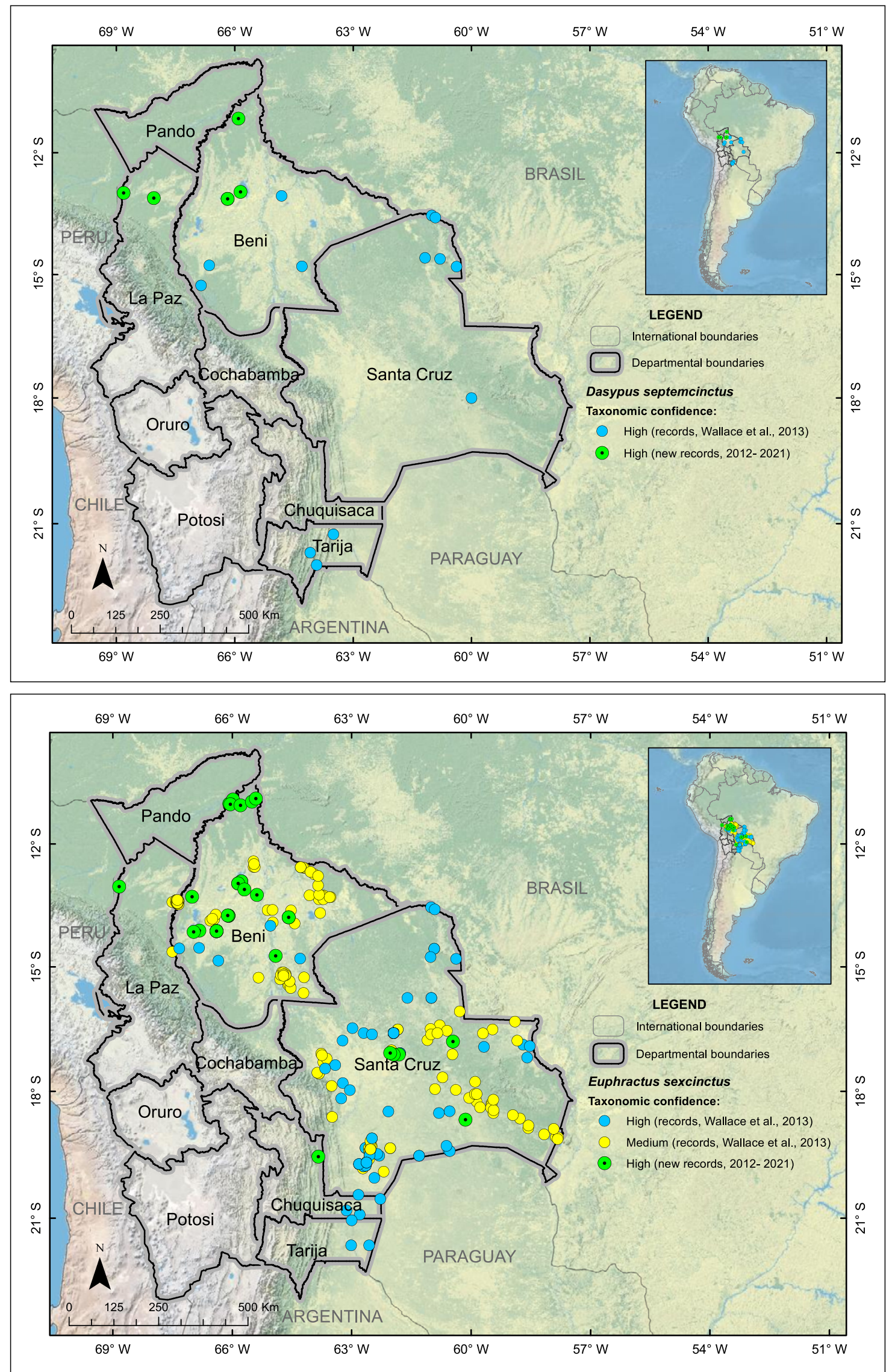

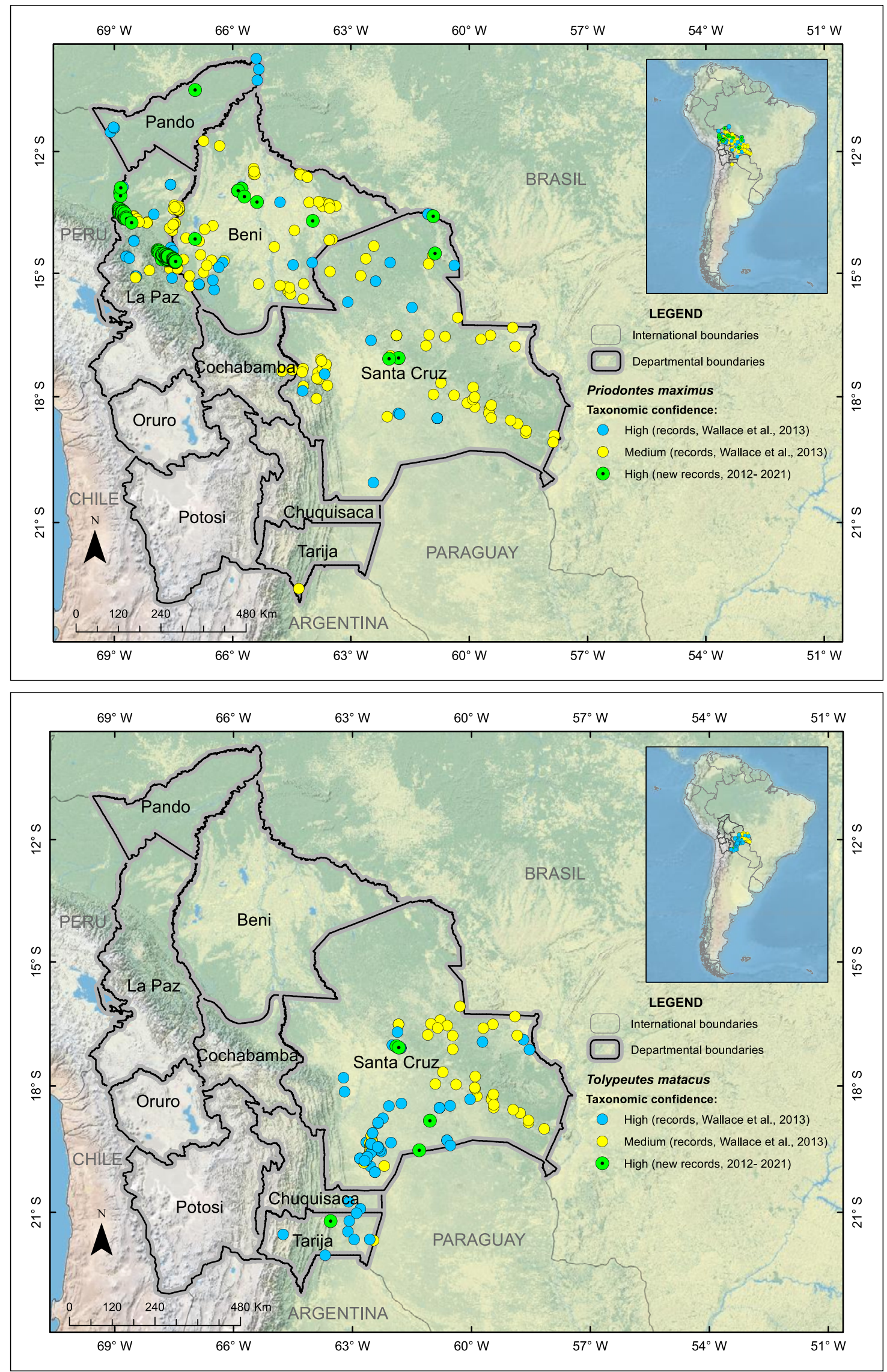


\section{ANNEX 2}

Distribution of the species of Pilosa in Bolivia (modified from Wallace et al., 2010, 2013), with new records since 2012. MEDIUM CONFIDENCE: tracks or low-quality photographs; HIGH CONFIDENCE: direct observation, specimen collected, or high-quality photographs. All records since 2012 had a high confidence level.
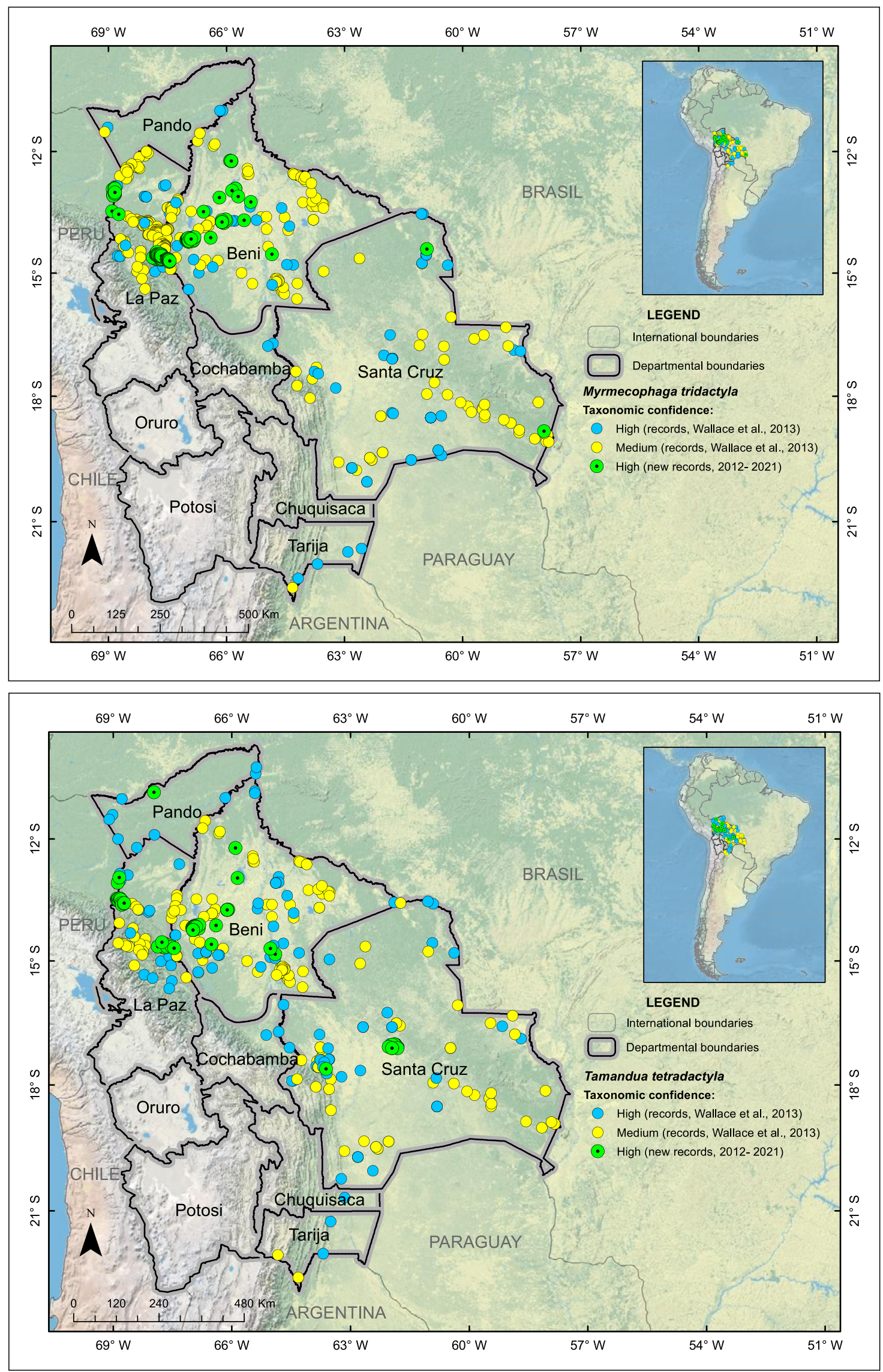

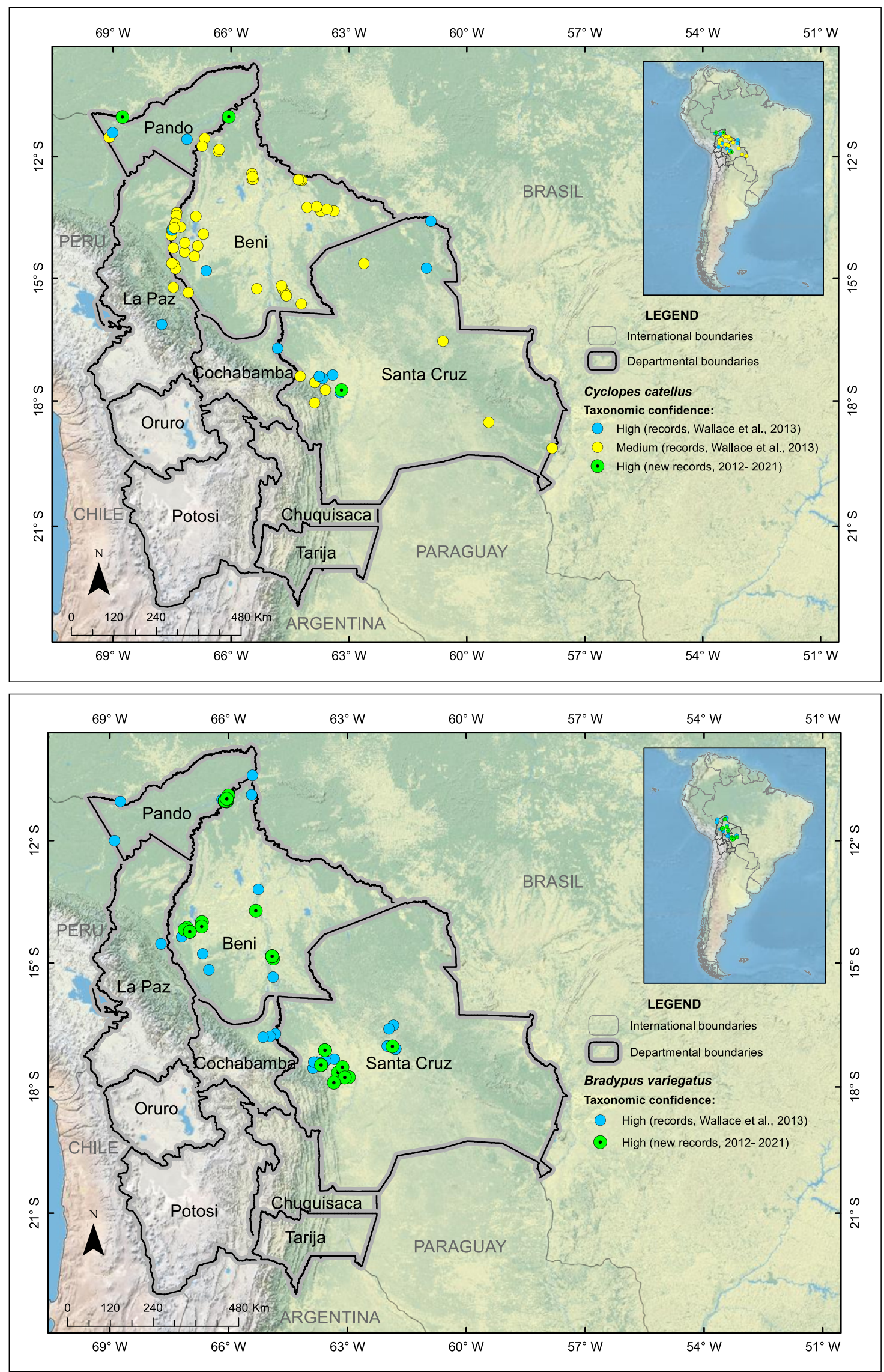


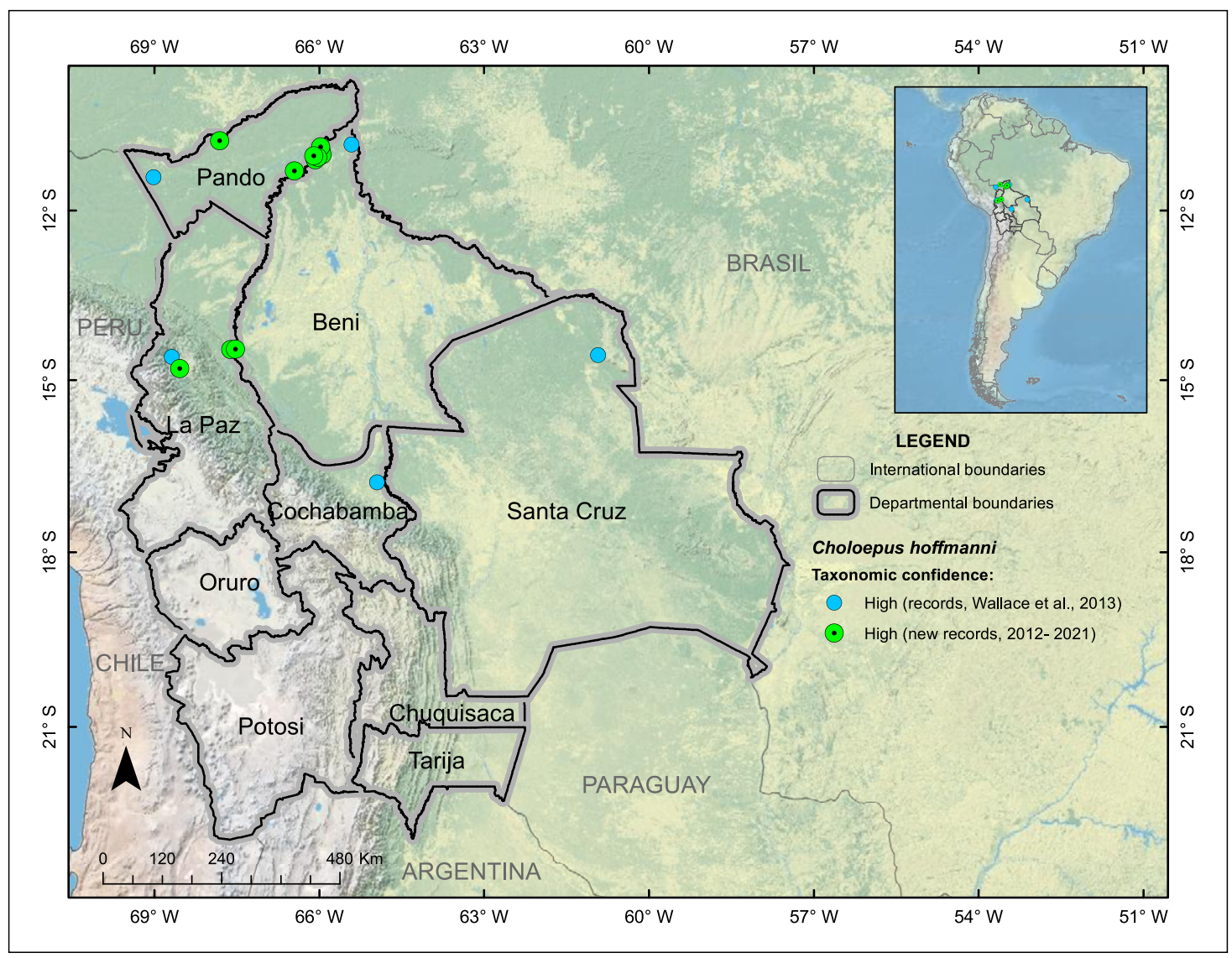




\title{
COMUNICAÇÃO BREVE
}

\section{Novo registro de Myrmecophaga tridactyla Linnaeus, 1758 (Mammalia: Xenarthra) no estado do Rio Grande do Sul, Brasil}

\author{
Karyne Fayes Sharara ${ }^{\mathrm{A}}$, Lucas Adriano Pachla ${ }^{\mathrm{B}, 1}$, \\ Marthoni Vinicius Massaro ${ }^{B}$ \& David Augusto Reynalte-Tataje ${ }^{C}$ \\ A Universidade Federal da Fronteira Sul, Curso de Ciências Biológicas, \\ Av. Jacob Reinaldo Haupenthal, 1580, 97900-000 Cerro Largo, RS, Brasil \\ B Universidade Federal da Fronteira Sul, Programa de Pós-Graduação em Ambientes e Tecnologias Sustentáveis, \\ Av. Jacob Reinaldo Haupenthal, 1580, 97900-000 Cerro Largo, RS, Brasil \\ 'Universidade Federal da Fronteira Sul, Docente permanente do Programa de Pós-graduação Stricto Sensu \\ em Ambientes e Tecnologias Sustentáveis da Universidade Federal da Fronteira Sul, \\ Av. Jacob Reinaldo Haupenthal, 1580, 97900-000 Cerro Largo, RS, Brasil \\ 1'Autor correspondente. E-mail: lucas.pachla@hotmail.com
}

\begin{abstract}
Resumo O tamanduá-bandeira Myrmecophaga tridactyla ocorre amplamente ao longo da região Neotropical. No entanto, é provável que esteja extinto em parte de sua distribuição original, levando esta espécie a ser classificada como Vulnerável à extinção (VU) pela IUCN. Um novo registro de ocorrência da espécie foi obtido no município de Santo Antônio das Missões, localizado na região de transição entre o bioma Mata Atlântica e Pampa, no estado do Rio Grande do Sul, Brasil. O registro de um indivíduo atropelado foi obtido durante o monitoramento de fauna realizado na rodovia BR-285 em novembro de 2019.
\end{abstract}

Palavras-chave: atropelamento, Bioma Pampa, conservação, tamanduá-bandeira

New record of Myrmecophaga tridactyla Linnaeus, 1758 (Mammalia: Xenarthra) in the State of Rio Grande do Sul, Brazil

Abstract The giant anteater Myrmecophaga tridactyla is widely distributed throughout the Neotropical region. However, it is likely to be extinct in part of its original distribution, leading this species to be classified as Vulnerable (VU) by the IUCN. A new occurrence record of a giant anteater was obtained in the municipality of Santo Antônio das Missões, located in the transition region of the Atlantic Forest and Pampa biomes in the state of Rio Grande do Sul, Brazil. The record of a giant anteater road-kill victim was made during a road monitoring carried out on BR-285 in November 2019.

Keywords: conservation, giant anteater, Pampa Biome, roadkill

Myrmecophaga tridactyla Linnaeus, 1758, chamado popularmente de tamanduá- bandeira, é uma espécie conhecida devido as suas peculiaridades morfológicas e comportamentais (Chebez, 1994; Eisenberg \& Redford, 2000; Chebez \& Cirignoli, 2008). Dentre suas distintas características vale ressaltar sua ecologia alimentar, altamente especializada no forrageamento de formigas e cupins (Mourão \& Medri, 2007). Esta especialização na dieta, associada à baixa taxa reprodutiva e grande tamanho corporal, torna a espécie mais sensível a impactos de origem antrópica, como atropelamentos e degradação de habitats (Ascensão et al., 2017; Giroux et al., 2021).

Segundo Pinto et al. (2018), a fragmentação de habitats e a mortalidade por atropelamento em estradas causam efeitos negativos nas populações de tamanduá-bandeira no Brasil, principalmente 


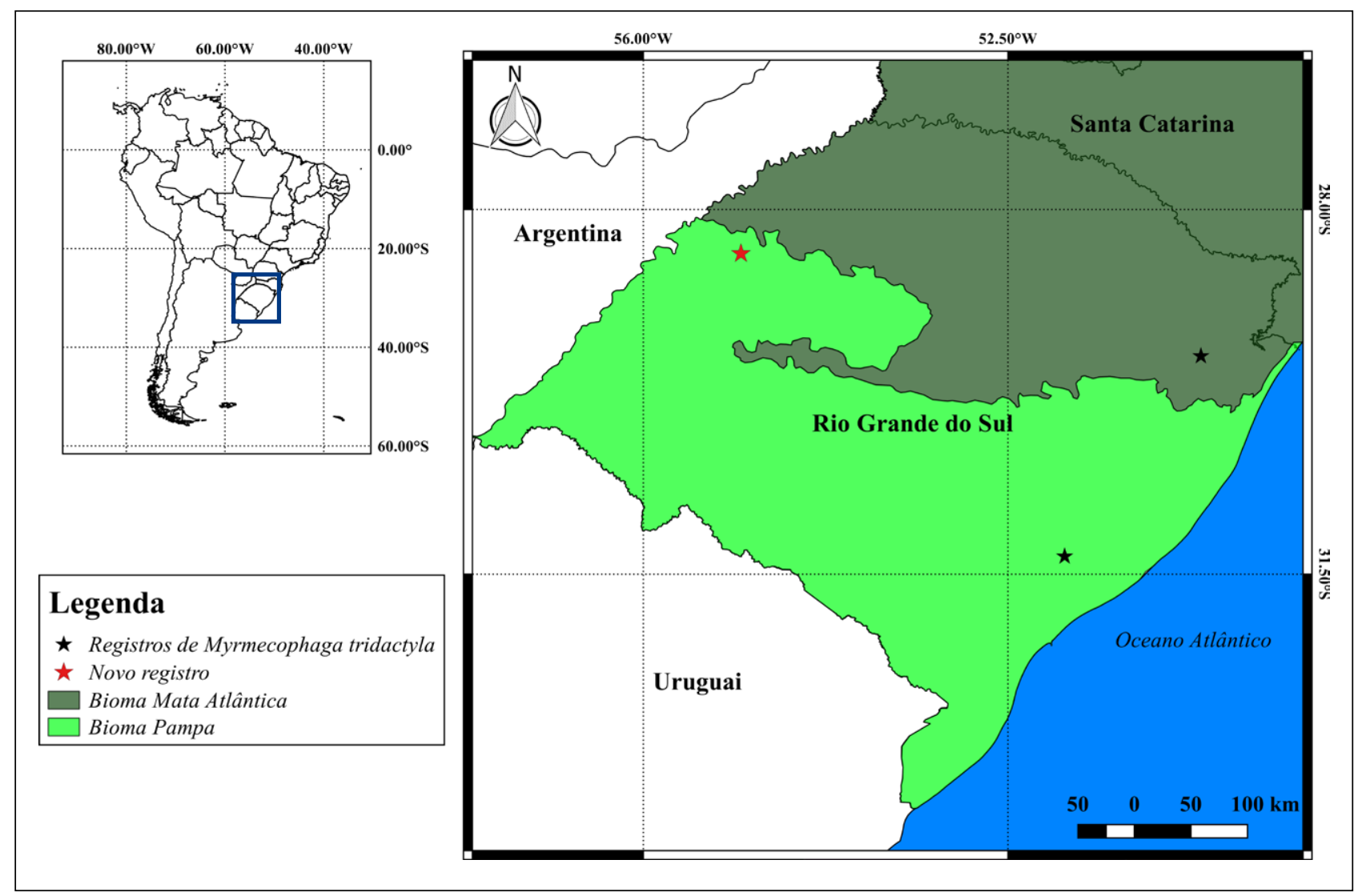

FIGURA 1. Registros de tamanduá-bandeira Myrmecophaga tridactyla Linnaeus, 1758 na região Sul do Brasil, segundo levantamento no site http://www.splink.org.br/.

na região Centro-Sul, considerada como uma zona crítica e suscetível a essas ameaças. Desbiez et al. (2020) demostraram com análises de viabilidade populacional que a mortalidade por atropelamentos é uma ameaça séria para a persistência em longo prazo. Dessa forma, a fragilidade em relação a atropelamentos e a perda de habitats influenciam diretamente no declínio populacional da espécie, inclusive, tornando-a rara em diversas regiões do país (MMA, 2008).

O tamanduá-bandeira ocorre em climas tropicais e subtropicais das Américas Central e do Sul e regiões áridas do Chaco, Cerrado e Caatinga (Wetzel, 1982; Gardner, 2008). Suas populações foram reduzidas em toda sua área de ocorrência levando a ser considerada Vulnerável (VU A2c) mundialmente, com extinções regionais, em especial na porção central e sul de sua distribuição (Miranda et al., 2014). A espécie é considerada extinta no Uruguai (Fallabrino \& Castiñeira, 2006; Ameneiros et al., 2015) e em perigo de extinção na Argentina (Di Blanco et al., 2019). Contudo, neste país, na Reserva Natural de Iberá, a espécie é alvo de um projeto de reabilitação e reintrodução, onde entre os anos de 2007 e 2012 foram reintroduzidos 18 indivíduos (Di Blanco et al., 2016). Além disso, a espécie possui apenas quatro registros próximos a região de fronteira entre Misiones (Argentina) e Rio Grande do
Sul (Brasil) entre os anos 2006 e 2012, sendo estes decorrentes de monitoramento participativo (Bauni et al., 2013).

No Brasil a espécie é categorizada como Vulnerável (VU) (ICMBio/MMA, 2018). Nos estados da região sul a situação é considerada crítica. No Paraná é classificada como Criticamente Ameaçada (CR) (Mikich \& Bérnils, 2004), em Santa Catarina não há informações sobre a espécie há mais de 30 anos (Cherem et al., 2004; Tortato \& Althoff, 2011) e segundo a avaliação mais recente do ICMBio, a espécie está Regionalmente Extinta (REx) (FATMA, 2011). No estado do Rio Grande do Sul, a espécie é considerada como Criticamente Ameaçada (CR) segundo a lista estadual de espécies ameaçadas de extinção (Rio Grande do Sul, 2014). Essa categoria foi indicada visto que existem apenas indicações imprecisas de sua ocorrência no estado (Silva, 1994; Freitas et al., 2009). Uma delas é um registro histórico, depositado no museu do município de São Lourenço do Sul (Vaz, 2003), e a outra é referente a um registro de indivíduo atropelado no ano de 1999, no município de São Francisco de Paula, sem registro fotográfico ou tombamento de material (Faria-Corrêa \& Villela, 2003; Fontana et al., 2003). Assim, a ausência de registros recentes contribui para a categorização de extinção regional da espécie (ICMBio/MMA, 2018). Aqui, documentamos 


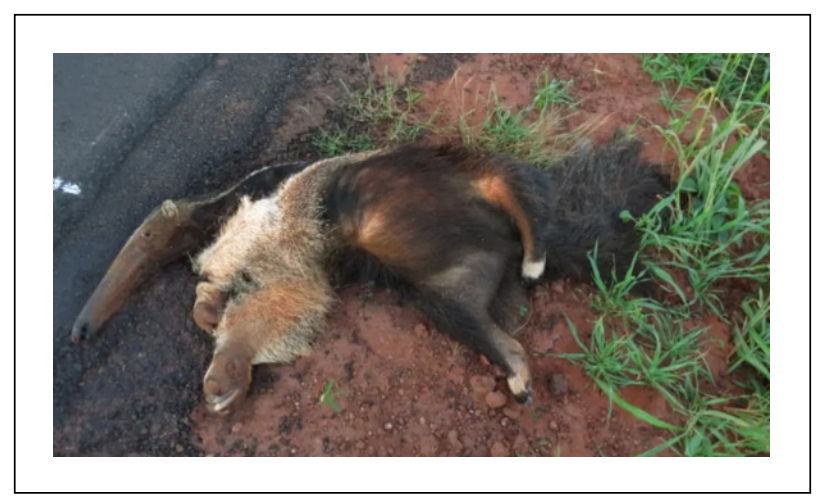

FIGURA 2. Registro realizado do tamanduá-bandeira Myrmecophaga tridactyla Linnaeus, 1758 na BR-285 ( $24^{\circ} 44^{\prime} 12^{\prime \prime}$, $50^{\circ} 14^{\prime} 13^{\prime \prime O}$ ) em Santo Antônio das Missões, Rio Grande do Sul, Brasil.

uma nova ocorrência da espécie no município de Santo Antônio das Missões, localizado na região noroeste do estado do Rio Grande do Sul.

O novo registro foi obtido entre as Fazendas Vista Alegre e Bela Vista (28 $\left.29^{\prime} 29^{\prime \prime} \mathrm{S}, 5^{\circ} 16^{\prime} 31^{\prime \prime O}\right)$ na faixa de acostamento da rodovia de via pavimentada simples BR-285, no município de Santo Antônio das Missões (FIG. 1). A região de área aberta é caracterizada por vegetação típica do Pampa, com presença de gramíneas, plantas rasteiras, arbustos e árvores de pequeno porte, além de fragmentos florestais isolados. A borda da rodovia, no acostamento do local do registro, possuía vegetação densa em torno de 40 a $70 \mathrm{~cm}$. A coleta foi realizada em 21 de novembro de 2019, durante um estudo de monitoramento de fauna atropelada realizado pelo Laboratório de Ecologia de Campo da Universidade Fronteira Sul-Campus Cerro Largo. O indivíduo, já sem vida e vítima de atropelamento, foi identificado somente na triagem do material fotográfico, não sendo tombada a sua carcaça (FIG. 2).

Os registros mais próximos deste local estão a cerca de $90 \mathrm{~km}$ de distância e foram feitos na Argentina entre os anos de 2006 e 2012 (Bauni et al., 2013). Nesse sentido, pode-se considerar que este indivíduo seja potencialmente um dispersor. Contudo, ressalta-se que próximo ao trecho do registro o rio Uruguai possui uma largura aproximada de $1250 \mathrm{~m}$ (Massaro et al., 2019), podendo agir como barreira física para esta espécie. Ainda, a região do registro está inserida no bioma Pampa, caracterizado por vastas planícies, vegetação campestres, e pelo clima mesotérmico, subtropical com verões quentes sem seca definida e invernos rigorosos (Köppen, 1936; Alvares et al., 2013). Estas características estão associadas ao uso de paisagens em mosaico vegetacional (Giroux et al., 2021) com temperaturas baixas, que modulam o período diurno como o de atividade.
Uma das principais ameaças para a conservação de $M$. tridactyla é a perda e degradação de habitats (Miranda et al., 2014). O Pampa teve uma perda de $21 \%$ da cobertura remanescente de vegetação nativa entre os anos de 1985 a 2019 (Braga, 2009; Miranda et al., 2014; Projeto MapBiomas, 2020). Considerando essa degradação através da expansão das fronteiras agrícolas com o grande avanço do cultivo de soja, plantio de espécies florestais exóticas, urbanização e caça predatória (Bilenca \& Miñarro, 2004), juntamente com o baixo número de registros, existe a possibilidade da espécie estar extinta no estado Rio Grande do Sul, devido à redução de habitats adequados para a sua manutenção. Entretanto, levantamos a possibilidade da existência de uma pequena população ou até mesmo de movimentação de indivíduos provenientes da $\mathrm{Ar}$ gentina, considerando a proximidade de registros. Assim, destacamos a extrema necessidade de mais levantamentos focados na busca por essa espécie no estado, principalmente na região do registro.

\section{REFERÊNCIAS}

Alvares, C.A., J.L. Stape, P.C. Sentelhas, J.L. De Moraes Gonçalves \& G. Sparovek. 2013. Köppen's climate classification map for Brazil. Meteorologische Zeitschrift 22: 711-728. https://doi.org/10.1127/09412948/2013/0507

Ameneiros, A., et al. 2015. Distribución del Magnaorden Xenarthra en Uruguay en base a registros bibliográficos y de colecciones. Edentata 16: 21-27.

Ascensão, F., A. L.J. Desbiez, E.P. Medici \& A. Bager. 2017. Spatial patterns of road mortality of medium-large mammals in Mato Grosso do Sul, Brazil. Wildlife Research 44: 135-146. https://doi.org/10.1071/WR16108

Bauni, V., V. Capmourteres, M.A. Homberg \& G.A. Zuleta. 2013. Distribution and status of the extant xenarthrans (Mammalia: Xenarthra) in the Southern Cone Mesopotamian savanna, Argentina. Edentata 14: 35-50. https://doi.org/10.5537/020.014.0105

Bilenca, D. \& F. Miñarro. 2004. Identificación de Áreas Valiosas de Pastizal (AVPs) en las pampas y campos de Argentina, Uruguay y sur de Brasil. Fundación Vida Silvestre Argentina, Buenos Aires. 353 pp.

Braga, F.G. 2009. Plano de conservação para Tamanduá -Bandeira (Myrmecophaga tridactyla). Pp. 14-30 in: Planos de conservação para espécies de mamíferos ameaçados (I.A. do Paraná, ed.) IAP/Projeto Paraná Bidiversidade, Curitiba.

Braga, F. G., R.E.F. Santos \& A.C. Batista. 2010. Marking behavior of the giant anteater Myrmecophaga tridactyla (Mammalia: Myrmecophagidae) in southern Brazil. Zoologia 27: 7-12. https://doi.org/10.1590/ S1984-46702010000100002

Chebez, J.C. 1994. Especies argentinas en peligro. Pp. 184189 in: Los que se van: fauna argentina amenazada (J.C. Chebez, ed.). Albatros, Buenos Aires. 
Chebez, J. C. \& S. Cirignoli. 2008. Yurumí. Pp. 31-40 in: Los que se van: fauna argentina amenazada (J.C. Chebez, ed.). Albatros, Buenos Aires.

Cherem, J.J., P.C. Simões-Lopes, S. Althoff \& M.E. Graipel. 2004. Lista dos mamíferos do estado de Santa Catarina, sul do Brasil. Mastozoología Neotropical, 11: 151-184.

Desbiez, A.L.J., A. Bertassoni \& K. Traylor-Holzer. 2020. Population viability analysis as a tool for giant anteater conservation. Perspectives in Ecology and Conservation 18: 124-131. https://doi.org/10.1016/j.pecon. 2020.04.004

Di Blanco, Y.E., K.L. Spørring \& M.S. Di Bitetti. 2016. Daily activity pattern of reintroduced giant anteaters (Myrmecophaga tridactyla): Effects of seasonality and experience. Mammalia 81: 11-21. https://doi. org/10.1515/mammalia-2015-0088

Di Blanco, Y.E., D. Varela \& A.M. Abba. (2019). Myrmecophaga tridactyla. In: Categorización 2019 de los mamíferos de Argentina según su riesgo de extinción. Lista Roja de los mamíferos de Argentina (SAyDS SAREM, eds.). http://doi.org/10.31687/SaremLR.19.032

Eisenberg, J.F. \& K.H. Redford. 2000. Mammals of the Neotropics, Volume 3. The central Neotropics: Ecuador, Peru, Bolivia, Brazil. University of Chicago Press, Chicago.

Fallabrino, A. \& E. Castiñeira. 2006. Situación de los Edentados en Uruguay. Edentata 7: 1-9. https://doi.org/ 10.1896/1413-4411.7.1.1

Faria-Corrêa, M.A. \& F.S. Villela. 2003. Projeto tamanduás do Rio Grande do Sul: distribuição atual, ocorrência e ameaças a conservação do tamanduá-mirim (Tamandua tetradactyla) e do tamanduá-bandeira (Myrmecophaga tridactyla) (Xenarthra: Myrmecophagidae) no Estado do Rio Grande do Sul. II Congresso Brasileiro de Mastozoologia, Belo Horizonte.

FATMA - Fundação de Meio Ambiente. 2011. Lista das espécies da fauna ameaçada de extinção em Santa Catarina: Relatório Técnico Final. https://www.ima. sc.gov.br/index.php/downloads/biodiversidade/ fauna/2432-relatorio-tecnico-final-lista-de-especies -ameacadas-de-extincao-em-sc. Acesso em 12 de abril de 2021.

Fontana, C.S., G. A. Bencke \& R. E. Reis. 2003. Livro vermelho da fauna ameaçada de extinção do Rio Grande do Sul. Edipuc, Porto Alegre. 632 pp.

Freitas, T.R.O., G.L. Gonçalves, A.S. Cunha, J.F. Stolz \& J.R. Marinho. 2009. Mamíferos. Pp. 209-223 in: Biodiversidade dos campos do planalto das araucárias (I. I. Boldrini, ed.). Ministério do Meio Ambiente, Brasília.

Gardner, A.L. 2008. Mammals of South America, Volume 1: Marsupials, xenarthrans, shrews, and bats. University of Chicago Press, Chicago. https://doi. org/10.7208/chicago/9780226282428.001.0001

Giroux, A., et al. 2021. The role of environmental temperature on movement patterns of giant anteaters. Integrative Zoology. Epub ahead of print. https:// doi.org/10.1111/1749-4877.12539
ICMBio / MMA - Instituto Chico Mendes de Conservação da Biodiversidade e Ministério do Medio Ambiente. 2018. Livro Vermelho da fauna brasileira ameaçada de extinção. ICMBio/MMA, Brasília. 495 pp.

Köppen, W. 1936. Das geographische System der Klimate. Pp. 1-44 in: Handbuch der Klimatologie (W. Köppen \& R. Geiger, eds.). Gebrüder Bornträger, Berlin.

Massaro, M.V., L.A. Pachla, R. Bastian, F.M. Pelicice \& D.A. Reynalte-Tataje. 2019. Seasonal and longitudinal variation in fish assemblage structure along an unregulated stretch of the Middle Uruguay River. Neotropical Ichthyology 17: e190043. https://doi. org/10.1590/1982-0224-20190043

Mikich, S.B. \& R.S. Bérnils. 2004. Livro vermelho da fauna ameaçada no Estado do Paraná (M.G.P. Tossulino \& M.D. Nogarolli, eds.). Instituto Ambiental do Paraná, Curitiba.

Miranda, F. R., et al. 2014. Avaliação do risco de extinção de Myrmecophaga tridactyla Linnaeus, 1758 no Brasil. Pp. 89-106 in: Avaliação do risco de extinção dos xenartros brasileiros (ICMBio, ed.). ICMBio, Brasília.

Mourão, G. \& I. M. Medri. 2007. Activity of a specialized insectivorous mammal (Myrmecophaga tridactyla) in the Pantanal of Brazil. Journal of Zoology 271: 187-192. https://doi.org/10.1111/j.1469-7998.2006.00198.x

Pinto, F.A.S., A. Bager, A.P. Clevenger \& C. Grilo. 2018. Giant anteater (Myrmecophaga tridactyla) conservation in Brazil: Analysing the relative effects of fragmentation and mortality due to roads. Biological Conservation 228: 148-157. https://doi.org/10. 1016/j.biocon.2018.10.023

Rio Grande Do Sul. 2014. Decreto Estadual no 51.797, de 08 setembro de 2014. Declara as espécies da fauna silvestre ameaçadas de extinção no Rio Grande do Sul. Diário Oficial 2014: 2-12.

Silva, F. 1994. Mamíferos silvestres do Rio Grande do Sul. Fundação Zoobotânica, Porto Alegre.

Tortato, F.R. \& S.L. Althoff. 2011. Mammalia, Myrmecophagidae, Myrmecophaga tridactyla (Linnaeus, 1758) and Cervidae, Ozotoceros bezoarticus (Linnaeus, 1758): Contribution to the knowledge of the historical distribution in Santa Catarina, southern Brazil. Check List 7: 146-148. https://doi.org/10. 15560/7.2.146

Vaz, S.M. 2003. Lista de localidades de captura de xenarthros sob ameaça de extinção no Brasil. Edentata 6: 4-5.

Wetzel, R.M. 1982. Systematics, distribution, ecology, and conservation of South American Edentates. Pp. 345-375 in: Mammalian biology in South America (M. Mares \& H.H. Genoways, eds.). Special Publication Series, Pymatuning Laboratory of Ecology, University of Pittsburgh, Pittsburgh.

Recebido em: 10 de setembro de 2020; aceito em: 14 de julho de 2021 


\title{
SHORT COMMUNICATION
}

\section{First records of the seven-banded armadillo (Dasypus septemcinctus) and the six-banded armadillo (Euphractus sexcinctus) in northwestern Bolivia}

\author{
Guido Marcos Ayala ${ }^{\mathrm{A}, \mathrm{C}, 1}$, María Estela Viscarra ${ }^{\mathrm{A}}$ \\ \& Robert Benedict WALLACE ${ }^{\mathrm{A}, \mathrm{C}}$ \\ A Wildlife Conservation Society, Greater Madidi-Tambopata Landscape Conservation Program, \\ \#340 Calle Gabino Villanueva, Calacoto, La Paz, Bolivia \\ ${ }^{B}$ Wildlife Conservation Society, $185^{\text {th }}$ and Southern Boulevard, Bronx, NY 10460, U.S.A. \\ ' Department of Biology \& Centre for Environmental and Marine Studies (CESAM), University of Aveiro, \\ 3810-13 Aveiro, Portugal \\ ${ }^{1}$ Corresponding author. E-mail: gayala@wcs.org
}

\begin{abstract}
Armadillos are poorly studied in Bolivia and there is little information on their ecology, natural history, and distribution in the country. Here we increase the knowledge of the geographic distribution of two species of armadillos, Dasypus septemcinctus and Euphractus sexcinctus, with new camera trap-derived distribution records in northwestern Bolivia, in the department of La Paz. These new records are the westernmost records of the geographic distribution of both armadillos and are also new records for Madidi National Park and Natural Area of Integrated Management.
\end{abstract}

Keywords: armadillos, camera traps, Madidi National Park and Natural Area of Integrated Management, new records

Primeros registros del armadillo de siete bandas (Dasypus septemcinctus) y el armadillo de seis bandas (Euphractus sexcinctus) en el noroeste de Bolivia

Resumen Los armadillos están poco estudiados en Bolivia y hay escasa información sobre su ecología, historia natural y distribución en el país. Aquí aumentamos el conocimiento de la distribución geográfica de dos especies de armadillos, Dasypus septemcinctus y Euphractus sexcinctus, con nuevos registros de distribución obtenidos con cámaras trampa en el noroeste de Bolivia, en el departamento de La Paz. Estos nuevos datos son los registros más occidentales de la distribución geográfica de ambos armadillos y también son nuevos registros para el Parque Nacional y Área Natural de Manejo Integrado Madidi.

Palabras clave: armadillos, cámaras trampa, nuevos registros, Parque Nacional y Área Natural de Manejo Integrado Madidi

Armadillos belong to the order Cingulata and are characterized by having a dorsal carapace formed by juxtaposed plates arranged in transverse rows, with tails and short limbs. Armadillos are distributed from the central United States to the southern tip of Argentina (Wetzel, 1985; Eisenberg \& Redford, 1999; Noss et al., 2010). Many armadillo species are threatened by habitat loss and degradation, as well as overhunting (Superina \& Abba, 2020).

Bolivia is one of the countries with the greatest richness of armadillos, with at least 11 species distributed in different habitats (Aguirre et al., 2019). In northern Bolivia, six species are present, three 
of the genus Dasypus and one species each of the genera Cabassous, Euphractus, and Priodontes (Noss et al., 2010). The seven-banded armadillo (Dasypus septemcinctus Linnaeus, 1758) and the six-banded armadillo (Euphractus sexcinctus Linnaeus, 1758) are species with few distributional records in northern Bolivia, as compared to D. novemcinctus and D. beniensis. Dasypus septemcinctus is the smallest species of the genus (total head-body length: $380-525 \mathrm{~mm}$ ), with six to seven mobile bands on its carapace and a very short tail (Noss et al., 2010; Superina \& Abba, 2018). It has the southernmost distribution of the genus, occurring in Brazil, Paraguay, Bolivia, Uruguay, and Argentina. It is present in savanna, grassland, forest, and disturbed habitats (Noss et al., 2010; Feijó, 2020). Until 2010, in Bolivia there were only 22 confirmed records of this species in the Beni, Santa Cruz, and Tarija departments, at altitudes between 100 and $800 \mathrm{~m}$ asl (Noss et al., 2010; Wallace et al., 2013) (FIG. 1).

The six-banded armadillo (E. sexcinctus) has a chunkier appearance, with 6-7 mobile bands on the carapace, a total head-body length of $355-540 \mathrm{~mm}$, and a distinctive triangular-shaped head (Noss et al., 2010; Superina \& Abba 2018). It is distributed from southern Suriname to northern Argentina, in savanna, scrub, and dry and semi-deciduous forest habitats (Noss et al., 2010). In Bolivia, until 2010, there were a total of 276 records in the departments of Beni, Santa Cruz, Chuquisaca, Tarija, and La Paz, in an altitudinal range from 100 to $894 \mathrm{~m}$ asl (Noss et al., 2010; Wallace et al., 2013). In 2016 two more records of the six-banded armadillo were added by camera traps in the Beni Department (Ayala et al., 2017) (FIG. 1).

During 2017, as part of the scientific expedition Identidad Madidi (Identidad Madidi \& SERNAP, 2020), a research campaign was conducted to record the biodiversity of the middle part of the Heath river, including efforts to sample the natural pampas grasslands in the Pampas del Heath. This work reports new records of two armadillos, D. septemcinctus and E. sexcinctus, in northwestern Bolivia and updates their national and global distribution.

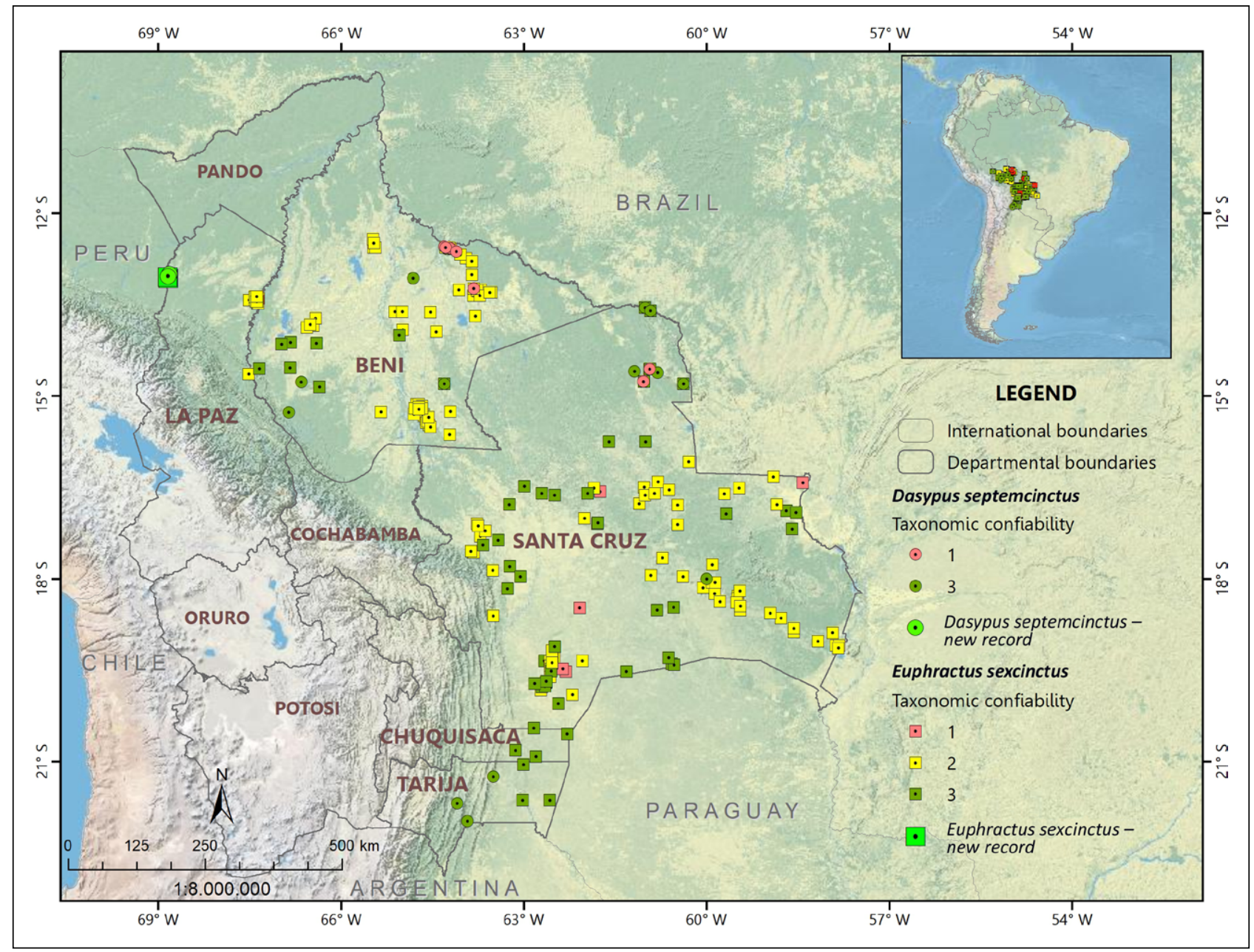

FIGURE 1. Updated geographic distribution of the six-banded armadillo (Euphractus sexcinctus) and the seven-banded armadillo (Dasypus septemcinctus) with new records in northwestern Bolivia and previously published records (Wallace et al., 2013; Ayala

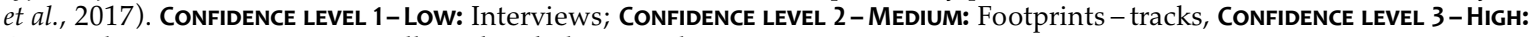
Direct observation, specimen collected and photographs. 


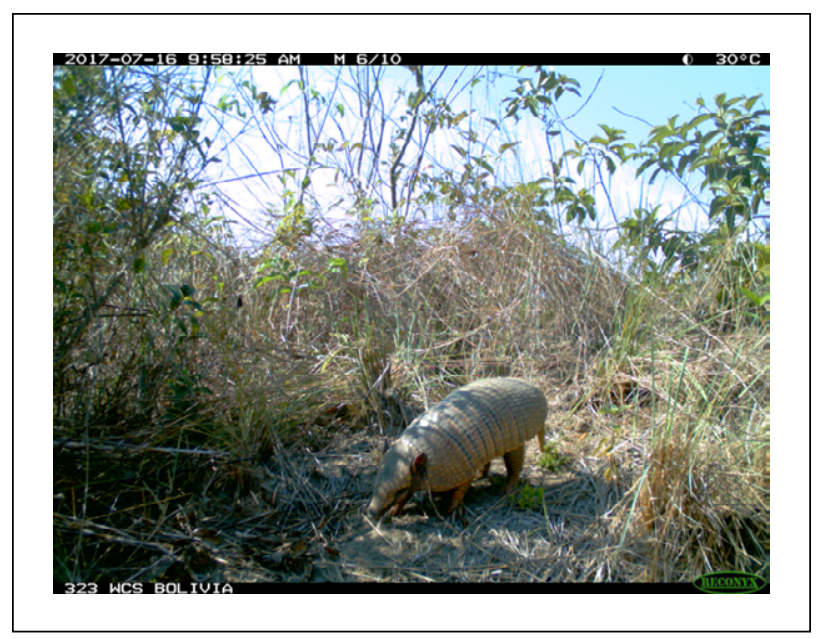

FIGURE 2. Camera trap record of the six-banded armadillo (Euphractus sexcinctus) in the Pampas del Heath, Madidi National Park and Natural Area of Integrated Management, Bolivia.

The study was conducted in the Heath basin in the Madidi National Park and Natural Area of Integrated Management (Madidi NP NAIM). The site has a slight altitudinal gradient of 194 to $222 \mathrm{~m}$ asl. The main camp was located in Puerto Moscoso $\left(13^{\circ} 0^{\prime} 59.33^{\prime \prime} \mathrm{S}, 68^{\circ} 51^{\prime} 7.14^{\prime \prime} \mathrm{W}\right)$, a three-day boat ride from Puerto Chive. The survey was conducted from 20 June to 17 July 2017.

In general, the climate is warm, humid and tropical, with a marked dry season between May and October, and a total annual precipitation of approximately $2000 \mathrm{~mm}$. The average temperature is between 24 and $26^{\circ} \mathrm{C}$ (Montambault, 2002). The study area presents flooded forest, terra firme forest, pampas transition forest (chaparral or scrub), forest islands, gallery forest, and palm groves associated with savannas and swamps. The Pampas del Heath are a unique vegetation formation associated with fire dynamics, drainage and micro-relief (Montambault, 2002; Identidad Madidi \& SERNAP, 2020). The Pampas del Heath are little explored, especially in the flooded parts.

Two methodologies were employed to record medium and large-sized mammals in the Pampas del Heath: camera trap surveys and line transects. A total of 71 camera trap stations were placed (savanna $\mathrm{n}=15$; forest $\mathrm{n}=56$ ), with a distance between stations of $0.7-2 \mathrm{~km}$, collectively covering an effective area of $152.58 \mathrm{~km}^{2}$ in forest and $31.58 \mathrm{~km}^{2}$ in savanna habitats (savanna edge, forest island, and savanna scrub habitats). All cameras were programmed to operate 24 hours a day, taking 10 photos for each event at 1 -minute intervals. All stations were active for 25 effective days.

A $4 \mathrm{~km}$ long path was enabled in the pampas to apply the line transect methodology. The routes were carried out during daylight hours starting at 06:30 h, at a rate of approximately $1 \mathrm{~km} /$ hour.
Camera trapping efforts in the Pampas del Heath yielded a sampling effort of 373.44 trap nights in savanna and 1,505.96 trap nights in forest habitats. Line transects amounted to a total distance of $48 \mathrm{~km}$.

Euphractus sexcinctus was recorded with camera traps (FIG. 2) at two stations in savanna-scrub at distances of 51 and $140 \mathrm{~m}$ from the forest edge. Dasypus septemcinctus was recorded with camera traps (FIG. 3) in the natural savanna at $870 \mathrm{~m}$ distance from the forest edge and in line transects at $550 \mathrm{~m}$ from the edge (TABLE 1).

The records of both armadillos in the Pampas del Heath are the first for the Madidi national protected area, and the first of $D$. septemcinctus for the La Paz Department. These observations are also the westernmost records of the overall distribution of both species.

Both species of armadillos presented low occurrence of records, suggesting that they are species of relatively low abundance. Camera trapping with 25 days of effective sampling recorded E. sexcinctus twice and D. septemcinctus once, and in 23 days of line transect sampling $D$. septemcinctus was registered once. Three other armadillo species were also registered during fieldwork: D. novemcinctus $(\mathrm{n}=231$ photographs; $\mathrm{n}=18$ independent events), D. beniensis ( $\mathrm{n}=184$ photographs; $\mathrm{n}=11$ independent events), and Priodontes maximus ( $\mathrm{n}=24$ photographs; $\mathrm{n}=3$ independent events) (Ayala \& Viscarra, 2018).

The closest records of E. sexcinctus with high taxonomic reliability (camera trap records) to the new records reported in this study are in General José Ballivian Province, Beni Department (Ayala et al., 2017), at a distance of $235 \mathrm{~km}$ (FIG. 1). The closest record of $D$. septemcinctus with high taxonomic reliability (specimen) to those reported in this study is found in the San Borja municipality, General José Ballivian Province, Beni Department (Wallace et al., 2013), at a distance of $307 \mathrm{~km}$ (FIG. 1). The records of both species of armadillos in the Pampas del Heath are the first for northwestern Bolivia, as well as the westernmost records of their distribution in South America. Therefore, this finding expands the known distribution of both species. It is also likely that their distribution extends throughout the Pampas del Heath (approximately $587 \mathrm{~km}^{2}$ ), including the small piece of Pampas on the Peruvian side of the Heath river. Given the proximity of these records to the Peruvian portion of the Pampas del Heath grasslands, surveys in Peru are urgently required as both would be new species for the country.

We recommend further studies focused on estimating the population status of both armadillos in this area. Globally, both species are currently classified as Least Concern (LC) according to the IUCN 


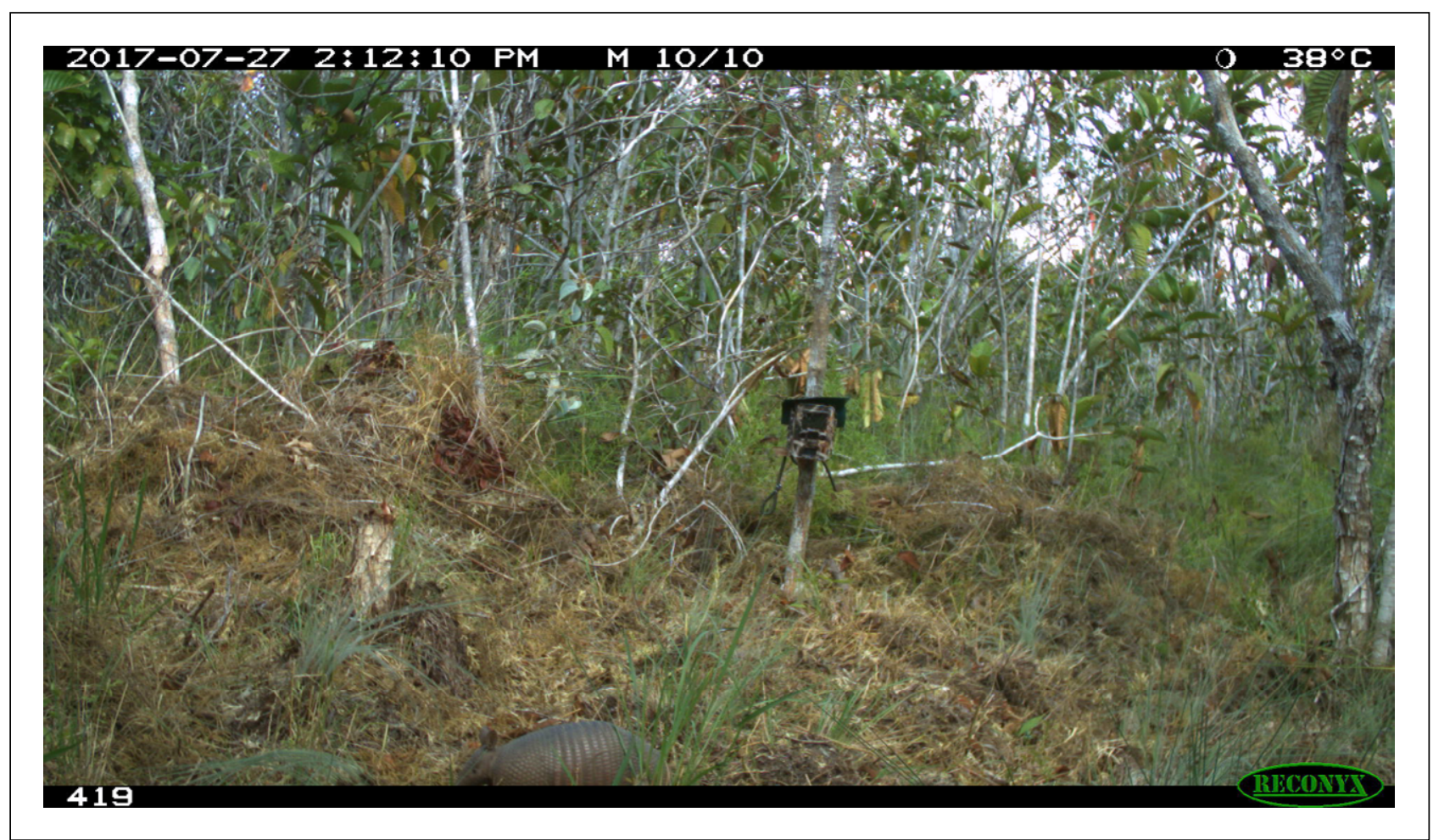

FIGURE 3. Camera trap record of the seven-banded armadillo (Dasypus septemcinctus) in the Pampas del Heath, Madidi National Park and Natural Area of Integrated Management, Bolivia.

(Abba et al., 2014; Anacleto et al., 2014) and Data Deficient (DD) at the national scale (Tarifa \& Aguirre, 2009).

Finally, this study is one of the fruits of the scientific expedition Identidad Madidi, which increased knowledge about the conservation importance of the Pampas del Heath. Representing the last remnants of natural savannas in the country, the Pampas del Heath are home to a great biological diversity, and as studies increase, more of their secrets and conservation values will be revealed.

\section{ACKNOWLEDGEMENTS}

The Greater Madidi-Tambopata Landscape Conservation Program of the Wildlife Conservation Society (WCS) is financed by the Gordon and Betty
Moore Foundation (GBMF) and WCS. Specific financial support for camera trapping was provided by GBMF and WCS. We are grateful to the Bolivian Protected Area Service (SERNAP), the Bolivian Biodiversity and Protected Area Directorate (DGBAP), the Madidi protected area administrations, and guards who supported our activities. We also thank Herminio Ticona, Carlos Aguilera, Edson Gonzales, Juan Eduardo Gonzales, Esteban Canare, and Fortunato Espinoza for assisting camera trapping efforts. A special thanks to the communities Las Mercedes and Puerto Perez who unconditionally supported us for the development of all the investigations in the field; without their help and permission it would not have been easy to achieve the objectives of this investigation. A special thanks to Ariel Reinaga for the support provided in the elaboration of maps.

TABLE 1. Records of Dasypus septemcinctus and Euphractus sexcinctus with camera traps and line transects in the Pampas del Heath, Madidi National Park and Natural Area of Integrated Management, Bolivia. CT: camera traps, T: transects.

\begin{tabular}{cccccccc}
\hline Species & Date & Time & Coordinates & Altitude (m asl) & Habitat & \multicolumn{2}{c}{ Type of record } \\
\hline D. septemcinctus & $27 / 07 / 2017$ & $14: 12$ & $12^{\circ} 59^{\prime} 56.48^{\prime \prime} \mathrm{S}$ & $68^{\circ} 48^{\prime} 51.34^{\prime \prime} \mathrm{W}$ & 204 & Forest inland edge & $\mathrm{CT}$ \\
& $09 / 07 / 2017$ & $11: 24$ & $13^{\circ} 2^{\prime} 19.48^{\prime \prime S}$ & $68^{\circ} 50^{\prime} 19.42^{\prime \prime} \mathrm{W}$ & 203 & Pampas & $\mathrm{T}$ \\
\hline E. sexcinctus & $02 / 07 / 2017$ & $18: 15$ & $13^{\circ} 3^{\prime} 52.23^{\prime \prime} \mathrm{S}$, & $68^{\circ} 50^{\prime} 15.24^{\prime \prime} \mathrm{W}$ & 205 & Pampas scrub & $\mathrm{CT}$ \\
& $25 / 07 / 2017$ & $14: 38$ & $13^{\circ} 2^{\prime} 39.87^{\prime \prime} \mathrm{S}$ & $68^{\circ} 50^{\prime} 31.36^{\prime \prime} \mathrm{W}$ & 206 & Pampas scrub $\mathrm{CT}$ \\
\hline
\end{tabular}




\section{REFERENCES}

Abba, A.M., E. Lima \& M. Superina. 2014. Euphractus sexcinctus. The IUCN Red List of Threatened Species 2014: e. T8306A47441708.https://dx.doi.org/10.2305/IUCN. UK.2014-1.RLTS.T8306A47441708.en. Downloaded on 28 May 2021.

Aguirre, L., et al. 2019. Lista actualizada y comentada de los mamíferos de Bolivia. Ecología en Bolivia 54: 107-147.

Anacleto, T.C.S., P. Smith, A.M. Abba \& M. Superina. 2014. Dasypus septemcinctus. The IUCN Red List of Threatened Species 2014: e.T6293A47441509. https://dx.doi.org/10.2305/IUCN.UK.2014-1.RLTS. T6293A47441509.en. Downloaded on 27 May 2021.

Ayala, G. \& M.E. Viscarra. 2018. Densidad de jaguar y abundancia de mamíferos medianos y grandes en el río Heath, Parque Nacional ANMI Madidi (Bolivia) y Parque Nacional Bahuaja-Sonene (Perú), 2017. Informe técnico. Wildlife Conservation Society, La Paz, Bolivia.

Ayala, G., M.E. Viscarra, J. Martinez \& R. Porcel. 2017. Densidad de jaguar y abundancia relativa de mamíferos medianos y grandes en las estancias Santiago y el Mojón, Área Protegida Municipal Pampas del Yacuma, Beni, Bolivia, 2016. Informe técnico. Wildlife Conservation Society, La Paz, Bolivia.

Eisenberg, J.F. \& K.H. Redford 1999. Mammals of the Neotropics, Volume 3. The Central Neotropics: Ecuador, Peru, Bolivia, Brazil. The University of Chicago Press, Chicago.

Feijó, A. 2020. Dasypus septemcinctus (Cingulata: Dasypodidae). Mammalian Species 52(987): 1-9. https:// doi.org/10.1093/mspecies/sez022

Feijó, A., B.D. Patterson \& P. Cordeiro-Estrela. 2018. Taxonomic revision of the long-nosed armadillos, Genus Dasypus Linnaeus, 1758 (Mammalia, Cingulata). PLoS ONE 13(4): e0195084. https://doi.org/10.1371/ journal.pone.0195084
Identidad Madidi \& SERNAP. 2020. Informe de la expedición científica Identidad Madidi 2017. Relevamientos de biodiversidad en el Parque Nacional y Área Natural de Manejo Integrado Madidi. La Paz, Bolivia.

Montambault, J.R. 2002. Informes de las evaluaciones biológicas de Pampas del Heath, Perú, Alto Madidi, Bolivia, y Pando, Bolivia. Conservation International, Washington, DC.

Noss, A., E. Cuellar, H. Gómez, T. Tarifa \& E. Aliaga-Rossel. 2010. Dasypodidae. Pp. 175-212 in: Distribución, ecología y conservación de los mamíferos medianos y grandes de Bolivia (R. Wallace, H. Gómez, Z. Porcel \& D. Rumiz, eds.). Centro de Ecología y Difusión Simón I. Patino, Santa Cruz de la Sierra, Bolivia.

Superina, M. \& A.M. Abba. 2020. Conservation perspectives for a highly disparate lineage of mammals: The Xenarthra. Mastozoología Neotropical 27: 48-67. https://doi.org/10.31687/saremMN_SI.20.27.1.06

Superina, M. \& A.M. Abba. 2018. Family Chlamyphoridae (Chlamyphorid armadillos). Pp. 48-73 in: Handbook of the mammals of the world. Volume 8: insectivores, sloths and colugos (D.E. Wilson \& R. A. Mittermeier, eds.). Lynx Edicions, Barcelona.

Tarifa, T. \& L. Aguirre. 2009. Mamíferos. Pp. 419-445 in: Libro rojo de la fauna silvestre de vertebrados de Bolivia (L.F. Aguirre, R. Aguayo, J.A. Balderrama, C. Cortez, T. Tarifa \& O. Rocha O., eds.). Ministerio de Medio Ambiente y Agua, La Paz, Bolivia.

Wallace, R. B., H. Lopez-Strauss, N. Mercado \& Z.R. Porcel. 2013. Base de datos sobre la distribución de los mamíferos medianos y grandes de Bolivia. DVD Interactivo. Wildlife Conservation Society, La Paz, Bolivia.

Wetzel, R.M. 1985. Taxonomy and distribution of armadillos, Dasypodidae. Pp. 23-46 in: The evolution and ecology of armadillos, sloths and vermilinguas (G.G. Montgomery, ed.). Smithsonian Institution Press, Washington and London.

Received: 15 June 2021; Accepted: 27 September 2021 


\title{
COMUNICAÇÃO BREVE
}

\section{Primeiro registro de Myrmecophaga tridactyla (Pilosa, Myrmecophagidae) na região norte do Paraná, Brasil}

\author{
Marcelo Okamura Arasaki ${ }^{\mathrm{A}, \mathrm{B}, \mathrm{D}, 1}$, Alan Deivid Pereira ${ }^{\mathrm{C}}$, \\ Marcelo Hideki Shigaki Yabu ${ }^{C}$, Cleber Gustavo de Góes ${ }^{\mathrm{D}}$ \\ \& EduARdo IsSBERner PANACHÃO ${ }^{\mathrm{D}}$
}

\author{
A Programa de Pós-Graduação em Ciências Biológicas, Universidade Estadual de Londrina, \\ Campus Universitário, Rodovia Celso Garcia Cid, PR 445 Km 380, Caixa Postal 10.011, CEP 86.057-970, Londrina, Paraná, Brasil \\ E-mail: marcelo.arasaki@gmail.com (MOA) \\ ${ }^{\text {B }}$ Laboratório de Ecologia e Comportamento Animal, Universidade Estadual de Londrina, \\ Campus Universitário, Rodovia Celso Garcia Cid, PR 445 Km 380, Caixa Postal 10.011, CEP 86.057-970, Londrina, Paraná, Brasil
}

'Laboratório de Ecologia Aquática e Conservação de Espécies Nativas, Universidade Estadual de Londrina, Campus Universitário, Rodovia Celso Garcia Cid, PR 445 Km 380, Caixa Postal 10.011, CEP 86.057-970, Londrina, Paraná, Brasil E-mail: alandeivid bio@live.com (ADP), shigakimarcelo@gmail.com (MHSY)

${ }^{\text {D }}$ ONG Meio Ambiente Equilibrado, Rua Dr. Elias Cesar, 55, Ed. City Hall, sala 1101, Bairro Caiçaras, CEP 86015-640, Londrina, Paraná, Brasil E-mail: ogustavogoes@gmail.com (CGG), eduardoipanachao@gmail.com (EIP)

${ }^{1}$ Autor para correspondência.

Resumo Esta comunicação breve apresenta o primeiro registro de Myrmecophaga tridactyla (tamanduá -bandeira) para a região norte do estado do Paraná, Brasil, onde o bioma Mata Atlântica é densamente fragmentado e alterado em razão da crescente e recente urbanização e atividade agrícola desta região. O registro foi obtido em junho de 2021, em uma área urbana na zona norte do município de Londrina. A ocorrência da espécie até o presente momento para esta região era desconhecida, sendo as causas deste evento ainda pouco compreendidas. O registro destaca que a ocorrência da espécie nesta área urbanizada é apoiada por um fluxo atual na direção do norte do Paraná de indivíduos recentemente registrados à leste, que a paisagem é permeável para o deslocamento de animais terrestres na interface urbano/rural e que é provável tratar-se de um evento de dispersão recente da espécie em regiões com descaracterização de ambientes naturais.

Palavras-chave: área urbana, dispersão, Londrina, Mata Atlântica, tamanduá-bandeira

First record of Myrmecophaga tridactyla (Pilosa, Myrmecophagidae) in the northern Paraná State region, Brazil

Abstract This short communication presents the first record of Myrmecophaga tridactyla (giant anteater) for the northern region of the State of Paraná, Brazil, where the Atlantic Forest landscape is highly fragmented due to increasing urbanization and agricultural activity. The record was obtained in June 2021, in a northern urban zone of the municipality of Londrina. While we do not know the causes of this event, it may reflect a current flow towards the north of Paraná of individuals recently recorded to the east, perhaps facilitated by a permeable landscape for the displacement of terrestrial animals at the urban/rural interface, where disturbed natural environments are common.

Keywords: Atlantic Forest, dispersal, giant anteater, Londrina, urban zone 


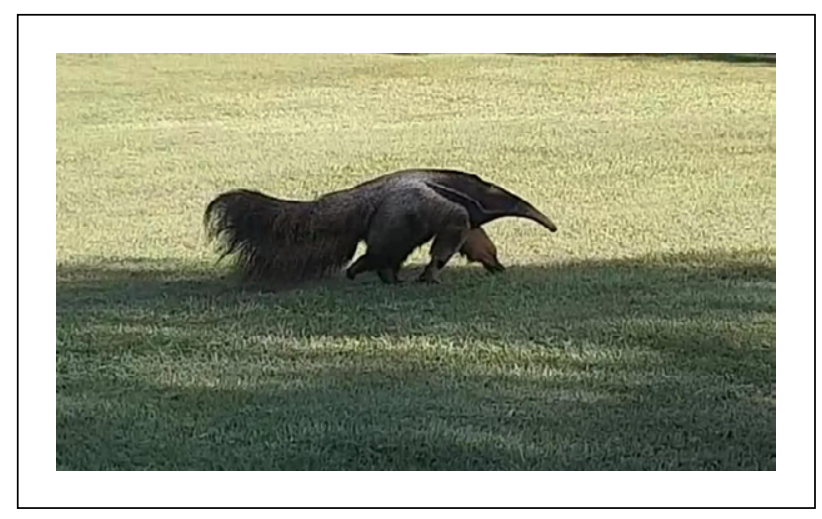

FIGURA 1. Frame do vídeo de M. tridactyla no gramado do Lago Norte, zona norte de Londrina, Paraná. Fonte: @instagram/londrina.animal

O tamanduá-bandeira (Myrmecophaga tridactyla Linnaeus, 1758) é uma espécie de grande porte $(\sim 45 \mathrm{~kg})$, sendo o maior representante atual da Ordem Pilosa (Reis et al., 2011). A dieta é predominantemente composta de formigas e cupins (Gallo et al., 2017). Myrmecophaga tridactyla é considerado de hábitos terrestres e com habilidade de escalada em cupinzeiros e árvores (Young et al., 2003). A espécie é amplamente distribuída na América do Sul e também no sul da América Central (Gardner, 2008), sendo recentemente documentada nos Andes (Figel et al., 2015). No Brasil, a espécie ocorre em todos os biomas (Paglia et al., 2012); contudo, as suas populações estão em declínio por toda sua área de ocorrência, com extinções locais e regionais já constatadas principalmente na porção sul de sua distribuição (Miranda et al., 2015).

Myrmecophaga tridactyla utiliza uma ampla variedade de habitats desde campos abertos, áreas inundáveis e florestas em diferentes níveis de perturbação (Diniz \& Brito, 2013). A espécie pode modificar o seu período de atividade dependendo da região e do grau de antropização (Bertassoni et al., 2019). A amplitude de ocorrência da espécie sobrepõe sua distribuição aos impactos das atividades humanas, onde se observa $M$. tridactyla utilizando áreas modificadas como pastagem, monoculturas e até mesmo áreas urbanizadas (Quiroga et al., 2016; Teixeira-Santos et al., 2020).

A dispersão atual da espécie para as áreas degradadas da Amazônia e Mata Atlântica sugere um efeito chamado de "savanização" sobre a fauna nos limites entre os biomas (Sales et al., 2020). Em decorrência do aumento cada vez maior de sua dispersão, a espécie fica mais propícia aos encontros com densas malhas rodoviárias, apresentando assim elevados índices de atropelamento nas rodovias brasileiras (Freitas et al., 2014; Pinto et al., 2018). Em decorrência dos diversos mecanismos que afetam a conservação e manutenção de populações viáveis de M. tridactyla, a espécie é classificada atualmente como Vulnerável (VU) às ameaças de extinção segundo a União Internacional para Conservação da Natureza (Miranda et al., 2014) e pelo Ministério do Meio Ambiente do Brasil (Miranda et al., 2018). No estado do Paraná a espécie é classificada como criticamente ameaçada de extinção (Paraná, 2010).

A ocorrência de M. tridactyla no estado do Paraná está relacionada principalmente às fitofisionomias de Cerrado e Campos Naturais, no centro-leste, além das planícies do Rio Paraná à oeste do estado (Hack \& Krüger, 2013; Miretzki \& Braga, 2014). Ainda assim são raros e fortuitos os registros mesmo em regiões onde sua presença é documentada, tornando novos registros uma importante fonte de dados para a compreensão da atual ocorrência dessa espécie. Santos et al. (2019) reuniu uma grande base de dados de M. tridactyla na região Neotropical de maneira a preencher as lacunas de informações sobre a ocorrência desta e de outras espécies de xenartros. Neste sentido, o objetivo desta nota é documentar o primeiro registro de M. tridactyla para a região norte do Estado do Paraná, destacando sua ocorrência em uma área urbanizada no município de Londrina.

O primeiro registro foi obtido mediante a um vídeo viral nas redes sociais em uma área de recreação $\left(23^{\circ} 16^{\prime} 11,4^{\prime \prime S}, 51^{\circ} 09^{\prime} 18,6^{\prime \prime} \mathrm{O}\right)$ da zona norte do município de Londrina. O vídeo apresenta um indivíduo de $M$. tridactyla caminhando em área aberta no dia 24 de junho de 2021. Este local é uma área de lazer, com gramados e pequenas porções de floresta bastante degradadas, não considerada uma Unidade de Conservação (FIG. 1). Outros vídeos posteriormente registraram o indivíduo percorrendo áreas urbanas do entorno, cruzando ruas e avenidas (FIG. 2) até se estabelecer em outro ponto

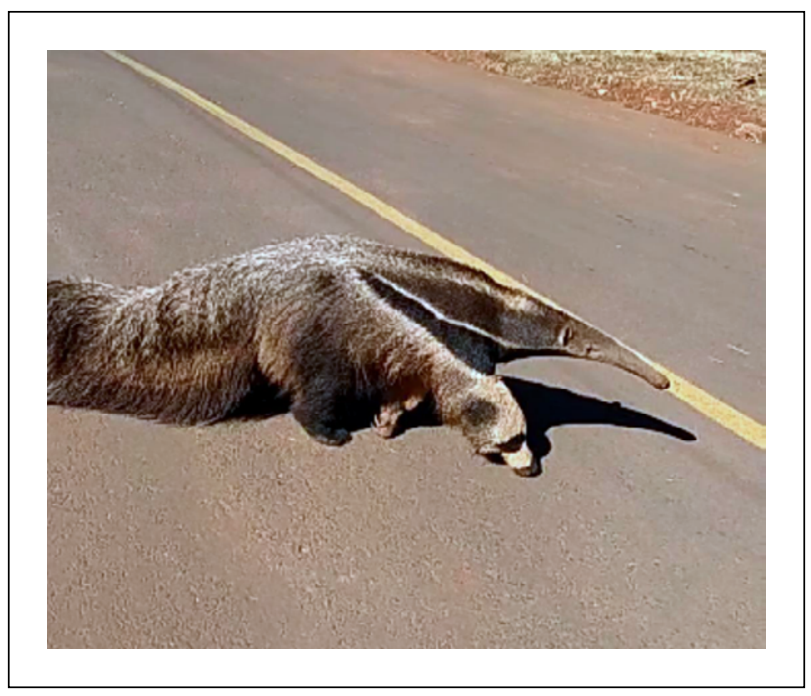

FIGURA 2. Frame do vídeo de M. tridactyla atravessando a rua do entorno urbanizado do Lago Norte, zona norte de Londrina, PR. Fonte: autor desconhecido. 


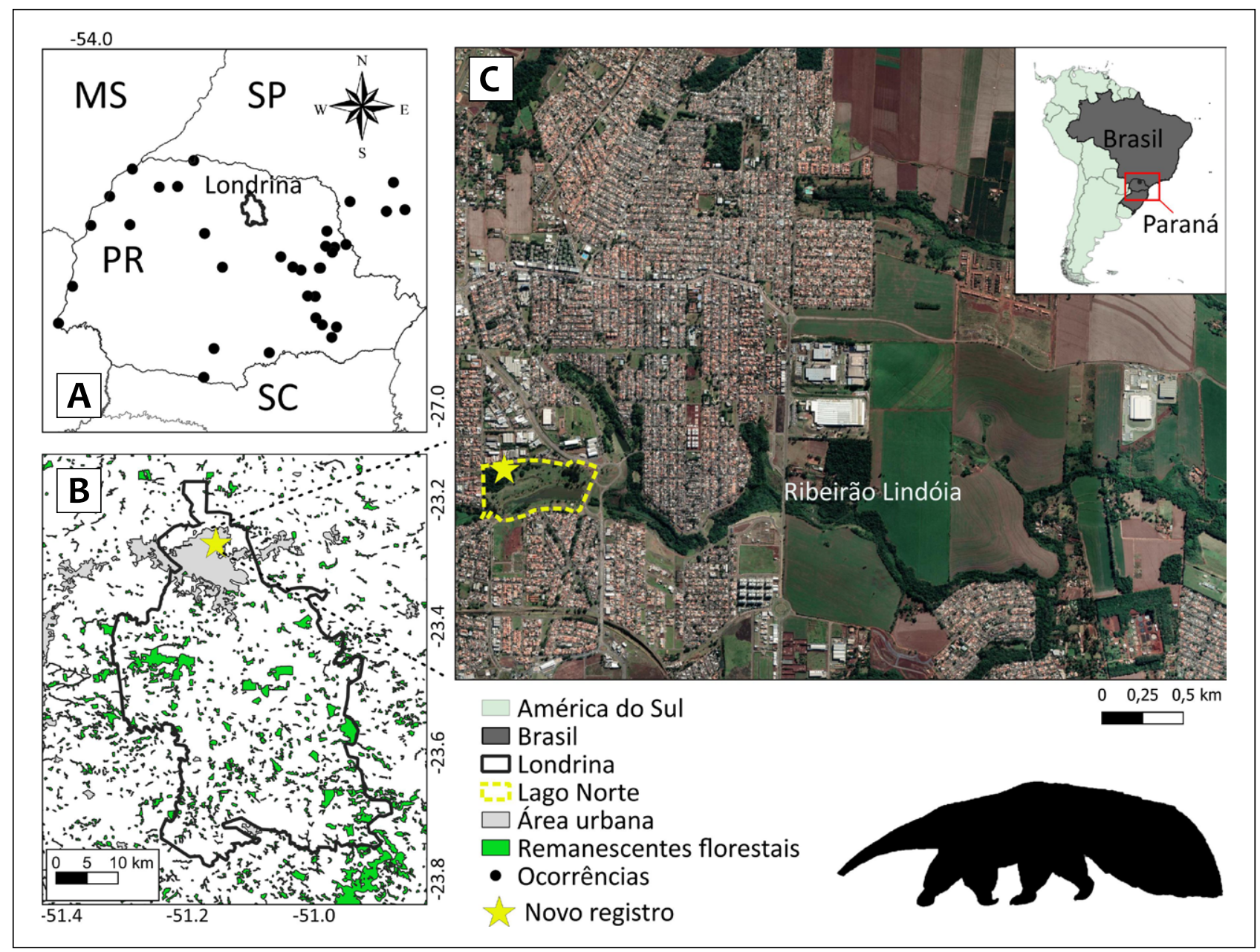

FIGURA 3. A. Registros de ocorrência do tamanduá-bandeira Myrmecophaga tridactyla em áreas protegidas no Brasil conforme Miranda et al. (2018) e Santos et al. (2019), e ocorrências no estado do Paraná conforme Miretzki \& Braga (2014). B. Mapa do registro de M. tridactyla na região norte do Estado do Paraná. C. Imagem de satélite da posição do registro e localização na América do Sul.

da área de recreação próximo ao primeiro registro (FIG.3).

A ocorrência deste indivíduo de M. tridactyla nas determinadas circunstâncias foi tratada como de risco ao animal, uma vez que há referências de perturbação por animais domésticos no entorno de Unidades de Conservação (Lacerda et al., 2009) e que vias pavimentadas podem ser consideradas armadilhas ao atropelamento da espécie (Noonan et al., 2021). Também foi constatado o risco aos humanos (Haddad Jr. et al., 2014), já que a espécie é regionalmente pouco conhecida e estava sendo tratada como um animal de estimação perante aos freqüentadores do local.

Após o resgate do indivíduo em situação de risco, foi constatado se tratar de uma fêmea adulta de M. tridactyla $(\sim 31 \mathrm{~kg})$. Um indivíduo monitorado da espécie se deslocou em média 1320 metros por dia, e apresentou uma área de vida de $2,46 \mathrm{~km}^{2}$ (Bertassoni et al., 2017). As fêmeas da espécie apresentam áreas de vida média aproximadamente $25 \%$ menores que os machos (Braga et al., 2010; Di Blanco et al., 2017). Somente Shaw et al. (1987) descreve a área de vida média de uma fêmea relativamente maior do que para machos de M. tridactyla.

Este registro na região norte do Estado do Paraná estende a ocorrência de $M$. tridactyla por aproximadamente $125 \mathrm{~km}$ do registro no município de Fênix à sudoeste, $175 \mathrm{~km}$ do registro em Telêmaco Borba ao sul e $240 \mathrm{~km}$ do registro no município de Jaguariaíva à sudeste (Hack \& Krüger, 2013; Miretzki \& Braga, 2014). Estes movimentos de dispersão estão sendo descritos atualmente para a Mata Atlântica impulsionados pela fragmentação dos ecossistemas florestais do bioma (Passos et al., 2016; Dias et al., 2019). Atualmente, foram descritos pontos de ocorrência da espécie à leste deste registro, na divisa dos estados do Paraná e São Paulo, que sugerem a possibilidade de um fluxo atual de indivíduos em direção ao norte do Paraná (Santos et al., 2019). Os impactos sobre os ecossistemas de cerrado e no ecótono entre o Cerrado e a Mata Atlântica também podem influenciar estes eventos (Zimbres et al., 2012; Sales et al., 2020). 
Com o registro de $M$. tridactyla em Londrina podemos inferir que: 1) a extensão da ocorrência da espécie proposta neste trabalho amplia os registros publicados, sendo presumido um fluxo atual de indivíduos que ocorrem à leste; 2) que há permeabilidade nesta paisagem para o deslocamento de animais terrestres das áreas rurais em direção às áreas urbanas; e 3) esta ocorrência pode ser relacionada à dispersão recente da espécie nas regiões com descaracterização de ambientes naturais.

\section{AGRADECIMENTOS}

Agradecemos à Polícia Militar Ambiental (Força Verde) e ao Instituto Água e Terra (IAT) pelo apoio técnico legal; aos médicos veterinários Dr. Guilherme S. Cardoso e MSc. Andressa M.R.N. de Matos pelo suporte veterinário; aos biólogos Vitor Prado e Henrique Rocha, e ao farmacêutico Ricardo L.N. de Matos pelo apoio logístico; e aos amigos do canal @instagram/londrina.animal pelo apoio voluntarioso e divulgação da proteção da fauna silvestre em Londrina.

\section{REFERÊNCIAS}

Bertassoni, A., G. Mourão, R. C. Ribeiro, C.S. Cesário, J.P. de Oliveira \& R.D.C. Bianchi. 2017. Movement patterns and space use of the first giant anteater (Myrmecophaga tridactyla) monitored in São Paulo State, Brazil. Studies on Neotropical Fauna and Environment 52: 68-74. https://doi.org/10.1080/01650521. 2016.1272167

Bertassoni, A., R.T. Costa, J.A. Gouvea, R.D.C. Bianchi, J.W. Ribeiro, M.H. Vancine \& M.C. Ribeiro. 2019. Land-use changes and the expansion of biofuel crops threaten the giant anteater in southeastern Brazil. Journal of Mammalogy 100: 435-444. https:// doi.org/10.1093/jmammal/gyz042

Braga, F. G., R.E.F. Santos \& A.C. Batista. 2010. Marking behavior of the giant anteater Myrmecophaga tridactyla (Mammalia: Myrmecophagidae) in southern Brazil. Zoologia 27: 7-12. https://doi.org/10.1590/ S1984-46702010000100002

Dias, D.M., F.R. Miranda \& F.H.G. Rodrigues. 2019. New record of giant anteater Myrmecophaga tridactyla (Pilosa, Myrmecophagidae) in Northeast Brazil. Neotropical Biology and Conservation 14: 129-135. https://doi.org/10.3897/neotropical.14.e34842

Di Blanco, Y.E., A. L.J. Desbiez, I. Jiménez-Pérez, D. Kluyber, G.F. Massocato \& M.S. Di Bitetti. 2017. Habitat selection and home-range use by resident and reintroduced giant anteaters in 2 South American wetlands. Journal of Mammalogy 98: 1118-1128. https://doi.org/10.1093/jmammal/gyx019

Diniz, M.F. \& D. Brito. 2013. Threats to giant anteater, Myrmecophaga tridactyla (Pilosa: Myrmecophagidae), viability in a protected Cerrado remnant encroached by urban expansion in central Brazil. Zoologia 30: 151-156. https://doi.org/10.1590/ S1984-46702013000200005
Figel, J.J., S. Botero-Cañola, J.D. Sánchez-Londoño \& A. Quintero-Ángel. 2015. Unexpected documentation and inter-Andean range expansion of a vulnerable large mammal (Mammalia, Pilosa, Myrmecophaga tridactyla) in Colombia. Mammalia 80: 449-452. https://doi.org/10.1515/mammalia-2015-0037

Freitas, C.H., C.S. Justino \& E.Z.F. Setz. 2014. Roadkills of the giant anteater in southeastern Brazil: 10 years monitoring spatial and temporal determinants. Wildlife Research 41: 673-680. https://doi. org/10.1071/WR14220

Gallo, J.A., A. M. Abba, L. Elizalde, D. Di Nucci, T. A. Ríos \& M.C. Ezquiaga. 2017. First study on food habits of anteaters, Myrmecophaga tridactyla and Tamandua tetradactyla, at the southern limit of their distribution. Mammalia 81: 601-604. https://doi.org/10.1515/ mammalia-2016-0117

Gardner, A.L. 2008. Mammals of South America, Volume 1: marsupials, shrews, and bats. University of Chicago Press, Chicago. https://doi.org/10.7208/ chicago/9780226282428.001.0001

Hack, R.O.E. \& F.A. Krüger. 2013. Novos registros de Myrmecophaga tridactyla (Mammalia: Xenarthra) no Estado do Paraná, Brasil. Edentata 14: 70-73. https:// doi.org/10.5537/020.014.0109

Haddad Jr., V., G.C. Reckziegel, D. G. Neto \& F. L. Pimentel. 2014. Human death caused by a giant anteater (Myrmecophaga tridactyla) in Brazil. Wilderness \& Environmental Medicine 25: 446-449. https://doi. org/10.1016/j.wem.2014.04.008

Lacerda, A.C.R., W.M. Tomas \& J. Marinho-Filho. 2009. Domestic dogs as an edge effect in the Brasília National Park, Brazil: interactions with native mammals. Animal Conservation 12: 477-487. https://doi. org/10.1111/j.1469-1795.2009.00277.x

Miranda, F., A. Bertassoni \& A. M. Abba. 2014. Myrmecophaga tridactyla. The IUCN Red List of Threatened Species 2014: e.T14224A47441961. https://dx.doi.org/ 10.2305/IUCN.UK.2014-1.RLTS.T14224A47441961. en. Acesso em 25 de outubro de 2021.

Miranda, F.R., et al. 2015. Avaliação do risco de extinção de Myrmecophaga tridactyla Linnaeus, 1758 no Brasil. Disponível em: http://www.icmbio.gov.br/ portal/biodiversidade/fauna-brasileira/lista-de-especies/7049-mamiferosmyrmecophaga-tridactylatamandua-bandeira.html

Miranda, F. R., et al. 2018. Myrmecophaga tridactyla Linnaeus 1758. Pp. 40-46 in: Livro Vermelho da fauna brasileira ameaçada de extinção: Volume II - Mamíferos (ICMBio, ed.). ICMBio/MMA, Brasília, DF.

Miretzki, M. \& F. G. Braga. 2014. Distribuição histórica e recente de Myrmecophaga tridactyla Linnaeus, 1758 (Pilosa, Myrmecophagidae) no Estado do Paraná, Brasil. Edentata 15: 16-26. https://doi.org/10.5537/ 020.015 .0113

Noonan, M.J., F. Ascensão, D.R. Yogui \& A.L.J. Desbiez. 2021. Roads as ecological traps for giant anteaters. Animal Conservation. https://doi.org/10.1111/acv.12728 
Paglia, A. P., et al. 2012. Lista anotada dos mamíferos do Brasil / Annotated checklist of Brazilian mammals. $2^{\text {nd }}$ edition. Conservation International, Arlington.

Paraná - Sistema Estadual de Legislação. 2010. Decreto 7264/2010 Reconhece e atualiza a lista de espécies de mamíferos pertencentes à fauna silvestre ameaçadas de extinção no Estado do Paraná. Casa Civil, Curitiba, PR.

Passos, F.C., M.H. Mello, E. Inasi-Catalá, R.C. Mello, I.P. Bernardi, L.H. Varzinczak \& C.S. Lima. 2017. The Vulnerable giant anteater Myrmecophaga tridactyla: new records from the Atlantic Forest highlands and an overview of its occurrence in protected areas in Brazil. Oryx 51: 564-566. https://doi.org/10.1017/ S0030605316000740

Pinto, F.A.S., A. Bager, A.P. Clevenger \& C. Grilo. 2018. Giant anteater (Myrmecophaga tridactyla) conservation in Brazil: Analysing the relative effects of fragmentation and mortality due to roads. Biological Conservation 228: 148-157. https://doi.org/10.1016/j. biocon.2018.10.023

Quiroga, V.A., A.J. Noss, G.I. Boaglio \& M.S. Di Bitetti. 2016. Local and continental determinants of giant anteater (Myrmecophaga tridactyla) abundance: Biome, human and jaguar roles in population regulation. Mammalian Biology 81: 274-280. https://doi. org/10.1016/j.mambio.2016.03.002

Reis, N. R., A. L. Peracchi, W. A. Pedro \& I.P. Lima (Eds.). 2011. Mamíferos do Brasil. $2^{\text {a }}$ Edição. Londrina, PR. 439 pp.
Sales, L.P., M. Galetti \& M.M. Pires. 2020. Climate and land-use change will lead to a faunal "savannization" on tropical rainforests. Global Change Biology 00: 1-9. https://doi.org/10.1111/gcb.15374

Santos, P.M., et al. 2019. Neotropical Xenarthrans: a data set of occurrence of xenarthran species in the Neotropics. Ecology 100(7): e02663. https://doi. org/10.1002/ecy.2663

Shaw, J.H., J. Machado-Neto \& T.S. Carter. 1987. Behavior of free-living giant anteaters (Myrmecophaga tridactyla). Biotropica 3: 255-259. https://doi.org/ $10.2307 / 2388344$

Teixeira-Santos, J., A.C.C. Ribeiro, O. Wiig, N.S. Pinto, L. G. Cantanhêde, L. Sena \& A.C. Mendes-Oliveira. 2020. Environmental factors influencing the abundance of four species of threatened mammals in degraded habitats in the eastern Brazilian Amazon. PLoS One 15(2): e0229459. https://doi.org/10.1371/ journal.pone.0229459

Young, R.J., C.M. Coelho \& D.R. Wieloch. 2003. A note on the climbing abilities of giant anteaters, Myrmecophaga tridactyla (Xenarthra, Myrmecophagidae). Boletim do Museu de Biologia Mello Leitão (Nova série) 15: 41-46.

Zimbres, B.Q.C., et al. 2013. The impact of habitat fragmentation on the ecology of xenarthrans (Mammalia) in the Brazilian Cerrado. Landscape Ecology 28: 259269. https://doi.org/10.1007/s10980-012-9832-2

Recebido em: 19 de agosto de 2021; Aceito em: 27 de outubro de 2021 


\title{
SHORT COMMUNICATION
}

\section{Record of the silky anteater (Cyclopes didactylus; Xenarthra: Cyclopedidae) in the Atlantic Forest of Rio Grande do Norte state, northeastern Brazil}

\author{
Paulo Henrique Dantas Marinho ${ }^{A, 1}$, Luiz Yoshihiro Garcia de Lima Hagi ${ }^{\mathrm{B}}$, \\ Bruno Rodrigo de Albuquerque França ${ }^{B}$ \& Liana Mara Mendes de Sena ${ }^{C}$
}

A Universidade Federal do Rio Grande do Norte, Programa de Pós-graduação em Ecologia, Campus Universitário, 59078-970, Natal, Rio Grande do Norte, Brasil

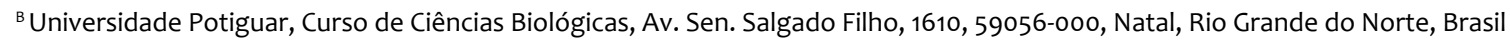

c Universidade Federal de Minas Gerais, Programa de Pós-graduação em Ecologia e Conservação da Vida Silvestre, Av. Antônio Carlos, 6627, 31270-901, Belo Horizonte, Minas Gerais, Brasil

${ }^{1}$ Corresponding author. E-mail: phdmarinho2@gmail.com

\begin{abstract}
Information on the distribution of the silky anteater (Cyclopes didactylus) is scarce, especially in the Atlantic Forest of northeastern Brazil, where the species is considered Data Deficient (DD) by the IUCN. We present the first georeferenced record of $C$. didactylus for the Atlantic Forest of Rio Grande do Norte, northeastern Brazil. A resident found the animal in 2008 near a Private Reserve of Natural Heritage in the municipality of Baía Formosa, in the surroundings of the largest Atlantic Forest fragment of the state. Our record represents the northernmost known location of the Atlantic Forest for C. didactylus. Given the likely importance of the registration site for the conservation of this species, future research should investigate the current state of the population and distribution of $C$. didactylus in the region to support conservation actions that guarantee its persistence in a landscape under intense anthropogenic pressure.
\end{abstract}

Keywords: anteater, distribution area, mammal, Pernambuco Endemism Center, Pilosa

\begin{abstract}
Registro do tamanduaí (Cyclopes didactylus; Xenarthra: Cyclopedidae) na Floresta Atlântica do Rio Grande do Norte, nordeste do Brasil

Resumo Informações sobre a distribuição do tamanduaí (Cyclopes didactylus) são escassas, especialmente na Floresta Atlântica do nordeste do Brasil, onde a espécie é considerada Deficiente de Dados (DD) pela IUCN. Apresentamos aqui o primeiro registro georreferenciado de C. didactylus para a Floresta Atlântica do Rio Grande do Norte, nordeste do Brasil. O animal foi encontrado em 2008 por um morador nas imediações do maior fragmento de Floresta Atlântica do estado, onde existe uma Reserva Particular do Patrimônio Natural no município de Baía Formosa. Nosso registro representa a localização conhecida mais ao norte da Floresta Atlântica para C. didactylus. Considerando a provável importância do local do registro para a conservação desta espécie, futuras pesquisas devem investigar o estado atual da população e a distribuição de $C$. didactylus na região para subsidiar ações de conservação que garantam sua persistência em uma paisagem sob intensa pressão antrópica.
\end{abstract}

Palavras-chave: área de distribuição, Centro de Endemismo Pernambuco, Mamífero, Pilosa, tamanduá

The silky anteater (Cyclopes sp.) is one of the smallest and least known taxa of the superorder Xenarthra (Miranda \& Superina, 2010), and the smallest species of the order Pilosa, weighing approximately $300 \mathrm{~g}$ (Feijó \& Langguth, 2013). The species of the genus are nocturnal and exclusively arboreal (Miranda \& Superina, 2010; Hayssen et al., 2012). In association with its cryptic coloration 
these characteristics make field detection difficult and contribute to the lack of knowledge about this taxon (Feijó \& Langguth, 2013; Miranda et al., 2015). The largest database on the abundance and occurrence of neotropical xenarthrans shows that Cyclopes sp. has the smallest number of records among the studied taxa $(\mathrm{n}=240$, Santos et al., 2019). Cyclopes sp. feeds mainly on ants, but it may also

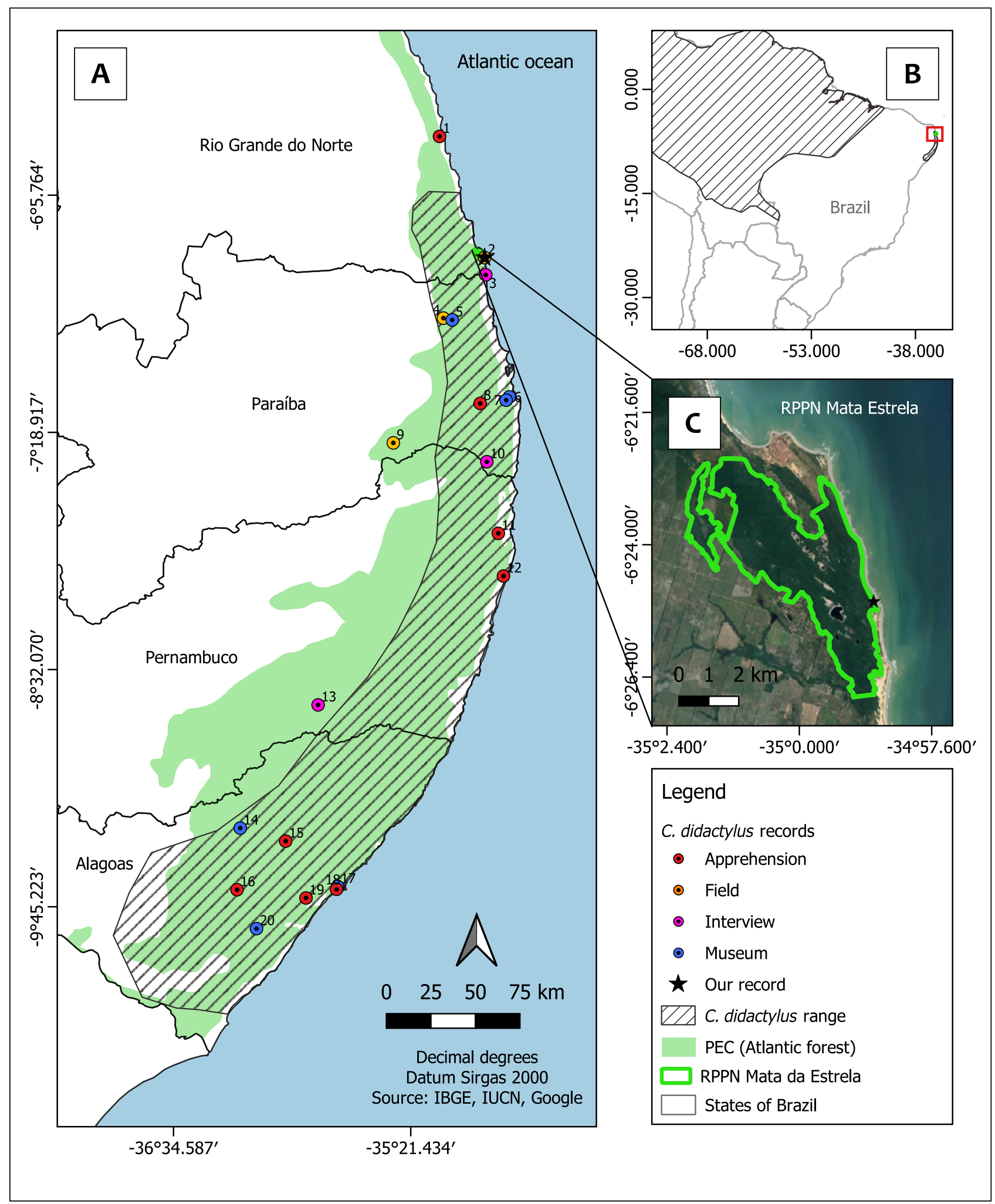

FIGURE 1. A. Location of Pernambuco Endemism Center in northeastern Brazil; B. Cyclopes didactylus records in the Pernambuco Endemism Center obtained through different survey methods, including primary and secondary data, and highlighting the new record presented here; C. location of Mata Estrela Private Reserve (RPPN) in Rio Grande do Norte state, near the place where the animal was found being kept by a fisherman. Literature records with geographic coordinates: 1, 8, 11, 12, 15, 16, 18, 19: Miranda \& Superina (2010); 9, 10: Santos et al. (2019); 5, 6, 7, 14, 17, 20: Feijó \& Langguth (2013); 4: Gonçalves et al. (2018); 3: Campos et al. (2018); 13: Silva \& Mendes Pontes (2008). 
TABLE 1. Location of the Cyclopes didactylus records in the Pernambuco Endemism Center of the Brazilian Atlantic Forest, including primary and secondary data, and highlighting the new record presented here at Mata Estrela Private Reserve in Rio Grande do Norte state. The numbers correspond to the records in FIGURE 1. Literature records that did not report geographic coordinates are not included, such as the records reported by Miranda et al. (2018) for the following locations: Rio São Francisco (Alagoas), Jaboatão dos Guararapes and Timbaúba (Pernambuco).

\begin{tabular}{|c|c|c|c|c|c|c|}
\hline No. & Source & Method & Municipality & State & Latitude & Longitude \\
\hline 1 & Miranda \& Superina, 2010 & Apprehension & Natal & Rio Grande do Norte & $5^{\circ} 47^{\prime} 39.0^{\prime \prime} \mathrm{S}$ & $35^{\circ} 12^{\prime} 33.34^{\prime \prime} \mathrm{W}$ \\
\hline 2 & This work & Field & Baia Formosa & Rio Grande do Norte & $6^{\circ} 25^{\prime} 2.03^{\prime \prime} \mathrm{S}$ & $34^{\circ} 58^{\prime} 39.19^{\prime \prime} \mathrm{W}$ \\
\hline 3 & Campos et al., 2018 & Interview & Mataraca & Paraíba & $6^{\circ} 30^{\prime} 21.5^{\prime \prime S}$ & $34^{\circ} 58^{\prime} 17.40^{\prime \prime} \mathrm{W}$ \\
\hline 4 & Goncalves et al., 2018 & Field & Mamanguape & Paraíba & $6^{\circ} 43^{\prime} 41.8^{\prime \prime S}$ & $35^{\circ} 11^{\prime} 21.51^{\prime \prime W}$ \\
\hline 5 & Feijó \& Langguth, 2013 & Museum & Mamanguape & Paraíba & $6^{\circ} 44^{\prime} 15.8^{\prime \prime S}$ & $35^{\circ} 8^{\prime} 38.63^{\prime \prime} \mathrm{W}$ \\
\hline 6 & Feijó \& Langguth, 2013 & Museum & João Pessoa & Paraíba & $7^{\circ} 7 ' 59.99 " \mathrm{~S}$ & $34^{\circ} 51^{\prime} 0.00^{\prime \prime} \mathrm{W}$ \\
\hline 7 & Feijó \& Langguth, 2013 & Museum & João Pessoa & Paraíba & $7^{\circ} 9^{\prime} 0.00 " \mathrm{~S}$ & $34^{\circ} 52^{\prime} 0.01^{\prime \prime} \mathrm{W}$ \\
\hline 8 & Miranda \& Superina, 2010 & Apprehension & Santa Rita & Paraíba & $7^{\circ} 10^{\prime} 0.00^{\prime \prime S}$ & $35^{\circ} 0^{\prime} 0.00^{\prime \prime} \mathrm{W}$ \\
\hline 9 & Santos et al., 2019 & Field & $\begin{array}{l}\text { Salgado de } \\
\text { São Félix }\end{array}$ & Paraíba & $7^{\circ} 22^{\prime} 10.5^{\prime \prime S}$ & $35^{\circ} 26^{\prime} 47.59^{\prime \prime} \mathrm{W}$ \\
\hline 10 & Santos et al., 2019 & Interview & Caapora & Paraíba & $7^{\circ} 27^{\prime} 59.8^{\prime \prime S}$ & $34^{\circ} 57^{\prime} 57.81^{\prime \prime W}$ \\
\hline 11 & Miranda \& Superina, 2010 & Apprehension & Igarassu & Pernambuco & $7^{\circ} 50^{\prime} 4.14^{\prime \prime} \mathrm{S}$ & $34^{\circ} 54^{\prime} 25.24^{\prime \prime} \mathrm{W}$ \\
\hline 12 & Miranda \& Superina, 2010 & Apprehension & Recife & Pernambuco & $8^{\circ} 3^{\prime} 14.78^{\prime \prime S}$ & $34^{\circ} 52^{\prime} 49.92^{\prime \prime W}$ \\
\hline 13 & Silva \& Mendes Pontes, 2008 & Interview & Jaqueira & Pernambuco & $8^{\circ} 43^{\prime} 0.00^{\prime \prime S}$ & $35^{\circ} 50^{\prime} 0.00^{\prime \prime} \mathrm{W}$ \\
\hline 14 & Feijó \& Langguth, 2013 & Museum & Viçosa & Alagoas & $9^{\circ} 21^{\prime} 0.00^{\prime \prime S}$ & $36^{\circ} 13^{\prime} 59.99^{\prime \prime} \mathrm{W}$ \\
\hline 15 & Miranda \& Superina, 2010 & Apprehension & Atalaia & Alagoas & $9^{\circ} 25^{\prime} 0.00^{\prime \prime S}$ & $36^{\circ} 0^{\prime} 0.00^{\prime \prime} \mathrm{W}$ \\
\hline 16 & Miranda \& Superina, 2010 & Apprehension & Anadia & Alagoas & $9^{\circ} 40^{\prime} 0.00^{\prime \prime} \mathrm{S}$ & $36^{\circ} 15^{\prime} 0.00^{\prime \prime} \mathrm{W}$ \\
\hline 17 & Feijó \& Langguth, 2013 & Museum & Maceió & Alagoas & $9^{\circ} 39^{\prime} 0.00^{\prime \prime S}$ & $35^{\circ} 43^{\prime} 59.99^{\prime \prime} \mathrm{W}$ \\
\hline 18 & Miranda \& Superina, 2010 & Apprehension & Maceió & Alagoas & $9^{\circ} 39^{\prime} 51.7 " \mathrm{~S}$ & $35^{\circ} 44^{\prime} 18.56^{\prime \prime W}$ \\
\hline 19 & Miranda \& Superina, 2010 & Apprehension & $\begin{array}{l}\text { Marechal } \\
\text { Deodoro }\end{array}$ & Alagoas & $9^{\circ} 42^{\prime} 32.4^{\prime \prime S}$ & $35^{\circ} 53^{\prime} 43.79^{\prime \prime} \mathrm{W}$ \\
\hline 20 & Feijó \& Langguth, 2013 & Museum & Manimbu & Alagoas & $9^{\circ} 52^{\prime} 0.00 " \mathrm{~S}$ & $36^{\circ} 9^{\prime} 0.00^{\prime \prime} \mathrm{W}$ \\
\hline
\end{tabular}

include beetles in its diet (Miranda et al., 2009; Hayssen et al., 2012; Miranda et al., 2015). Usually solitary, males and females only join during the breeding season, and the male may help take care of the offspring (Hayssen et al., 2012; Miranda et al., 2015).

Until recently, Cyclopes didactylus (Linnaeus, 1758) was the only recognized species of the genus, comprising seven subspecies (Miranda et al., 2015) that occurred in tropical forests from Central and South America to southern Mexico (Miranda et al., 2014). However, more recently, robust morphological, morphometric, and molecular analyses performed by Miranda et al. (2018) suggested the existence of at least seven valid species of the genus. Cyclopes didactylus now comprises disjunct populations in South America, one of them in the north of the Amazon forest, covering Venezuela, the Guyanas, and part of Brazil, reaching the Brazilian state of Piauí (Miranda et al., 2018). The other population of the species occurs in the Atlantic Forest of northeastern Brazil, including the states of Rio Grande do Norte, Paraíba, Pernambuco, and Alagoas (Miranda et al., 2018), one of the most biodiverse and threatened regions of the Atlantic Forest, known as Pernambuco Endemism Center (PEC) (Ribeiro et al., 

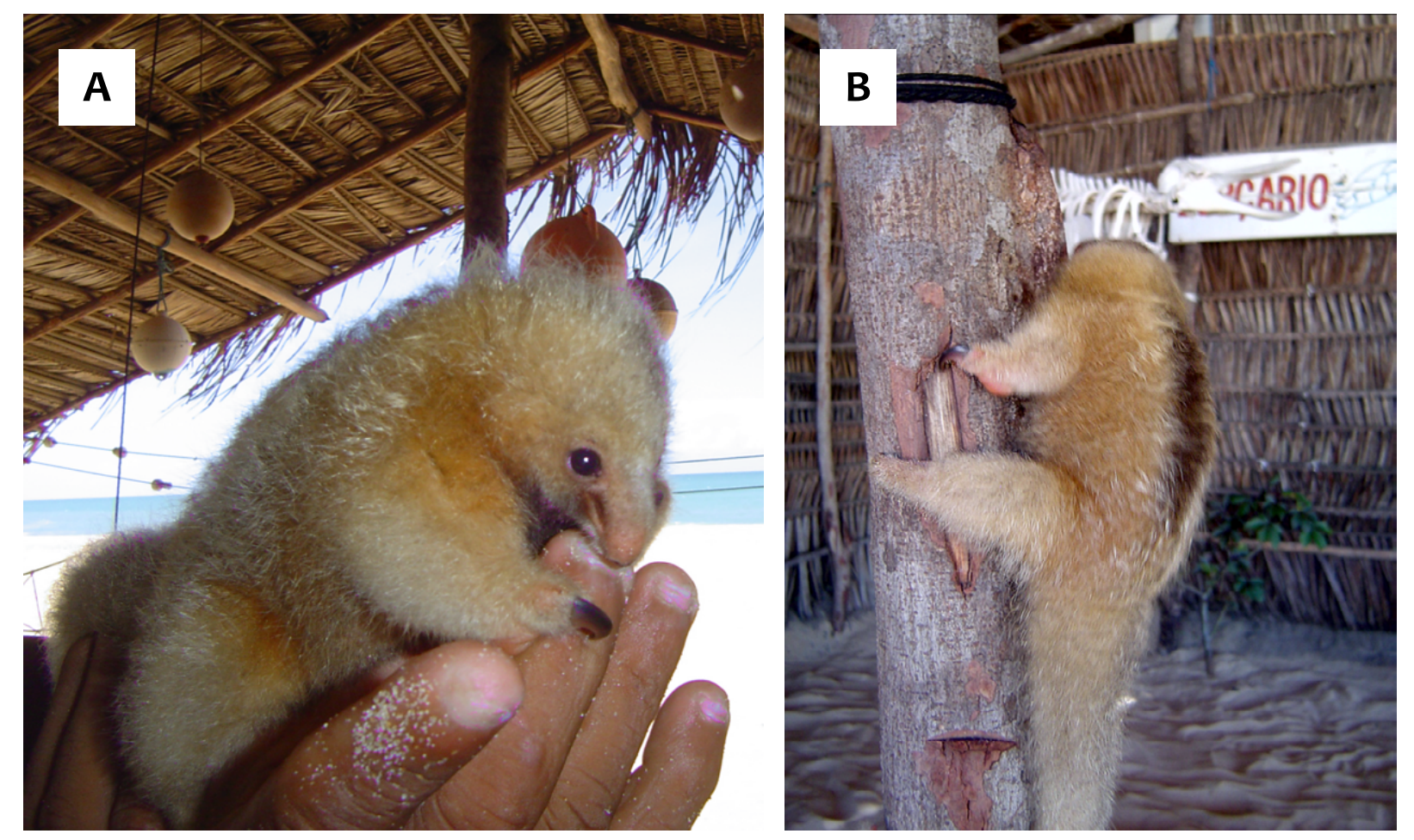

FIGURE 2. Specimen of Cyclopes didactylus found opportunistically in the municipality of Baía Formosa, Rio Grande do Norte, in 2008, while it was being held captive by a local fisherman. The characteristic dorsal stripes of the species can be observed in $\mathbf{B}$. Photographs by Luiz Yoshihiro Garcia de Lima Hagi.

2009). Morphologically, C. didactylus is the only Cyclopes species with clearly marked dorsal and ventral stripes (Miranda et al., 2018).

The recognition of the new species reinforces the need to improve knowledge about the ecology and distribution of the genus, especially to support conservation initiatives. While in its assessment prior to the taxonomic split $C$. didactylus was listed as Least Concern (LC) by the IUCN Red List of Threatened Species (Miranda et al., 2014) and by the latest Brazilian Red List, the disjunct population of northeastern Brazil was classified as Data Deficient (DD) (Miranda et al., 2015).

In this work, we present a record of $C$. didactylus obtained in 2008 in the vicinity of a private protected area in the Atlantic Forest ecoregion of Rio Grande do Norte, at the northern limit of the biome in northeastern Brazil.

The record presented here was opportunistically obtained in May 2008 by one of the authors (Luiz Yoshihiro Garcia de Lima Hagi; LYGLH) approximately $50 \mathrm{~m}$ away from the Mata Estrela Private Reserve of Natural Heritage (Mata Estrela Private Reserve) (06 $25^{\circ} 02^{\prime \prime} \mathrm{S}, 34^{\circ} 58^{\prime} 37^{\prime \prime}$ ' ; FIG. 1$)$, the largest remnant of Atlantic Forest in Rio Grande do Norte. The reserve encompasses approximately 2,040 ha, of which 1,888 ha are semideciduous forest, 82 ha dunes and restinga vegetation, and 70 ha lakes; its limits reach the coastline (Olmos, 2003). LYGLH met a fisherman with a silky anteater (FIG. 2). The fisherman, who lives on the beachfront, claimed to have found the specimen in the forest around the site (FIG. 3). LYGLH instructed him to return the silky anteater to the forest, but we could not confirm its fate.

Our record represents the northernmost occurrence location for the species in the northeastern Atlantic Forest. Only one documented record existed for Rio Grande do Norte, but the exact origin of that animal, which had been seized by the Instituto Brasileiro do Meio Ambiente e Recursos

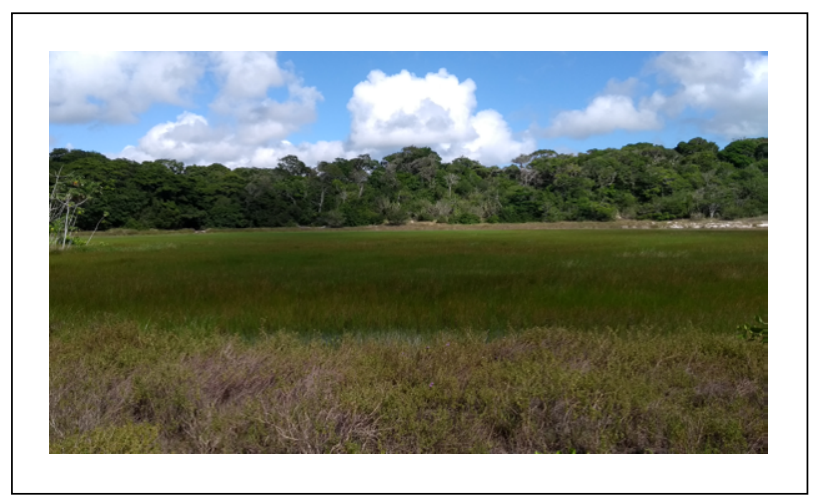

FIGURE 3. Atlantic Forest vegetation of the Mata Estrela Private Reserve in Baía Formosa, Rio Grande do Norte, where a local resident probably captured the specimen of Cyclopes didactylus presented in our study. Photo: Paulo Fernandes. 
Renováveis (IBAMA) (Miranda \& Superina, 2010), was unknown. Our record is $40 \mathrm{~km}$ from the closest record of the species with documented location, a museum specimen collected at Mamanguape in Paraíba (Feijó \& Langguth, 2013; Santos et al., 2019; FIG. 1, TABLE 1). Reports obtained from interviews point to the presence of the species in Mataraca, Paraíba, a municipality bordering Baía Formosa (Campos et al., 2018), 10 km from Mata Estrela Private Reserve (FIG. 1, TABLE 1).

The record presented here confirms the occurrence of the species in the surroundings of the private reserve (where it probably came from) in the Atlantic Forest domain on the south coast of Rio Grande do Norte. This record reinforces the relevance of the few protected areas of the PEC for the biome's biodiversity maintenance. Recent work has shown that private reserves have great relevance for PEC fauna conservation, especially in a context of high degradation and low coverage of protected areas (Carvalho et al., 2021). However, these areas are generally isolated and inserted in very fragmented landscapes (Carvalho et al., 2021), as is the case of Mata Estrela Private Reserve. The latter is surrounded by sugarcane monoculture and despite legal protection, it suffers from illegal hunting, extraction of firewood, and invasion of domestic animals (Costa-Neto, 2018), probably due to insufficient management and inspection. Therefore, the C. didactylus population as well as other iconic and forest-dependent species that occur in the region, such as the blonde capuchin monkey (Sapajus flavius) and the red-handed howler (Alouatta belzebul; Fialho et al., 2014), are likely to be at risk of local extinction.

Knowledge about the PEC mammals is still dramatically scarce and needs to advance to support conservation and management actions in an intensely fragmented landscape (Carvalho et al., 2021). Although our record is more than 10 years old and may generate some uncertainty about the current occurrence of the species in the area, the relative protection provided by the presence of a private reserve, as well as more recent interview data of a close region in Paraíba (Campos et al., 2018), suggest that the species should persist in the region, as advocated by Garbino et al. (2018). New surveys, however, are needed to confirm its current presence and define its population status and distribution in other fragments of the region. Conservation actions are urgently needed to guarantee the persistence of $C$. didactylus in the northern limit of the Atlantic Forest. These actions include the establishment of protected areas and ecological corridors, the fight against hunting and illegal deforestation, and educational actions that publicize the local fauna and sensitize the region's residents and the owners of large sugarcane plantations that contain forest fragments.

\section{ACKNOWLEDGEMENTS}

We thank the resident who provided the specimen information, Victoria Paixão for the English reviewing, the editors, and anonymous reviewers who helped improve this paper.

\section{REFERENCES}

Campos, B.A.T.P., A. Feijó, P.G.G. Brennand \& A.R. Percequillo. 2018. Mammals of a restinga forest in Mataraca, Paraíba, northeastern Brazil, and its affinities to restinga areas in Brazil. Biota Neotropica 18: e20170392. http://dx.doi.org/10.1590/16760611-BN-2017-0392

Carvalho, C.S., et al. 2021. Environmental heterogeneity and sampling relevance areas in an Atlantic forest endemism region. Perspectives in Ecology and Conservation 19: 311-3018. http://doi.org/10.1016/j. pecon.2021.05.001

Costa-Neto, P.F. 2018. Padrões de uso de habitat e coocorrência de aves do gênero Herpsilochmus (Thamnophilidae) em fragmento florestal no extremo Norte de distribuição da Mata Atlântica. Master's Thesis, Universidade Federal do Rio Grande do Norte, Natal. 50 pp.

Feijó, A. \& A. Langguth. 2013. Mamíferos de médio e grande porte do nordeste do Brasil: diversidade e taxonomia, com descrição de novas espécies. Revista Nordestina de Biologia 22: 3-227.

Fialho, M., M. Valença-Montenegro, T. Silva, J. Ferreira \& P. Laroque. 2014. Ocorrência de Sapajus flavius e Alouatta belzebul no centro de Endemismo Pernambuco. Neotropical Primates 211: 214-218. https:// doi.org/10.1896/044.021.0215

Garbino, G.S.T., G.C. Rezende, H. Fernandes-Ferreira \& A. Feijó. 2018. Reconsidering mammal extinctions in the Pernambuco Endemism Center of the Brazilian Atlantic Forest. Animal Biodiversity and Conservation 41.1: 175-184. https://doi.org/10.32800/ abc.2018.41.0175

Gonçalves, F. et al. 2018. Atlantic mammal traits: a data set of morphological traits of mammals in the Atlantic Forest of South America. Ecology 99: 498-498. https://doi.org/10.1002/ecy.2106

Hayssen, V., F. Miranda \& B. Pasch. 2012. Cyclopes didactylus (Pilosa: Cyclopedidae). Mammalian Species 44: 51-58. http://dx.doi.org/10.1644/895.1

Miranda, F. \& M. Superina. 2010. New distribution records of the silky anteater Cyclopes didactylus (Mammalia, Pilosa, Cyclopedidae) in coastal northeastern Brazil. Mastozoología Neotropical 17: 381-384.

Miranda, F., D. A. Meritt J., D. G. Tirira \& M. Arteaga. 2014. Cyclopes didactylus. The IUCN Red List of Threatened Species 2014: e.T6019A47440020. https://dx. doi.org/10.2305/IUCN.UK.2014-1.RLTS.T6019A47 440020.en. Downloaded on 22 August 2021.

Miranda, F.R., A.G. Chiarello, F. Röhe, G.H.B. Miranda \& S.M. Vaz. 2015. Avaliação do risco de extinção de Cyclopes didactylus (Linnaeus, 1758). Processo 
de avaliação do risco de extinção da fauna brasileira. Instituto Chico Mendes de Conservação da Biodiversidade. <http://www.icmbio.gov.br/portal/ biodiversidade/fauna-brasileira/lista-de-especies/ 7126-mamiferos-cyclopes-didactylus-tamandua-i. html $>$. Downloaded on 2 September 2021.

Miranda, F.R., D.M. Casali, F. Machado, F. Perini \& F.R. Santos. 2017. Taxonomic review of the genus Cyclopes Gray, 1821 (Xenarthra: Pilosa), with the revalidation and description of new species. Zoological Journal of the Linnean Society 183: 687-721. https:// doi.org/10.1093/zoolinnean/zlx079

Miranda, F.R., R. Veloso, M. Superina \& F.J. Zara. 2009. Food habits of wild silky anteaters (Cyclopes didactylus) of São Luís do Maranhão, Brazil. Edentata 8: 1-5.

Olmos, F. 2003. Birds of Mata Estrela private reserve, Rio Grande do Norte, Brazil. Cotinga 20: 26-30.
Ribeiro, M.C., J.P. Metzger, A.C. Martensen, F.J. Ponzoni \& M.M. Hirota. 2009. The Brazilian Atlantic Forest: how much is left, and how is the remaining forest distributed? Implications for conservation. Biological Conservation 142: 1141-1153. https://doi.org/10.1016/j. biocon.2009.02.021

Santos, P.M. et al. 2019. Neotropical Xenarthrans: a dataset of occurrence of xenarthran species in the neotropics. Ecology 100: e02663. https://doi.org/10.1002/ ecy.2663

Silva, A.P. \& A.R. Mendes Pontes. 2008. The effect of a mega-fragmentation process on large mammal assemblages in the highly-threatened Pernambuco Endemism Centre, north-eastern Brazil. Biodiversity and Conservation 17: 1455-1464. https://doi.org/10. 1007/s10531-008-9353-0

Received: 21 November 2021; Accepted: 14 December 2021 


\section{News}

\section{WELCOME TO OUR NEW SPECIALIST GROUP MEMBERS!}

One of the key results of the IUCN Species Strategic Plan 2021-2025, which was approved at the IUCN World Conservation Congress, is to enhance the membership and the capacity of the SSC network and its alliances, with a focus on increasing diversity among SSC members. In this context, our Specialist Group's membership committee decided to prioritize the inclusion of members from underrepresented countries until we have at least one member per range country. We would like to give a warm welcome to our new members from Bolivia, Chile, Costa Rica, French Guiana, Guyana, Honduras, and Uruguay. We would also like to take the opportunity to thank all existing members-both those who renewed their membership and those who decided to step down-for their enthusiasm and invaluable work. We are very much looking forward to working with all of you during this next quadrennium!

The IUCN Species Strategic Plan 2021-2025 is available at https://www.iucn.org/sites/dev/files/content/documents/iucn_species_strategic_plan_2021-2025_summary_1.pdf.

\section{PARTNERSHIP WITH THE FOUNDATION FOR INTERNATIONAL AID TO ANIMALS (FIAA)}

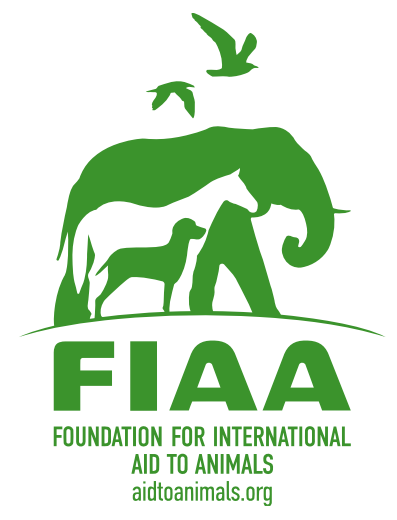

We are happy to announce that our Specialist Group has entered a partnership with the Foundation for International Aid to Animals (FIAA). FIAA is a private, non-profit organization based in New York City that promotes humane and responsible treatment and training of domestic animals and advocates wildlife conservation. Early on, FIAA understood the impact of feral animals on wildlife and supported educational programs, animal rescue, and population control operations for street dogs and cats. The institution then expanded its work to the conservation of wild species. For more than 20 years, FIAA has been developing and supporting wildlife management, rescue, rehabilitation, and reintroduction programs, cultivating collaborative efforts with partners and local groups on different continents.

Among others, FIAA will support the Anteater, Sloth and Armadillo Specialist Group's educational and awareness programs and conservation actions, including rescue and rehabilitation. We are looking forward to a fruitful collaboration between our Specialist Group and our partners FIAA and Nurtured by Nature!

If you would like to know more about FIAA, please visit their website at https://www.aidtoanimals.org.

\section{TAXONOMY SUBCOMMITTEE}

A taxonomy subcommittee of the ASASG has been constituted to perform the species taxonomy update to be used in the next IUCN Red List reassessment. Members of the subcommittee Frédéric Delsuc, Agustín Abba, Nadia Moraes-Barros, Maria-Clara Arteaga, Paul Smith, Mariella Superina, and Jim Loughry met virtually on June 30, 2021 to discuss and define the criteria they will use to evaluate newly proposed changes in xenarthran taxonomy.

Speciation being by essence a continuous and ongoing evolutionary process ultimately leading to the formation of new species from diverging populations, species delineation is particularly challenging. It is nevertheless vital for conservation biology to define practical evolutionarily significant units as populations of organisms that are considered distinct enough to assess their conservation status separately. Thanks to the developments of molecular genetic tools and their application in modern taxonomy, studies on species delineation proposing taxonomic changes in many taxa are flourishing. This underlines the crucial need to define objective criteria to accept or reject 
proposed taxonomic changes. Xenarthrans are still currently understudied from this point of view but there have been recent updates and proposals for taxonomic changes that need to be assessed before designing conservation policies. The goal of the meeting was thus to develop a procedure for making decisions on acceptance or rejection of proposed taxonomic changes (i.e. description of new species, splitting or lumping of existing species, declaring a taxon invalid, nomenclatural changes). The subcommittee recognizes that an integrative approach is needed and should consider multiple lines of evidence (morphology, genetics, biogeography, behavior, ecology, etc.). However, it is rare that a single study contains all these multiple lines of evidence.

Therefore, after fruitful discussions, the taxonomy subcommittee proposes a list of criteria upon which it will base its decisions by weighting the available evidence for a given taxonomic change on a case-by-case basis. In the case of conflicting lines of evidence, the subcommittee will follow the suggestion of the IUCN Red List Unit to adopt a conservative approach (i.e. prevailing usage):

- Only formal taxonomic changes proposed in studies published in a peer-reviewed scientific journal and following the rules of the International Code of Zoological Nomenclature (ICZN: https://www.iczn.org/the-code/the-codeonline/) will be considered.

- The subcommittee will evaluate the multiple lines of evidence provided in favor of the proposed taxonomic change in the given study and evaluate their respective strengths.

- The subcommittee will make sure that morpho-anatomical studies are based on properly deposited museum specimens and consider an adequate number of specimens representing the species geographical distribution, that must include the type locality.

- Studies based on geometric morphometrics will be assessed based on their respect of methodological standards for landmark definition and placements but also on the adequacy and significance of subsequent statistical analyses.

- Molecular studies of species delineation should ideally include analyses of both mitochondrial and nuclear markers for a representative sample of individuals covering the species distribution. As a minimum number of genes/markers could not be defined, the subcommittee members will assess the evidence provided in light of current practices in species delineation. This now mostly relies on complete mitochondrial genomes and multiple genome-wide nuclear markers obtained from reduced-genome representation methods (exon capture, UCEs,
Genotyping-By-Sequencing, RAD-seq) or lowcoverage genome sequencing (SNPs). The committee will verify that the molecular data underlying such studies have been properly deposited in a dedicated sequence repository such as GenBank, the European Nucleotide Archive, or the DNA Data Bank of Japan (DDBJ) and are publicly available.

- In specific cases, the subcommittee might consult with an external taxonomic expert to help reach a final decision.

These criteria provide the guidelines to make a decision, but are by no means exhaustive, and the taxonomy subcommittee will assess every case based on its own merits. Each decision will be subjected to a majority vote within the taxonomy subcommittee, then communicated to the other ASASG members to collect their opinion. The taxonomy subcommittee will publish a final statement detailing the arguments for or against a proposed taxonomic change in support of its decision. These will be published on the ASASG website as part of the species description pages. Taxonomic notes will be used to this effect and will highlight weaknesses and missing data in the assessments, in order to clarify avenues of further study necessary to fill the gaps in our knowledge.

As most of the xenarthran chapters of the Handbook of the Mammals of the World Volume 8 were written by ASASG members, the new species assessments will use this publication as the baseline reference.

\section{EDUCATION SUBCOMMITTEE}

The Education/Outreach subcommittee, consisting of Tinka Plese, Diorene J. Smith Cabellos, Alessandra Bertassoni, Nadia Moraes-Barros, Adriana Aguilar Borbón and Monique Pool, met several times after the $2^{\text {nd }}$ of March of this year. After several meetings in which Mariella Superina regularly participated, the subcommittee members agreed that Education/Outreach would focus on three topics:

1. Making the general public aware of xenarthrans and their conservation status.

2. Promoting international sloth day (third Saturday of October) and world anteater day (29 November) in xenarthran range countries.

3. Raising awareness about the Pygmy sloth through a Pygmy sloth website.

With a considerable effort by the members of the subcommittee, and with generous financial support from Nurtured by Nature, this website is now up and running. 
In the meantime, Alessandra Bertassoni took the lead on creating the ASASG's Instagram account, introducing those members of the Specialist Group who provided a picture and a quote.

Looking ahead, the focus will be on making the general public aware of xenarthrans and their conservation status. The subcommittee hopes all Specialist Group members will support these activities, and others, as we move forward.

Pygmy sloth website: https://pygmysloth.org and https://perezosopigmeo.org

ASASG's Instagram account (@asasg_2021):

https://www.instagram.com/asasg_2021/?hl=en

\section{RE-ASSESSMENT OF ALL XENARTHRA FOR THE IUCN RED LIST OF THREATENED SPECIES}

Our Specialist Group has initiated the re-assessment process of all Xenarthra for the IUCN Red List of Threatened Species. As suggested by our Taxonomy Subcommittee, we have started with the six sloth species. We will then continue with the anteaters, including the recently recognized new Cyclopes species. We hope to conclude the assessment of all Xenarthra by the end of 2022.

\section{TERESA CRIStinA ANACLeto (1961-2021)}

The IUCN SSC Anteater, Sloth and Armadillo Specialist Group deeply regrets the passing of professor and researcher Teresa Cristina da Silveira Anacleto, one of the great scientists in Brazil regarding the study of mammals. Teresa obtained a degree in Biological Sciences from the University of Guarulhos, a master's degree from the University of Brasilia on the ecology of the giant armadillo, and a doctorate from the Federal University of Goiás on the effects of anthropic actions, as well as the distribution and diet, of armadillos in the Cerrado.

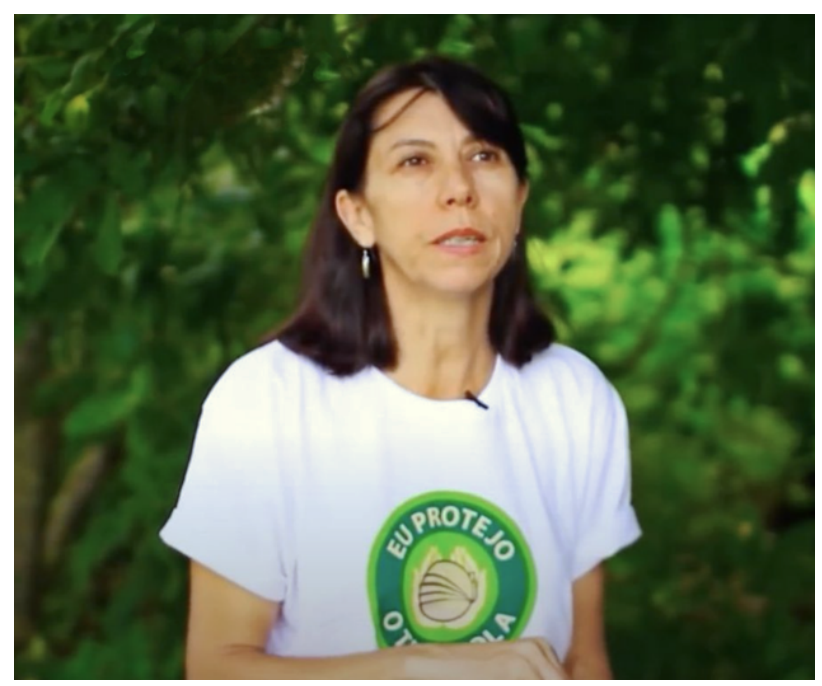

She was a professor at Mato Grosso State University, Nova Xavantina campus, where she mentored several students in the graduate program in ecology and trained generations of researchers and scientists. She worked at the Mammal Laboratory and its regional collection until she passed away.

Teresa was one of Brazil's leading armadillo specialists, and one of the most respected experts at the international level. During her extensive career, she studied the taxonomy and ecology of Priodontes and Cabassous. Among many other relevant findings, she recently described a new Cabassous species. Teresa was also a key contributor to the National Action Plan for the Conservation of the three-banded armadillo, which aims to reduce the risk of extinction of Tolypeutes tricinctus, with the goal of eventually re-categorizing this species from Endangered to Vulnerable. The plan also seeks to adequately assess the conservation status of Tolypeutes matacus at the national level. Thanks to the efforts of Teresa and others the main conservation guidelines for the preservation of these emblematic species are now in place.

Throughout her years in research, Teresa made every effort to collaborate with other researchers, and often used her own resources to help students who were experiencing financial difficulties. Her career is emblematic of her affection and tireless dedication to academia, having embraced armadillos as the centerpiece of her efforts. Teresa will be deeply missed by all of us.

Flávia R. Miranda, Instituto Tamanduá, Brazil. E-mail: flavia@tamandua.org

\section{FRANÇOIS CATZEFLIS (1953-2021)}

François Catzeflis passed away on November $25^{\text {th }} 2021$ after a one-year battle with cancer.

As a Swiss citizen, François earned his B.S. in Natural Sciences in 1978, M.S. in Biology in 1981, and Ph.D. on the biochemical systematics of shrews in 1984 from the University of Lausanne (Switzerland). Following a post-doctorate at Yale University (USA) under the supervision of the late Prof. Charles G. Sibley, François first came to the University of Montpellier (France) in 1986 as a CNRS research associate at the Institut des Sciences de l'Evolution (ISEM). In 1988, he was appointed a tenured CNRS position as a full time researcher to bring his expertise on DNA-DNA hybridization and apply it to the phylogeny of rodents. At ISEM, where he spent his entire career, he founded the Molecular Phylogeny team and built his own lab in a newly dedicated building. François contributed to the early days of molecular phylogenetics in France by conveying his enthusiasm for molecular systematics, and instilling his typically Helvetic scientific rigor, to his 


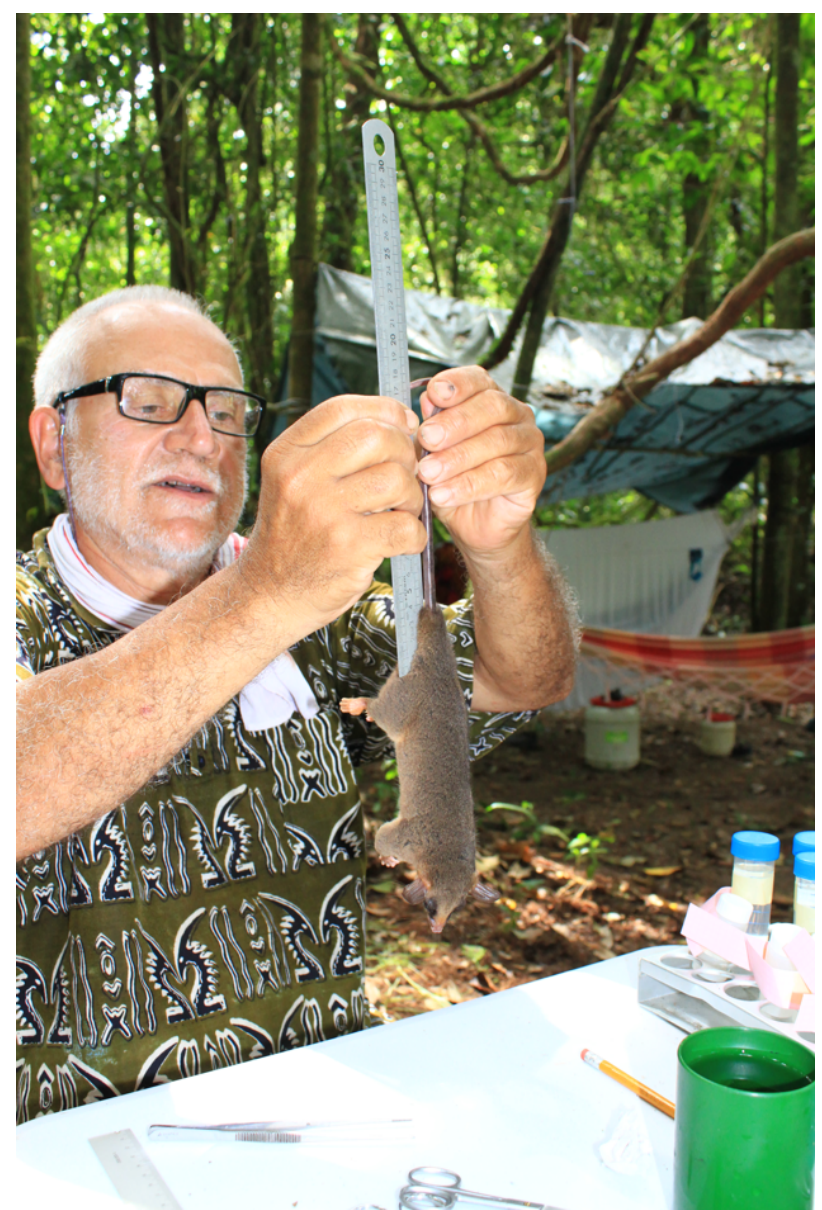

students. He participated actively in the molecular revolution of mammalian phylogeny with the publication of a number of seminal papers in the 1990s and 2000s, notably on the evolutionary relationships of cetartiodactyls, rodents, and xenarthrans. During this time he served as an associate editor for the journal Molecular Phylogenetics and Evolution, and later for Mammalia.

Early on his career, François recognized and advocated the importance of animal tissue collections for DNA analyses in molecular genetics and systematics. However, after a decade of mostly labbased molecular work, François, as a passionate naturalist, started missing fieldwork. He first travelled to French Guiana in 1994 to sample animals, including many armadillos, anteaters and sloths that were rescued during the creation of the Petit-Saut dam on the Sinnamary river, which drowned $200 \mathrm{~km}^{2}$ of pristine Amazonian rainforest. There, he directed the first Ph.D. project on the ecology and population genetics of marsupials, while also discovering the rainforest and its diverse fauna, spending hours, days, and weeks on improbable paths, almost always with his students, and often looking unsuccessfully for a way to get back to the basecamp...

But François literally fell in love with French Guiana, the Amazonian rainforest, and the conservation of its tremendous biodiversity. Making a big change to his career path, he spent the next
20 years conducting numerous fieldwork sessions to study the diversity of small mammals, primarily marsupials, rodents, and bats. He surveyed French Guiana from the most remote, pristine forest areas to coastal savannas, from inselbergs to Amerindian settlements, sharing with equal enthusiasm food rations with the French army, and a traditional fermented cassava drink with Amerindian shamans. His countless efforts resulted in an unprecedented collection of thousands of tissue samples and hundreds of mammal specimens that are now hosted in international museums of natural history, for instance, in Paris and Geneva. François also inspired the creation of the JAGUARS tissue collection (http://kwata.net/la-collection-jaguars-pour-1etude-de-la-biodiversite.html) hosted at the Institut Pasteur de la Guyane, an invaluable resource for genetic studies of mammals in the Guiana Shield.

His fieldwork helped in evaluating the impact of habitat fragmentation by road construction, based on roadkill surveys, the impact of hunting by surveying hunting tables in different local communities, and, thanks to fruitful collaborations with the Institut Pasteur de la Guyane and Cayenne Hospital, the role of small mammals as potential reservoirs of diseases in native Amerindian villages along the Oyapock and Maroni rivers. His work also led to new species discoveries, such as a tiny opossum of the genus Cryptonanus, first observed in barn owl pellets that François meticulously collected and examined. A living specimen was later captured alive in the savannas near the town of Sinnamary. Also, genome-wide species delimitation and morphological analyses recently confirmed a new species of long-nosed armadillo (genus Dasypus) restricted to the Guiana shield, which was initially identified thanks to samples brought back by François from Petit-Saut to Montpellier. Both new species are still in the process of being formally described but François actively contributed to the latest assessment of the IUCN Red List of the vertebrate fauna of French Guiana in 2017, in which they are included. His extensive knowledge went beyond French Guiana borders, with missions and students training in Amapá and Amazonas in Brazil, and in Venezuela. His scientific legacy will last for many years because of the reference xenarthran genomes that have been sequenced from tissues he collected over the years in French Guiana.

Alongside science, François also dedicated time to the public dissemination of scientific knowledge, and his last achievement was the nicely illustrated book Marsupiaux et rongeurs de Guyane, which shed welcome light on this cryptic and so often neglected fauna. In 2005, he extended his research to the French West Indies, and more specifically Martinique, where he significantly contributed to the knowledge and protection of insular mammals 
such as the manikou (Didelphis marsupialis). Finally, in parallel with his scientific career, François was also an avid environmental activist at Greenpeace France, vigorously combating illegal wood importation in France, overfishing in the Mediterranean Sea, and illegal gold mining in French Guiana. He also successfully contested overzealous petrol prospecting and mining projects by national and international corporations in French Guiana. As in science, his commitment to protect the natural environment was truly exemplary and inspirational.

François is survived by his dear wife Chantal and their three children, and his beloved two-year old grandchild Akine. He will be sorely missed by his family, friends, and colleagues.

The picture on the previous page shows François measuring a long-furred woolly mouse opossum (Marmosa demerarae) during one of his last fieldwork sessions in French Guiana, at "savane Roche Annabelle" in 2015. This was a joint small mammals survey with researchers and students from Macapá (Amapá) and Manaus (Amazonas) in Brazil and Institut Pasteur de la Guyane and Kwata NGO in French Guiana.

Frédéric Delsuc, ISEM, Univ. Montpellier, CNRS, IRD, Montpellier, France. E-mail: Frederic.delsuc@umontpellier.fr

Benoit de Thoisy, Institut Pasteur de la Guyane, Cayenne, French Guiana, France and Kwata NGO, Cayenne, French Guiana, France. E-mail: bdethoisy@pasteur-cayenne.fr

\section{UPDATE ON THE PYGMY SLOTH CONSERVATION PROJECT}

The Pygmy Sloth Conservation Project held a workshop called "Key Contributions for the Pygmy Sloth Conservation Plan". It was attended by authorities from the Panamanian Ministry of Environment, members of the communities near Escudo de Veraguas Island, authorities from the Ngäbe-Buglé region, representatives of non-profit organizations, and other governmental institutions.

The overall objective of the workshop was to highlight the importance of pygmy sloth conservation and develop alternative strategies for the integrated management of Escudo de Veraguas Island, based on information provided by key stakeholders in previous workshops. The threats faced by the pygmy sloth were identified and prioritized, alternatives to mitigate these threats were discussed, and key actors were identified to carry out short and long-term actions.

The information generated in this workshop is the first step in the consensual validation process of the Pygmy Sloth Conservation Plan, which will ultimately take into account the perceptions and contributions of the Ngäbe community, other main users of Escudo de Veraguas Island, and the guarantors of the island's conservation. We thank the Zoological Society of London, Disney Conservation Fund, and Nurtured by Nature for their support.

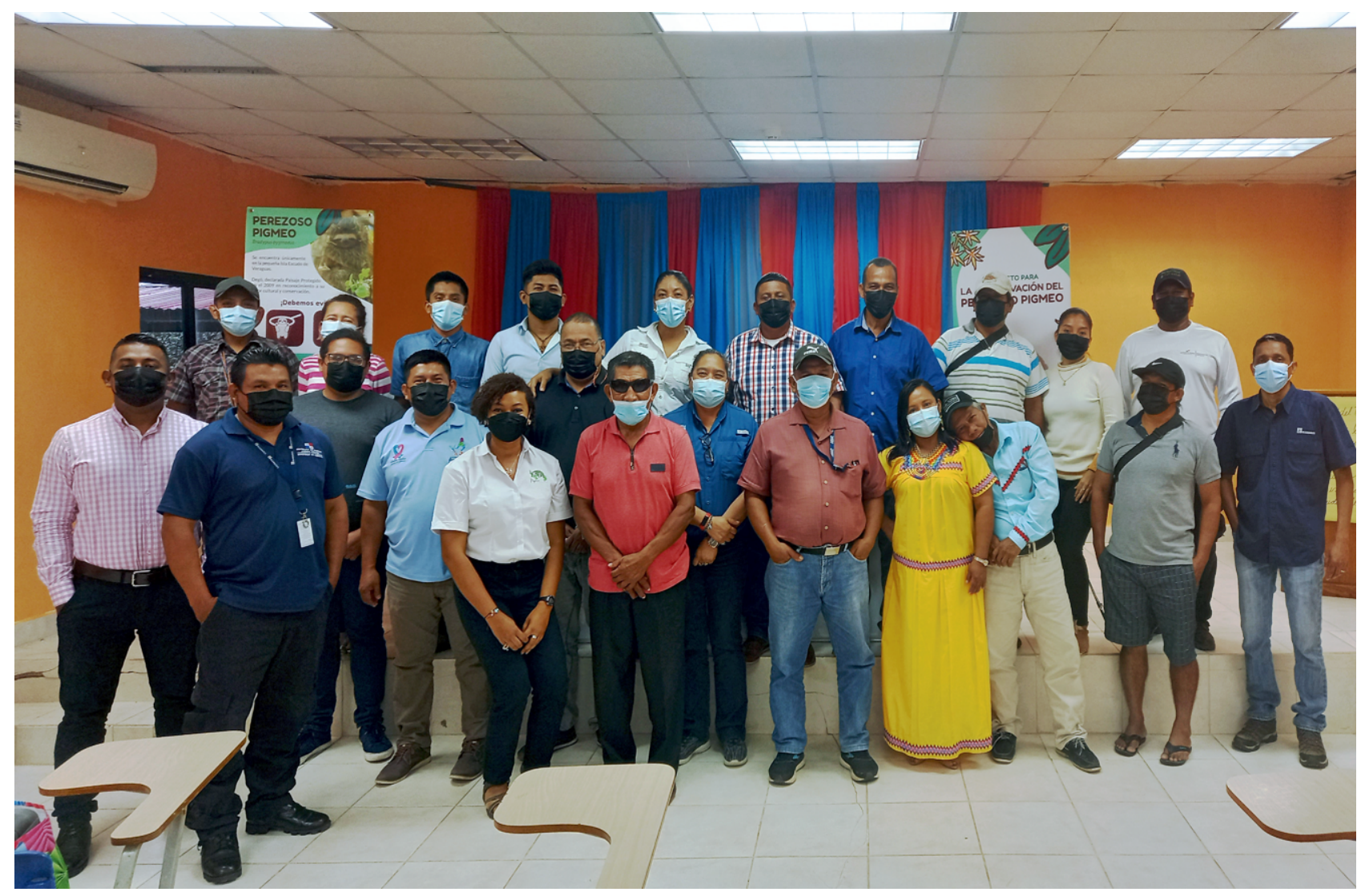




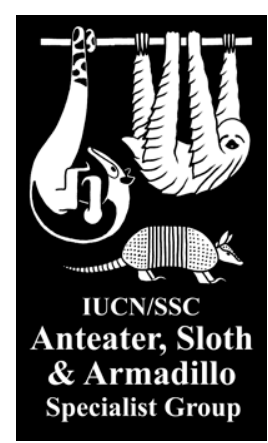




\section{Edentata}

The Newsletter of the IUCN/SSC Anteater, Sloth and Armadillo Specialist Group

December $2021 \bullet$ Number 21

\section{Table of Contents}

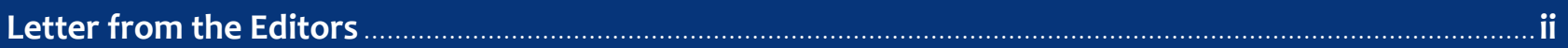

IUCN/SSC Anteater, Sloth and Armadillo Specialist Group Members 2021-2025 ........................................iii

\section{ARTICLES}

Diversity and variation of dorsal carapace structures in the giant armadillo Priodontes maximus (Kerr, 1792) and their potential use for individual identification.

Daniel Barasoain, Pedro Cuaranta \& Romina Adela Mauriño

First estimates of potential lifespan of giant armadillo (Priodontes maximus) in the wild

Arnaud Leonard Jean Desbiez, Duston Larsen, Gabriel Favero Massocato, Nina Attias, Danilo Kluyber \& Damián I. Rumiz

Distribution, ecology, and conservation of Xenarthra in Bolivia — update to 2021 16

Enzo Aliaga-Rossel, Carmen Julia Quiroga, Ximena Velez-Liendo, Alfredo Romero-Muñoz, Zulia Porcel, Robert Benedict Wallace, Guido Marcos Ayala, María Estela Viscarra, Erika Cuéllar Soto, Teresa Tarifa \& Andrew Noss

\section{SHORT COMMUNICATIONS}

Novo registro de Myrmecophaga tridactyla Linnaeus, 1758 (Mammalia: Xenarthra) no estado do Rio Grande do Sul, Brasil.

Karyne Fayes Sharara, Lucas Adriano Pachla, Marthoni Vinicius Massaro \& David Augusto Reynalte-Tataje

First records of the seven-banded armadillo (Dasypus septemcinctus) and the six-banded armadillo (Euphractus sexcinctus) in northwestern Bolivia

Guido Marcos Ayala, María Estela Viscarra \& Robert Benedict Wallace

Primeiro registro de Myrmecophaga tridactyla (Pilosa, Myrmecophagidae) na região norte do Paraná, Brasil.

Marcelo Okamura Arasaki, Alan Deivid Pereira, Marcelo Hideki Shigaki Yabu, Cleber Gustavo de Góes \& Eduardo Issberner Panachão

Record of the silky anteater (Cyclopes didactylus; Xenarthra: Cyclopedidae) in the Atlantic Forest of Rio Grande do Norte state, northeastern Brazil

Paulo Henrique Dantas Marinho, Luiz Yoshihiro Garcia de Lima Hagi, Bruno Rodrigo de Albuquerque França \& Liana Mara Mendes de Sena

News. 